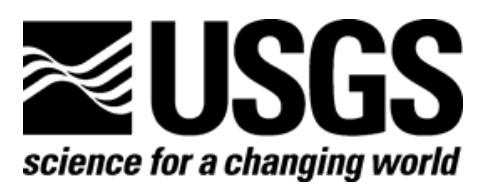

In Cooperation with the North Carolina Geological Survey

\title{
Detailed Sections from Auger Holes in the Roanoke Rapids 1:100,000 Map Sheet, North Carolina
}

By Robert E. Weems and William C. Lewis

Open File Report 2007-1092

U.S. Department of the Interior

U.S. Geological Survey 


\section{U.S. Department of the Interior \\ DIRK KEMPTHORNE, Secretary}

\section{U.S. Geological Survey \\ Mark D. Myers, Director}

\section{U.S. Geological Survey, Reston, Virginia 2007}

For product and ordering information:

World Wide Web: http://www.usgs.gov/pubprod

Telephone: 1-888-ASK-USGS

For more information on the USGS - the Federal source for science about the Earth, its natural and living resources, natural hazards, and the environment:

World Wide Web: http://www.usgs.gov

Telephone: 1-888-ASK-USGS

Suggested citation:

Weems, Robert, and Lewis, William, 2007, Detailed sections from auger holes in the Roanoke Rapids 1:100,000 map sheet, North Carolina: United States Geological Survey Open-File Report 2007-1092, 155 pp.

Any use of trade, product, or firm names is for descriptive purposes only and does not imply endorsement by the U.S. Government.

Although this report is in the public domain, permission must be secured from the individual copyright owners to reproduce any copyrighted material contained within this report. 


\section{Contents}

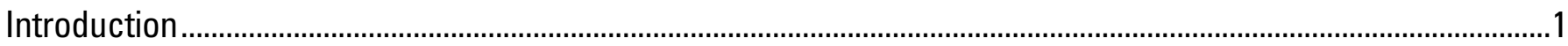

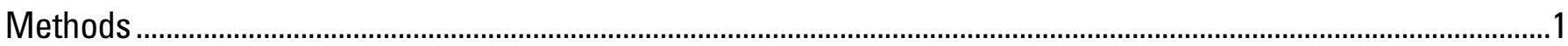

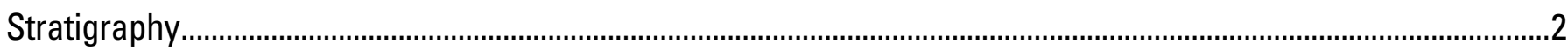

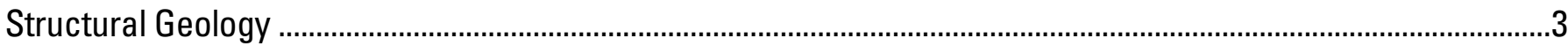

Hydrogeology

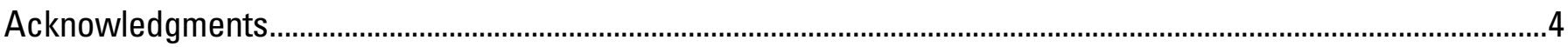

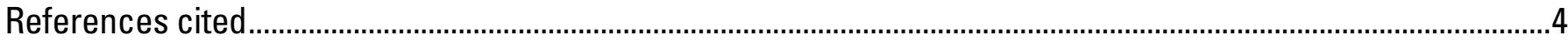

Locality descriptions and detailed lithologic logs:

Aulander quadrangle .................................................................................................................................................

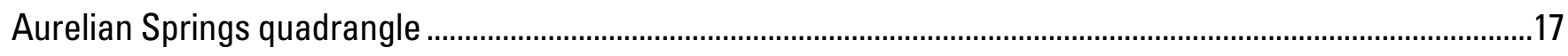

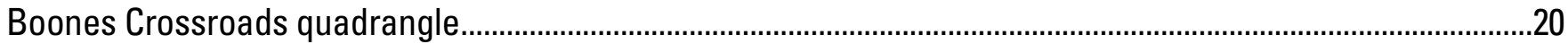

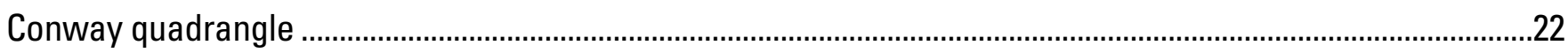

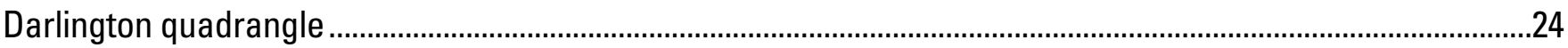

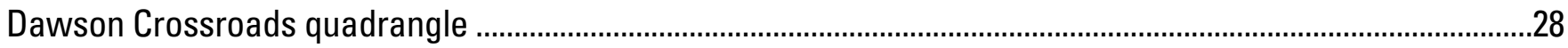

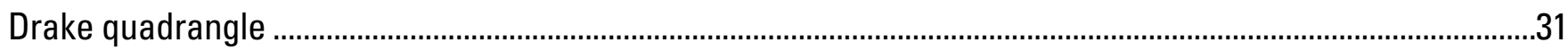

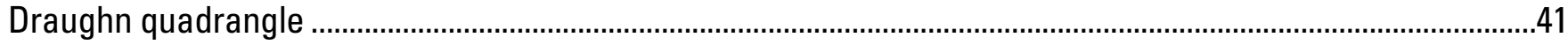

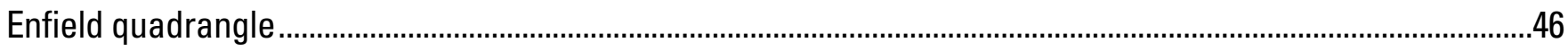

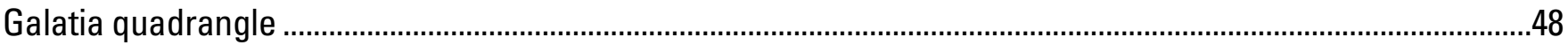

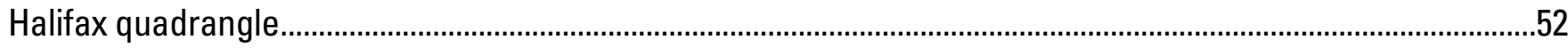

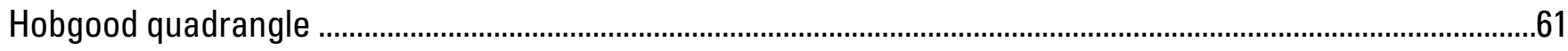

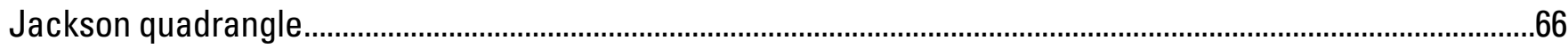

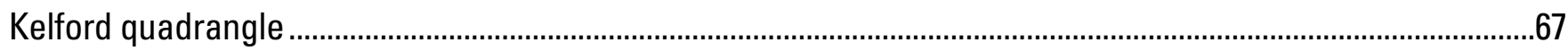

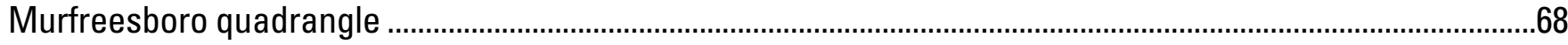

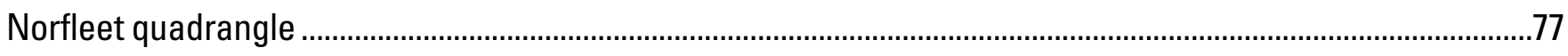

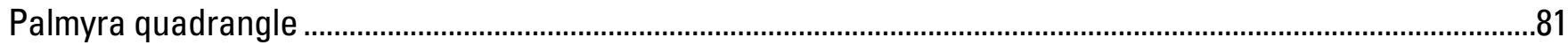

Republican quadrangle ...........................................................................................................................................8

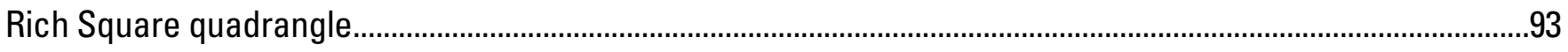

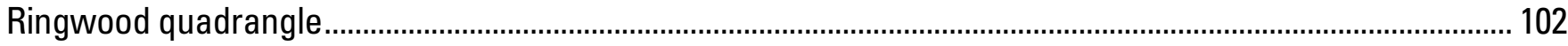




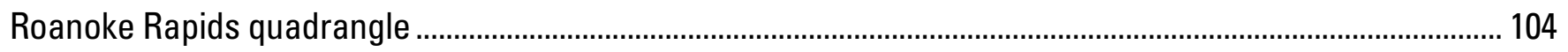

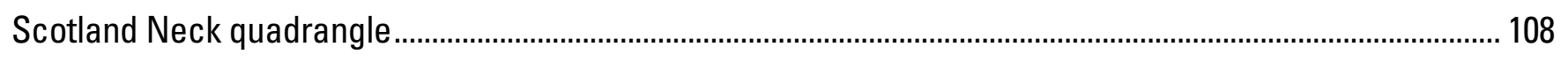

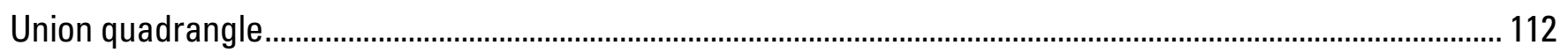

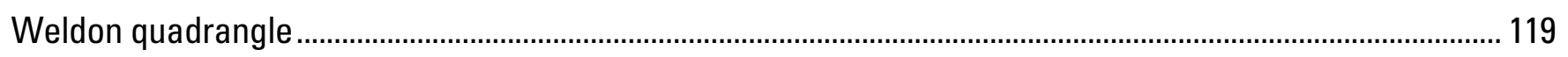

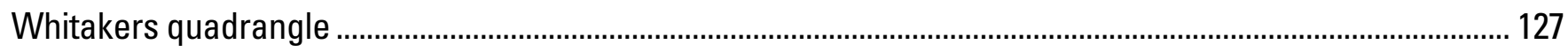

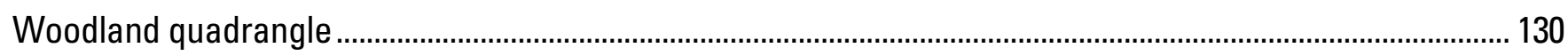

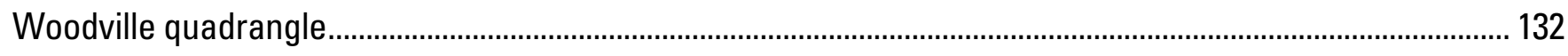

Supplementary Basement Data ............................................................................................................................ 135

\section{Figures}

1. Map of the Roanoke Rapids 1:100,000 scale map region showing area underlain by Atlantic

Coastal Plain sediments, names and locations of constituent 1:24,000 scale topographic

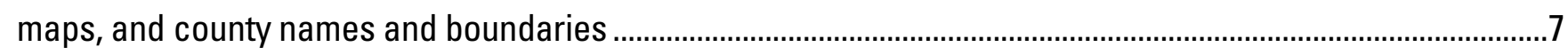

2. Structure contour map of the base of the Coastal Plain in the Roanoke Rapids $1: 100,000$

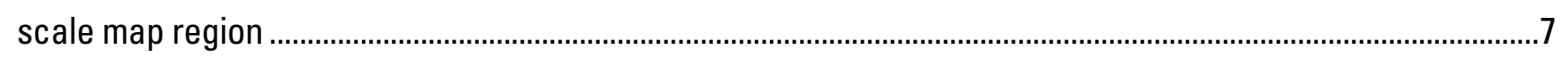

3. Faults and subsurface updip limits of Yorktown and older units.............................................................................

4. Structure contour map of the base of the surficial aquifer in the Roanoke Rapids 1:100,000

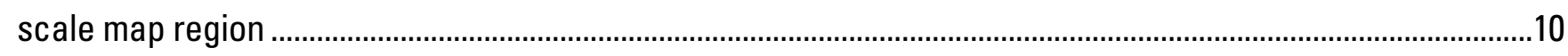

\section{Tables}

1. Age and Sequence of Stratigraphic Units Penetrated during Augering .............................................................11

2. Nomenclature and Maximum Elevation for Terrace Units in Map Area ..............................................................13 


\section{Conversion Factors}

Inch/Pound to SI

\begin{tabular}{lcl}
\hline \multicolumn{1}{c}{ Multiply } & By & \multicolumn{1}{c}{ To obtain } \\
\hline Length & & \\
\hline inch (in.) & 2.54 & centimeter $(\mathrm{cm})$ \\
inch (in.) & 25.4 & millimeter $(\mathrm{mm})$ \\
foot (ft) & 0.3048 & meter $(\mathrm{m})$ \\
mile (mi) & 1.609 & kilometer $(\mathrm{km})$ \\
mile, nautical (nmi) & 1.852 & kilometer $(\mathrm{km})$ \\
yard (yd) & 0.9144 & meter $(\mathrm{m})$ \\
\hline
\end{tabular}

\section{SI to Inch/Pound}

\begin{tabular}{lll}
\hline \multicolumn{1}{c}{ Multiply } & \multicolumn{1}{c}{ By } & \multicolumn{1}{c}{ To obtain } \\
\hline Length & & \\
\hline centimeter $(\mathrm{cm})$ & 0.3937 & inch (in.) \\
millimeter (mm) & 0.03937 & inch (in.) \\
meter (m) & 3.281 & foot (ft) \\
kilometer $(\mathrm{km})$ & 0.6214 & mile (mi) \\
kilometer $(\mathrm{km})$ & 0.5400 & mile, nautical (nmi) \\
meter $(\mathrm{m})$ & 1.094 & yard (yd) \\
\hline
\end{tabular}




\title{
Detailed sections from auger holes in the Roanoke Rapids 1:100,000 map sheet, North Carolina
}

\author{
By Robert E. Weems and William C. Lewis
}

\section{Introduction}

The Roanoke Rapids 1:100,000 map sheet straddles the Coastal Plain / Piedmont boundary in northernmost North Carolina (Figure 1). Sediments of the Coastal Plain underlie the eastern threefourths of this area, and patchy outliers of Coastal Plain units cap many of the higher hills in the western one-fourth of the area. Sediments dip gently to the east and reach a maximum known thickness in the extreme southeast part of the map area (Figure 2). The gentle eastward dip is disrupted in several areas due to faulting.

The U.S. Geological Survey recovered one core and augered 97 research test holes within the Roanoke Rapids 1:100,000 map sheet to supplement sparse outcrop data available from the Coastal Plain portion of the map area. The recovered sediments were studied and data from them recorded to determine the lithologic characteristics, spatial distribution, and temporal framework of the represented Coastal Plain stratigraphic units. These test holes were critical for accurately determining the distribution of major geologic units and the position of unit boundaries that will be shown on the forthcoming Roanoke Rapids geologic map, but much of the detailed subsurface data cannot be shown readily through this map product. Therefore, detailed descriptions have been collected in this open-file report for geologists, hydrologists, engineers, and community planners to provide a detailed shallowsubsurface stratigraphic framework for much of the Roanoke Rapids map region.

\section{Methods}

Surface elevations for each drill site were obtained by hand leveling from a locality of known elevation, commonly a bench mark or spot elevation point on the appropriate 7.5-minute quadrangle. At each test site, lithologic data were gathered by augering with a truck-mounted, Mobile Drill B-40 power auger, using 5-foot drill stem sections. At first, one stem was augered into the ground and pulled to describe the soil profile. Subsequent runs added one, two, or three new stems, depending on depth and on how easily the augering proceeded. For greater accuracy, we attempted to keep sample rise on the drill stems to a minimum.

Along the Tidewater Fall Line, which lies between the Fountain Creek fault and the Thornburg fault in this region (Figure 3), most auger holes targeted the Upper Cretaceous Clubhouse Formation, Cape Fear Formation, or saprolite overlying basement rocks where the Clubhouse and Cape Fear formation were missing. Occasionally at the base of the Coastal Plain section, the drill bit would not penetrate the underlying rock (here termed refusal). Generally, the nature of this rock could be inferred either by small chips on the end of the drill bit or by comparison to nearby outcrops or auger holes.

Lithologic descriptions were made with the aid of a 10X hand lens, grain-size chart, and color charts. Auger sites were plotted on location with 7.5-minute topographic maps. Latitudes and longitudes were established using TopoZone NAD 27 map datum coordinates. 


\section{Stratigraphy}

A full listing of stratigraphic names used here, their ages, and their general lithologic descriptions are given in Table 1. Most geologic names employed here have been used previously in North Carolina, but the name Clubhouse Formation (Gohn, 1992) is extended from South Carolina into this region because the unit here called Clubhouse is lithologically quite similar to the Clubhouse Formation of South Carolina and is the same age. Coastal Plain formational units are bounded by unconformities; formations generally start with a relatively coarse basal lag bed and fine upward. Members within formations, where present, generally represent distinctive lithologic facies that occur within that formation. Surficial stratigraphic units, bounding scarps, and overlying terrace surface names are summarized in Table 2. Unit names mostly conform to those used in this region by Mixon and others (1989) and Ward and Powars (1989) with exceptions discussed in the following paragraphs.

Older coastal plain units, mostly encountered in the subsurface or along valley walls of deeply incised streams, include the Clubhouse Formation (Upper Cretaceous), Cape Fear Formation (Upper Cretaceous), Jericho Run Formation (lower Paleocene; Harris and Law, 1994), Aquia Formation (upper Paleocene), St. Marys Formation (upper Miocene), Eastover Formation (upper Miocene), and the Rushmere and Morgarts Beach members of the Yorktown Formation (upper Pliocene; Zone 2 of Mansfield, 1944). The updip limits of these units in the subsurface are shown in Figure 3.

Surficial stratigraphic units contain very similar facies that formed in fluvial, backbarrier, and sometimes barrier, shoreface, and near-shore depositional environments. These various units, where not heavily eroded, all fine upward to terrace surfaces that have regionally distinctive ranges of elevation. Each of these terrace packages represents an interglacial high stand of sea level. Continuous growth of the East Antarctic ice sheet over the past 2.8 Ma has prevented each successive terrace sequence from reaching the same elevation that it did during the preceding transgression, so successively younger terraces form a downward descending, stair-step sequence of flats separated from each other by scarps that range from pronounced to subtle. Although each sequence is internally similar to the others, older terraces have progressively deeper and more pronounced weathering profiles and show progressively greater erosional degradation. Because each sequence becomes more nearly marine seaward (eastward), each unit shows a gradational shift toward finer lithologies internally, but an abrupt change from finer to coarser when moving from one terrace to the next younger one seaward. All of these criteria have been useful for distinguishing one terrace complex from another.

Surficial units include very high level, fluvial gravels and sands that occur at elevations above 300 feet. These represent the Bon Air gravels of Johnson and others (1987a,b), which are equivalent in age to the Bryn Mawr Formation in Pennsylvania and Maryland (Lewis, 1881) and the Altamaha Formation in Georgia (Dall and Harris, 1892; Huddlestun, 1988) and South Carolina (Fallaw and Price, 1992). Recent mapping to the north of this area (Weems and Edwards, in press) indicates that this unit is late middle Miocene in age and probably represents prograding onshore strata that locally overlie (but regionally are laterally equivalent to) the upper Choptank Formation.

East of the Altamaha outcrop belt, two lithologically distinct sand units overlie the upper Pliocene clay-silt Morgarts Beach Member of the Yorktown Formation. These two terrace units do not have established names in Virginia. The older unit underlies the Richmond Plain (Johnson and others, 1987), but no name has been applied to the plain that caps the younger unit. Therefore, the name "Ashland Plain" is proposed because it is well developed in the vicinity of Ashland, Virginia. The lithologic characteristics of the older unit (a well sorted, heavy mineral-rich sand that underlies the 
plain at elevations of 240 to 270 feet) matches the lithology and stratigraphic position of occasionally fossiliferous marine deposits ascribed to the Duplin Marl just east of the Orangeburg Scarp in South Carolina (Dall, 1898). This unit locally overlies the Morgarts Beach Member of the Yorktown Formation, and thus could represent either a regressive sandy phase of the Rushmere / Morgarts Beach transgressive event, or may be the shoreline deposits of the succeeding Moore House Member of the Yorktown. So far, the proper name for this unit remains enigmatic so it is here simply designated "Yorktown Formation (Zone 3)," adding an additional zone to the two-fold zonation of the Yorktown established by Mansfield (1944). The second unit (a poorly sorted, clayey sand at elevations of 230 to 195 feet), is a northern extension of the Coharrie Formation of North Carolina. In the southeastern part of the Emporia 1:100:00 map sheet, a deep estuary fill underlies this terrace and links it southeastward with sediments in the Chowan River area. Therefore, this terrace unit represents coastal strata of the upper Pliocene Chowan River Formation and is designated by that name.

Terrace deposits between the elevations of 185 and 105 feet previously have been lumped together as the Bacons Castle Formation. There are, however, two distinct units represented within this complex, separated by a scarp at 137 to 147 feet. This scarp has been called the Parler Scarp in South Carolina (Colquhoun, 1965) and the Mechanicsville Scarp in northern South Carolina and southern North Carolina (DuBar and others, 1974). The older name Parler Scarp is used here. The older terrace deposit above the Parler Scarp, here termed "lower Bacons Castle Formation," roughly is equivalent to a unit called the Varina Grove Member of the Bacons Castle Formation by Johnson and others (1987). The younger part of the Bacons Castle, here termed "upper Bacons Castle Formation," includes what has been called the Bahramsville Member and Moorings Unit of the Bacons Castle Formation (Johnson and others, 1987). The Bacons Castle in its type area represents only the upper Bacons Castle Formation. The geomorphic terrace that the lower Bacons Castle Formation underlies has not been separately named, so the name "Essex Plain" is here proposed because it is well developed in Essex County, Virginia. With these exceptions, existing nomenclatural usage is followed here.

In the Roanoke River valley, alluvium occurs beneath two distinctly different terrace surfaces that have been mapped separately. A sample (US 258, Halifax, NC) from the basal sands beneath the higher (older) terrace deposit yielded a quartz blue-light OSL age of 17,200 \pm 780 years BP (one $\sigma$ s.d.) (Shannon A. Mahan, USGS, Denver, written communication). This indicates that this unit is no older than very late Pleistocene. The two terraces represent an earlier high volume flow regime of the Roanoke River and a later lower flow regime. It remains unclear whether the presence of these two distinct terraces resulted from a marked decrease in total annual rainfall volume with the advent of the Holocene in this region, or whether the decrease in maximum water flow resulted from the creation of the extensive series of dams in the upstream portion of the Roanoke drainage basin and the subsequent decrease in the extremes of flooding.

\section{Structural Geology}

Four faults found in the Roanoke Rapids map area have been traced southward from the Emporia map area (Weems and others, in review) (Figure 3). These are the Thornburg fault (and scarp), the Fountains Creek fault, the Stony Creek fault, and the City Point fault. A fifth fault, here named the Palmyra fault, prominently displaces basement and Cretaceous strata. This fault also seems to control the trend of the Roanoke River valley in the southern part of this map area, suggesting much more recent fault movement as well. This fault appears to bound the southwestern margin of the Potomac Group. The other four faults show obvious to subtle effects on younger strata at least as 
young as late Pliocene (zones 2 and 3 of the Yorktown Formation). These effects can be seen readily from the fault-truncated updip limits shown of Figure 3 and the structure contour plot shown on Figure 4.

\section{Hydrogeology}

In the Coastal Plain region, the surficial aquifer in most areas lies on top of the Morgarts Beach Member of the Yorktown Formation (top of Zone 2). In areas where the larger streams have cut down through the Yorktown, the Eastover, Clubhouse, Cape Fear, or crystalline basement may locally define the base of this water body. The surficial aquifer is the main recharge unit for streams and rivers in the eastern three-fourths of the map area, and it is particularly vulnerable to surface pollutants. Deeper wells generally tap aquifer horizons in the Clubhouse or Cape Fear formations. To the west of the Coastal Plain, ground water mostly flows along joints and faults.

\section{Acknowledgments}

The authors would like to thank Lucy E. Edwards and Jean M. Self-Trail for their thorough review of this manuscript.

\section{References Cited}

Brown, P.M., Miller, J.A., and Swain, F.M., 1972, Structural and stratigraphic framework and spatial distribution of permeability of the Atlantic Coastal Plain, North Carolina to New Jersey: U.S. Geological Survey Professional Paper 796, 79 p., 13 figs., 59 pls., 2 tables.

Colquhoun, D.J., 1965, Terrace sediment complexes in central South Carolina: Atlantic Coastal Plain Geological Association, $6^{\text {th }}$ Annual Field Conference Guidebook, 62 p.

Dall, W.H., 1898, A table of the North American Tertiary formations, correlated with one another and with those of western Europe, with annotations: U.S. Geological Survey 18th Annual Report, part 2, p. 323-348.

Dall, W.H., and Harris, G.D., 1892, Correlation papers; Neocene: U.S. Geological Survey Bulletin, 84, $349 \mathrm{p}$.

DuBar, J.R., Johnson, H.S., Jr., Thom, B., and Hatchell, W.O., 1974, Neogene stratigraphy and morphology, south flank of the Cape Fear Arch, North and South Carolina, in Oaks, R.Q., Jr. and DuBar, J.R., Post-Miocene stratigraphy Central and southern Atlantic Coastal Plain: Utah State University Press, Logan, p. 139-173.

Fallaw, W.C., and Price, Van, 1992, Outline of stratigraphy at the Savannah River site, in Fallaw, W.C., and Price, Van, Geological investigations of the central Savannah River area, South 
Carolina and Georgia: Carolina Geological Society Field Trip Guidebook, November 13-15, 1992, no. 22, p. II1-II33.

Gohn, G.S., 1992, Revised nomenclature, definitions, and correlations for the Cretaceous formations in USGS-Clubhouse Crossroads \#1, Dorchester County, South Carolina: U.S. Geological Survey Professional Paper, 1581, 39 p.

Harris, W.B., and Laws, R.A., 1994, Paleogene sediments on the axis of the Cape Fear Arch, Long Bay, North Carolina: Southeastern Geology, vol. 34, no. 4, p. 185-199.

Huddlestun, P.F., 1988, A revision of the lithostratigraphic units of the coastal plain of Georgia; the Miocene through the Holocene: Georgia Geologic Survey Bulletin, no. 104, 162 p.

Johnson, G.H., Goodwin, B.K., Ward, L.W., and Ramsey, K.W., 1987a, Tertiary and Quaternary stratigraphy across the Fall Zone and western Coastal Plain, southern Virginia, in Whittecar, G.R. (ed.), Geological Excursions in Virginia and North Carolina, Southeastern Section: Geological Society of America, 36th Annual Meeting (March 25-27, 1987), Norfolk, Virginia, Old Dominion University, p. 87-144.

Johnson, G.H., Ward, L.W., and Peebles, P.C., 1987b, Stratigraphy and paleontology of Pliocene and Pleistocene deposits of southeastern Virginia, in Whittecar, G.R. (ed.), Geological Excursions in Virginia and North Carolina, Southeastern Section: Geological Society of America, 36th Annual Meeting (March 25-27, 1987), Norfolk, Virginia, Old Dominion University, p. 189-218.

Lewis, H.C., 1881, The Trenton gravel and its relation to the antiquity of man: Proceedings of the Philadelphia Academy of Natural Sciences, vol. 32, p. 258-309.

Mansfield, W.C., 1944, Stratigraphy of the Miocene of Virginia and the Miocene and Pliocene of North Carolina, in Gardner, J., Mollusca from the Miocene and lower Pliocene of Virginia and North Carolina: United States Geological Survey Professional Paper 199-A, p. 1-16.

Mixon, R.B., Berquist, C.R., Jr., Newell, W.L., Johnson, G.H., Powars, D.S., Schindler, J.S., and Rader, E.K., 1989, Geologic map of the Coastal Plain and adjacent parts of the Piedmont, Virginia with generalized geologic cross sections: U.S. Geological Survey Miscellaneous Investigations Map I-2033, scale 1:250,000.

Trapp, Henry, Jr., 1992, Hydrogeologic framework of the northern Atlantic Coastal Plain in parts of North Carolina, Virginia, Maryland, Delaware, New Jersey, and New York: U.S. Geological Survey Professional Paper 1404-G, p. G1-G59.

Ward, L.W., and Powars, D.S., 1989, Tertiary stratigraphy and paleontology, Chesapeake Bay Region, Virginia and Maryland: International Geological Congress Field Trip T-216 (July 15-17, 1989), American Geophysical Union, 64 p.

Weems, R.E., and Edwards, L.E., in press, Evidence for a late middle Miocene (13-14 Ma) marine transgression across the eastern Piedmont of central Virginia: Stratigraphy. 
Weems, R.E., Schindler, J.S., and Lewis, W.C., in review, Detailed sections from auger holes in the Emporia 1:100,000 map sheet, North Carolina and Virginia: U.S. Geological Survey Open-File Report. 
Figure 1. Map of the Roanoke Rapids 1:100,000 scale map region, showing area underlain by Atlantic Coastal Plain sediments (white), names and locations of constituent 1:24,000 scale topographic maps, and county names and boundaries. Small circles indicate auger hole locations; gray area to west is the Roanoke Rapids terrane of the Piedmont Province.

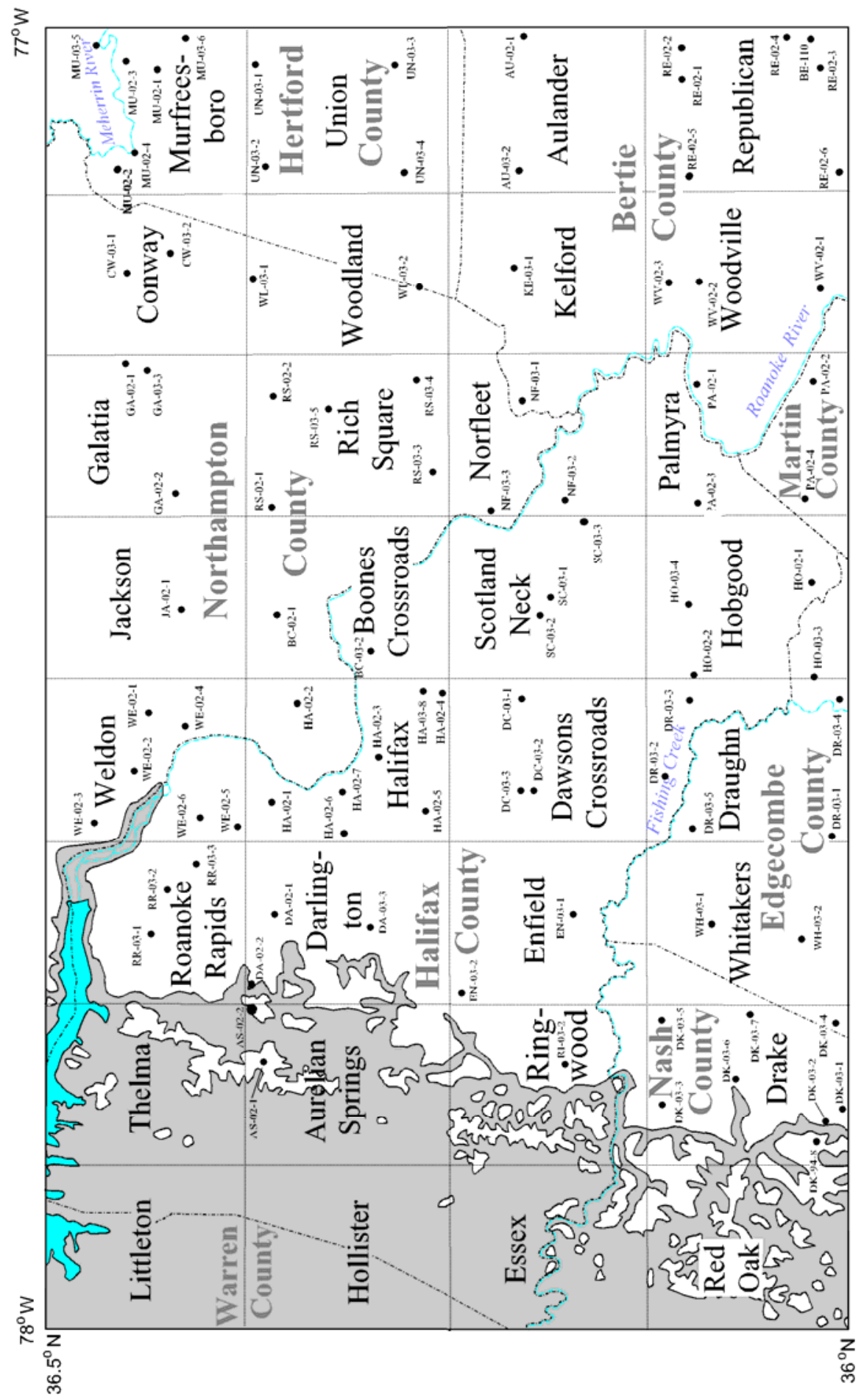


Figure 2. Structure contour map of the base of the Coastal Plain in the Roanoke Rapids 1:100,000 scale map region, showing areas where basement is overlain by Cretaceous sediments (white) and middle Miocene or younger sediments (light gray). Piedmont region is dark gray; contour interval is 100 feet. Faults indicated by heavy dashed lines with $\mathrm{U}$ for upthrown and $\mathrm{D}$ for downthrown side. Black circles denote basement control points, and black triangles denote places where Cretaceous deposits were encountered but Cretaceous thickness is unknown. Negative values are below sea level.

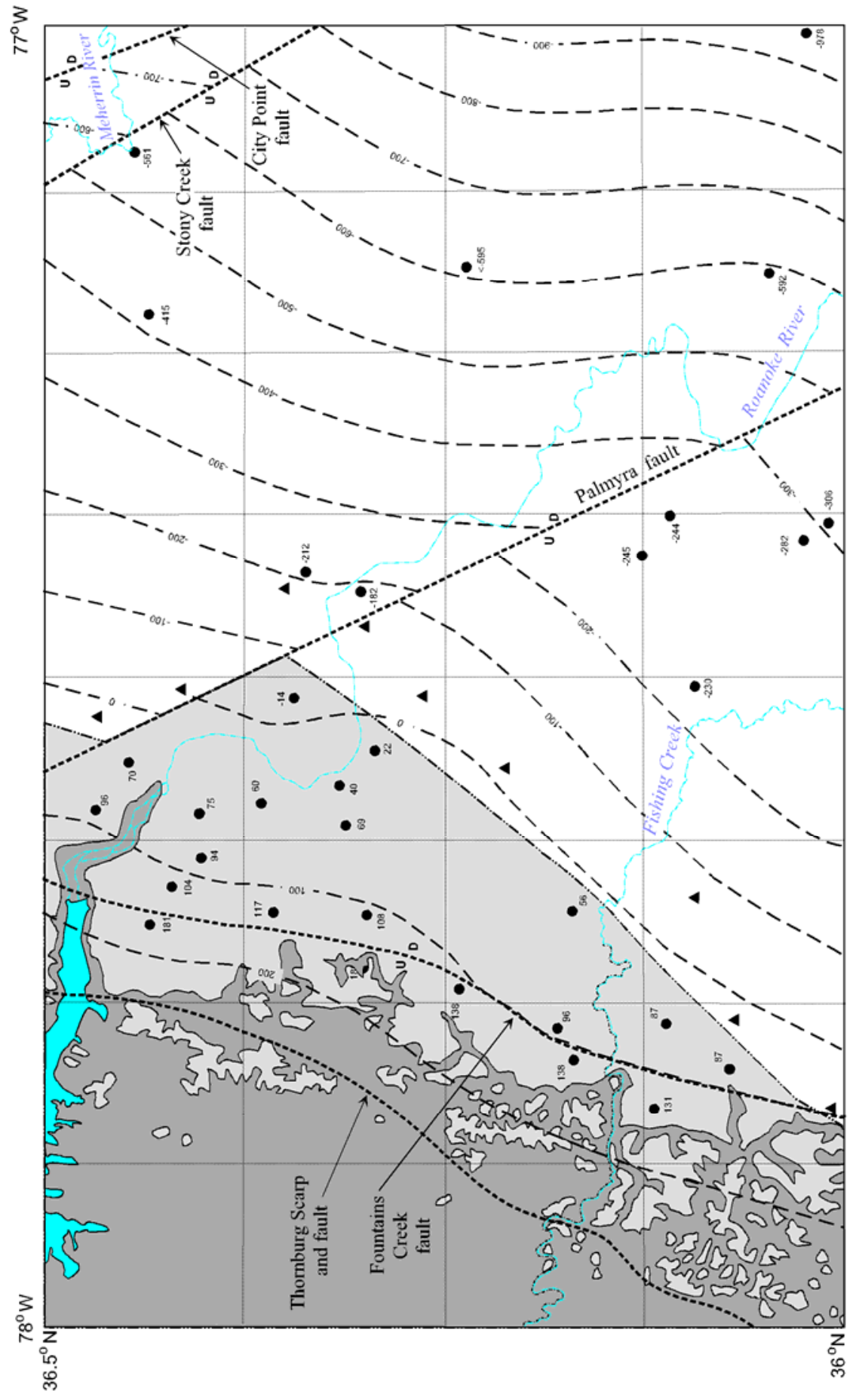


Figure 3. Faults and subsurface updip limits of Yorktown and older units. One outlier of the Eastover Formation is labeled. Circles and labels denote localities of subsurface control points described in auger log and supplementary data sections.

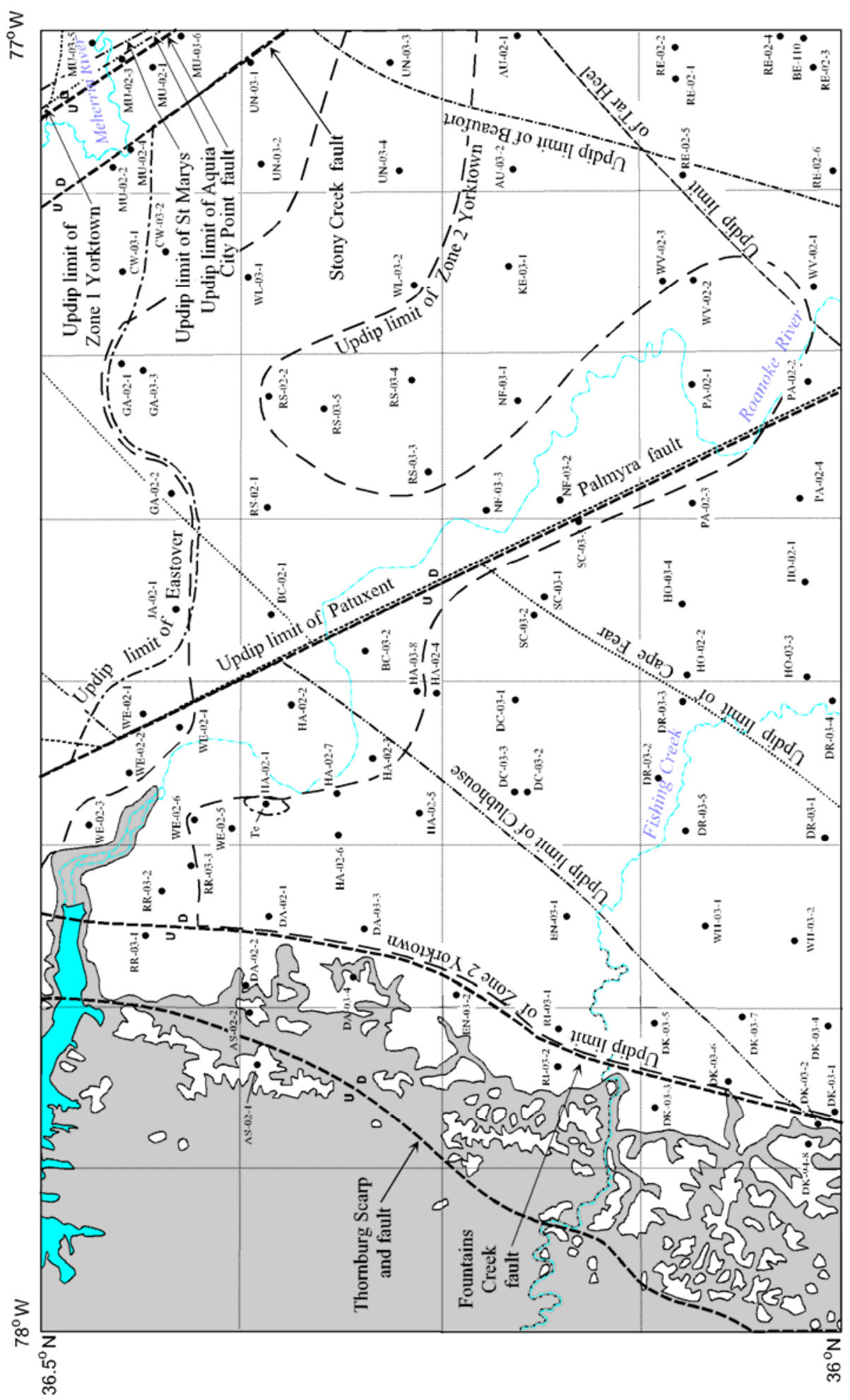


Figure 4. Structure contour map of the base of the surficial aquifer in the Roanoke Rapids 1:100,000 scale map region. Subsurface control points are shown as black circles with elevations indicated next to them; outcrop data points are shown as white circles. In most of the region, the shallow aquifer immediately overlies Zone 2 of the Yorktown. Piedmont region is dark gray; contour interval is 20 feet. Faults indicated by heavy dashed lines with $\mathrm{U}$ for upthrown side and $\mathrm{D}$ for downthrown side.

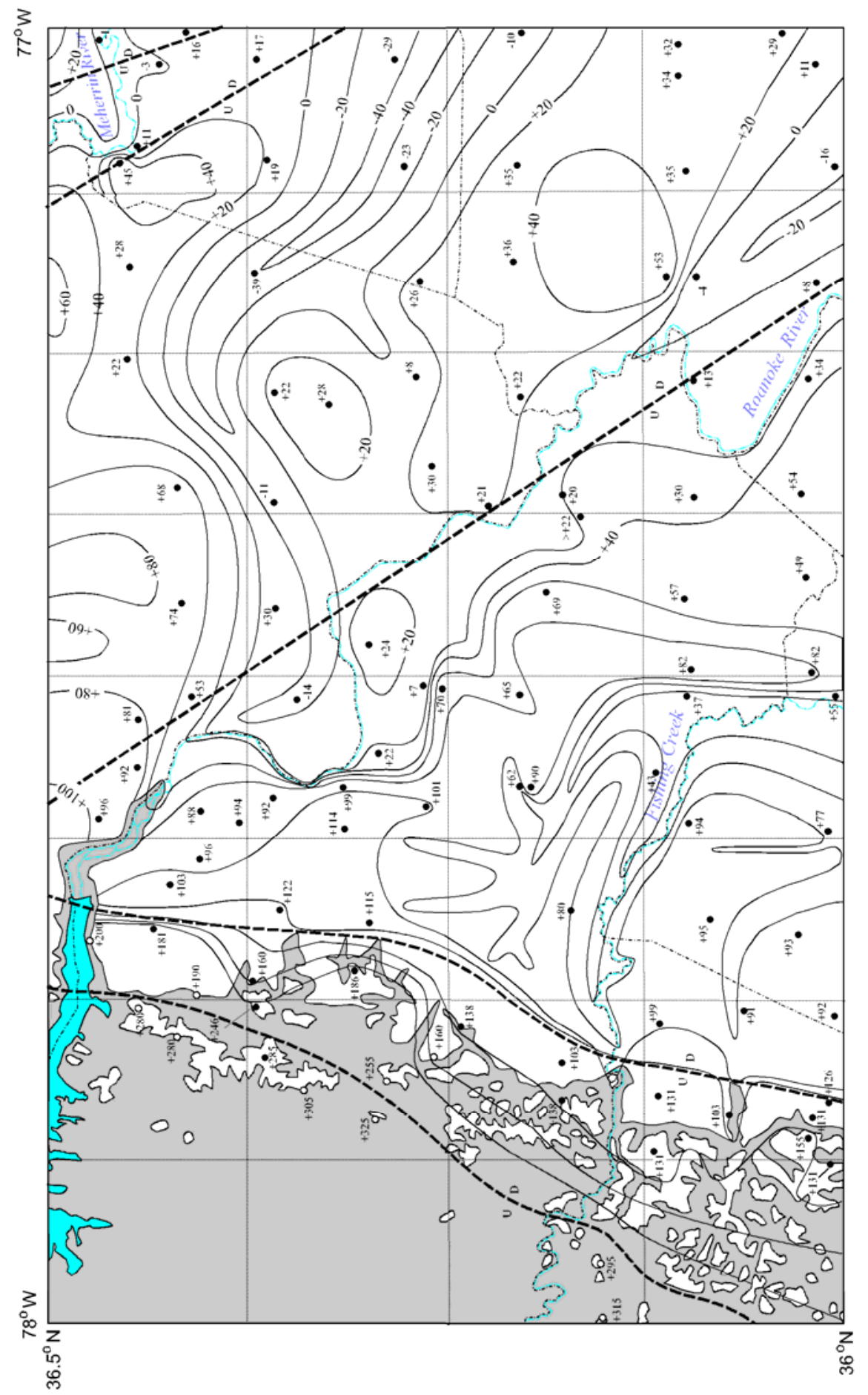


Table 1. Age and relative position of stratigraphic units in map area.

\begin{tabular}{|c|c|c|}
\hline Unit & Lithology & Age \\
\hline Artificial Fill & Materials variable & HOLOCENE \\
\hline Alluvium & $\begin{array}{l}\text { Fine to coarse quartz sand; } \\
\text { silty or clayey; pebbly }\end{array}$ & $\begin{array}{l}\text { HOLOCENE AND } \\
\text { PLEISTOCENE? }\end{array}$ \\
\hline Older alluvium & $\begin{array}{l}\text { Fine to coarse quartz sand; } \\
\text { silty or clayey; to gravel }\end{array}$ & $\begin{array}{l}\text { HOLOCENE? AND } \\
\text { PLEISTOCENE }\end{array}$ \\
\hline Tabb Formation & $\begin{array}{l}\text { Fine to coarse quartz sand; } \\
\text { poorly sorted; clayey }\end{array}$ & PLEISTOCENE \\
\hline Shirley Formation & $\begin{array}{l}\text { Fine to coarse quartz sand; } \\
\text { poorly sorted; clayey }\end{array}$ & PLEISTOCENE \\
\hline $\begin{array}{l}\text { Chuckatuck Formation, } \\
\text { barrier sand facies }\end{array}$ & $\begin{array}{l}\text { Fine to medium quartz sand; } \\
\text { well sorted, clean }\end{array}$ & PLEISTOCENE \\
\hline $\begin{array}{l}\text { Chuckatuck Formation, } \\
\text { back barrier facies }\end{array}$ & $\begin{array}{l}\text { Fine to coarse quartz sand; } \\
\text { poorly sorted; clayey }\end{array}$ & PLEISTOCENE \\
\hline Charles City Formation & $\begin{array}{l}\text { Fine to coarse quartz sand; } \\
\text { poorly sorted; clayey }\end{array}$ & PLEISTOCENE \\
\hline Windsor Formation & $\begin{array}{l}\text { Fine to coarse quartz sand; } \\
\text { poorly sorted; locally gravelly }\end{array}$ & PLEISTOCENE \\
\hline $\begin{array}{l}\text { Upper Bacons Castle Fm., } \\
\text { Moorings Unit }\end{array}$ & $\begin{array}{l}\text { Fine to medium quartz } \\
\text { sand; well sorted }\end{array}$ & PLEISTOCENE \\
\hline $\begin{array}{l}\text { Upper Bacons Castle Fm., } \\
\text { Bahramsville Member }\end{array}$ & $\begin{array}{l}\text { Fine to coarse quartz sand; } \\
\text { poorly sorted; muddy, gravelly }\end{array}$ & PLEISTOCENE \\
\hline $\begin{array}{l}\text { Lower Bacons Castle Fm., } \\
\text { Varina Grove Member }\end{array}$ & $\begin{array}{l}\text { Fine to coarse quartz sand; } \\
\text { poorly sorted; muddy, gravelly }\end{array}$ & PLIOCENE \\
\hline Chowan River Formation & $\begin{array}{l}\text { Fine to coarse quartz sand; } \\
\text { poorly sorted; clayey, silty }\end{array}$ & PLIOCENE \\
\hline \multicolumn{3}{|l|}{ Yorktown Formation: } \\
\hline $\begin{array}{l}\text { Moorehouse Member? } \\
\quad \text { (Zone 3) }\end{array}$ & $\begin{array}{l}\text { Fine to coarse quartz sand; } \\
\text { heavy minerals often abundant }\end{array}$ & PLIOCENE \\
\hline $\begin{array}{l}\text { Morgarts Beach Member } \\
\text { (Zone 2) }\end{array}$ & $\begin{array}{l}\text { Silt to very fine quartz sand, } \\
\text { silty and clayey, fossiliferous }\end{array}$ & PLIOCENE \\
\hline $\begin{array}{l}\text { Rushmere Member } \\
\text { (Zone 2) }\end{array}$ & $\begin{array}{l}\text { Medium to very coarse sand, sparsely to } \\
\text { abundantly shelly; locally pebble to cobble gravel }\end{array}$ & PLIOCENE \\
\hline Eastover Formation & $\begin{array}{l}\text { Fine to medium quartz sand, well sorted, } \\
\text { glauconitic, shelly }\end{array}$ & UPPER MIOCENE \\
\hline St. Marys Formation & Clayey silt to silt, dense, sticky & UPPER MIOCENE \\
\hline
\end{tabular}


Altamaha Formation

Choptank Formation

Aquia Formation

Jericho Run Formation

Tar Heel Formation

Cape Fear Formation

Clubhouse Formation

Patuxent Formation ${ }^{1}$

Chatham Group ${ }^{1}$

(undifferentiated)

Eastern Carolina Slate Belt:

Metamorphosed Granite

Felsic Slate Belt Rocks
Fine to coarse clayey quartz sand; poorly sorted; gravelly, most clasts soft and rotten

Fine to medium silty sand, well sorted

Fine to medium silty sand, glauconitic, contains scattered round quartz granules

Fine to coarse quartz sand, poorly sorted, glauconitic

Sand, silty and clayey, pyritic, lignitic, dense

Sand, silty and clayey, dense, varicolored

Silt, clayey, very fine sandy, dense, varicolored, interbedded with fine to medium quartz sand and dense varicolored clays

Fine to very coarse feldspathic quartz sand; pebbly, rare clay lenses

Pebble to cobble conglomerate interbedded with sandstone and siltstone, tightly cemented

Medium grained granite, strongly foliated, weathering to subangular to subround quartz-rich saprolite

Fine to medium feldspar- rich schists and gneisses, weathering to banded clays
MIDDLE MIOCENE

MIDDLE MIOCENE

UPPER PALEOCENE

LOWER PALEOCENE

UPPER CRETACEOUS

UPPER CRETACEOUS

UPPER CRETACEOUS

LOWER CRETACEOUS

UPPER TRIASSIC

LOWER PALEOZOIC?

CAMBRIAN AND/OR NEOPROTEROZOIC

${ }^{1}$ Within map area, but not augered 
Table 2. Nomenclature and Maximum Elevation for Terrace Units in Map Area.

\begin{tabular}{|c|c|c|c|}
\hline Unit & Overlying Surface & Maximum Elevation & Intervening Scarp \\
\hline \multirow[t]{2}{*}{ Altamaha Formation } & Midlothian Uplands & 410 feet & \\
\hline & & & Thornburg Scarp \\
\hline \multirow[t]{2}{*}{ Yorktown Fm. (Zone 3) } & Richmond Plain & 275 feet & \\
\hline & & & Chippenham Scarp \\
\hline \multirow[t]{2}{*}{ Chowan River Formation } & Ashland Plain ${ }^{1}$ & 235 feet & \\
\hline & & & Broad Rock Scarp \\
\hline \multirow[t]{2}{*}{ Lower Bacons Castle Fm. } & Essex Plain ${ }^{1}$ & 182 feet & \\
\hline & & & Parler Scarp \\
\hline \multirow[t]{2}{*}{ Upper Bacons Castle Fm. } & Norge Uplands & 137 feet & \\
\hline & & & Surry Scarp \\
\hline \multirow[t]{2}{*}{ Windsor Formation } & Lackey Plain & 105 feet & \\
\hline & & & Ruthville Scarp \\
\hline \multirow[t]{2}{*}{ Charles City Formation } & Grove Plain & 80 feet & \\
\hline & & & Lee Hall Scarp \\
\hline \multirow[t]{2}{*}{ Chuckatuck Formation } & Grafton Plain & 62 feet & \\
\hline & & & Kings Mill Scarp \\
\hline \multirow[t]{2}{*}{ Shirley Formation } & Huntington Flat & 49 feet & \\
\hline & & & Suffolk Scarp \\
\hline Tabb Formation & Todds Flat & 26 feet & \\
\hline
\end{tabular}

${ }^{1}$ New name 


\section{Locality Descriptions and Detailed Lithologic Logs}

\section{AULANDER QUADRANGLE}

AU-02-1: 0.25 mile west of the east quadrangle border, 5.5 miles north of south quadrangle border, in east-central $1 / 9^{\text {th }}$ of map area (latitude $36.2046^{\circ} \mathrm{N}$, longitude $77.0039^{\circ} \mathrm{W}$ ). Surface elevation 42 feet.

\section{LITHOLOGY}

DEPTH IN FEET

\section{Chuckatuck Formation}

Silt, very fine sandy, slightly clayey, dark yellowish orange (10YR 6/6) mottled yellowish gray $(5 Y 7 / 2)$ $0-2$

Silt, clayey, very fine sandy, dense, stiff, light yellowish gray $(5 Y 8 / 2)$ mottled dusky yellow (5Y 6/4) and greenish gray $(5 G 6 / 1)$ grading down to greenish gray $(5 G 6 / 1)$ mottled light yellowish gray $(5 Y 8 / 2)$ and dusky yellow $(5 Y 6 / 4)$ $2-12$

\section{Charles City Formation?}

Sand, very fine to fine, silty, greenish gray $(5 G Y 6 / 1)$, much softer than above, grades to $12-28$

Sand, fine to medium, silty, slightly to moderately micaceous, contains $1-2 \%$ dark heavy minerals, thixotropic, greenish gray $(5 G Y 6 / 1)$, grades to $.28-49$

Sand, medium to coarse, contains scattered round quartz pebbles up to $0.5 \mathrm{~cm}$ in diameter, greenish gray $(5 G Y 6 / 1)$ $49-52$

\section{Yorktown Formation (Zone 2)}

Sand, very fine to fine, silty, very micaceous, stiffer than above, greenish gray $(5 G Y 6 / 1)$, grades to $52-62$

Silt, very fine sandy, clayey, sticky, medium greenish gray $(5 G 5 / 1)$, sparse round quartz pebbles at base up to $0.5 \mathrm{~cm}$ in diameter $.62-77$

\section{Jericho Run Formation}

Sand, fine to medium, silty, clayey, dense, indurated at top, olive black $(5 Y 2 / 1)$ $.77-81$ 
Base of Chuckatuck Formation: +30 feet elevation

Base of Charles City Formation?: $\quad-10$ feet elevation

Base of Yorktown Formation (Zone 2): $\quad-35$ feet elevation

Bottomed in Jericho Run Formation 
AU-03-2: 5.9 miles west of the east quadrangle border, 5.65 miles north of south quadrangle border, in west-central $1 / 9^{\text {th }}$ of map area (latitude $36.2065^{\circ} \mathrm{N}$, longitude $77.1045^{\circ} \mathrm{W}$ ). Surface elevation about 70 feet.

\section{LITHOLOGY}

DEPTH IN FEET

\section{Chuckatuck Formation}

Sand, dominantly fine with sparse medium, silty, clayey, very pale brown $(5 Y R 6 / 2)$. $0-1$

Sand, fine to coarse, subangular, silty, clayey, stiff, dark yellowish orange (10YR 6/6) (1-2 feet) grading through pale olive gray (5Y 7/1) mottled medium brownish gray $(5 Y R 5 / 1)$ and dark yellowish brown $(10 Y R$ 4/6) (2-3 feet) to pale olive gray $(5 Y 6 / 2)$. $1-6$

Sand, fine to medium grading down to fine, silty, clayey, pale olive gray $(5 Y 6 / 2)$ $6-7$

Sand, very fine, silty, clayey, light greenish gray $(5 G Y 7 / 1)$ $.7-11$

Sand, medium to very coarse, subangular, silty, sparse round quartz pebbles up to $1 \mathrm{~cm}$ in diameter at base, yellowish gray $(5 Y 7 / 2)$ (11-18 feet) grading through pale olive gray (5Y 7/1) (18-30 feet) to olive gray $(5 Y 4 / 1)$ $.11-35$

\section{Yorktown Formation (Zone 2)}

Sand, very fine grading down to very fine to fine, silty, clayey, dark greenish gray $(5 G Y 4 / 1)$ grading down to medium greenish gray $(5 G Y 5 / 1)$ $35-86$

Sand, fine to medium, round quartz pebbles and subdiscoids up to $3 \mathrm{~cm}$ in diameter common, fine to medium grained sandstone clast

$3 \mathrm{~cm}$ in length also present, medium greenish gray $(5 G Y 5 / 1)$. $.86-88$

\section{Indeterminate Formation}

Impenetrable hard bed. at 88

$\begin{array}{ll}\text { Base of Chuckatuck Formation: } & +35 \text { feet elevation } \\ \text { Base of Yorktown Formation (Zone 2): } & -18 \text { feet elevation }\end{array}$

Bottomed on Tar Heel Formation? 


\section{AURELIAN SPRINGS QUADRANGLE}

AS-02-1: 2.43 miles west of the east quadrangle border, 7.79 miles north of the south quadrangle border, in north-central $1 / 9^{\text {th }}$ of map area (latitude $36.3630^{\circ} \mathrm{N}$, longitude $77.7936^{\circ} \mathrm{W}$ ). Surface elevation 355 feet.

\section{LITHOLOGY}

DEPTH IN FEET

\section{Altamaha Formation}

Sand, fine to coarse, silty, clayey, contains sparse round quartz pebbles up to $4 \mathrm{~cm}$ in diameter, dark grayish orange $(10 Y R 6 / 4)$ $0-9$

Sand, fine to coarse, silty, more clayey than above, grayish orange (10YR 6/4) mottled light gray (N 7.5) $9-12$

Sand, fine to coarse, silty, less clayey than above, moderate red ( $5 R 5 / 4)$ grading down to light gray $(N 7.5)$ $12-16$

Sand, fine to coarse, clayey, silty, tough, moderate red (5R 5/4) and light gray $(N 7.5)$ interlayered. $16-21$

Sand, fine to coarse, clayey, silty, tough, moderate red (5R 5/4) mottled light gray $(N 7.5)$ $.21-26$

Sand, fine to coarse, clayey, silty, pebbly, very fine to fine dark heavy minerals abundant, light red ( $5 R 6 / 4)$ grading down to light gray $(N 7.5)$ streaked with light red $(5 R 6 / 4)$ $26-34$

Sand, fine to coarse, clayey, silty, pebbly, pebbles abundant at base, light red $(5 R 6 / 4)$ $.34-49$

Gravel, clayballs, sand matrix poorly sorted but well rounded, light gray $(N 7.5)$ $49-50$

\section{Choptank Formation}

Sand, fine to medium, well sorted, silty, softer than above, light yellowish orange $(10 Y R 7 / 6)$ $.50-51$ 
Sand, fine to medium grading down to very fine to fine, more silty than above, micaceous, contains scattered medium to coarse subround to round quartz grains, light yellowish orange (10YR 7/6)

$.51-69$

Sand, fine to medium, contains round quartz pebbles up to $1 \mathrm{~cm}$ in diameter, light yellowish orange (10YR 7/6) $69-70$

\section{Eastern Carolina Slate Belt rocks}

Sand, very fine to fine, clayey, dense, dark grayish yellow green $(5 G Y 6 / 2)$...................70 - 71

Base of Altamaha Formation: $\quad+305$ feet elevation

Base of Choptank Formation: $\quad+285$ feet elevation

Bottomed in Eastern Carolina Slate Belt rocks 
AS-02-2: 0.08 mile west of the east quadrangle border, 8.47 miles north of the south quadrangle border, in northeast $1 / 9^{\text {th }}$ of map area (latitude $36.3728^{\circ} \mathrm{N}$, longitude $77.7512^{\circ} \mathrm{W}$ ). Surface elevation 265 feet.

\section{LITHOLOGY}

DEPTH IN FEET

\section{Yorktown Formation (Zone 3)}

Sand, fine to coarse, silty, clayey, contains subround to round quartz pebbles up to $1 \mathrm{~cm}$ in diameter, moderate brown $(5 Y R$ 4/4) grading down to moderate brown $(5 Y R 4 / 6)$ $0-1$

Sand, fine to coarse grading down to fine, silty, clayey, micaceous, very fine to fine dark heavy mineral grains abundant, moderate brown $(5 Y R 4 / 6)$ $1-11$

Sand, fine to medium, slightly silty, very fine to fine, dark heavy mineral grains abundant, moderate brown $(5 Y R 4 / 6)$ $11-18$

Sand, fine to coarse, subround quartz pebbles and subdiscoids present up to $6 \mathrm{~cm}$ in diameter, fine to medium dark heavy mineral grains abundant, moderate yellowish orange $(10 Y R 7 / 6)$ $18-19$

Sand, fine, well-sorted, very fine dark heavy mineral grains abundant, slightly silty, moderate yellowish orange (10YR 7/6). $19-23$

Sand, very fine, silty, very fine dark heavy mineral grains abundant, moderate yellowish orange (10YR 7/6) $23-26$

Silt, very fine sandy, light reddish brown $(10 R 4 / 4)$ $.26-31$

Gravel, round to subround quartz clasts up to $5 \mathrm{~cm}$ in diameter, very fine sandy silt matrix, light reddish brown (10R 4/4) $31-34$

\section{Eastern Carolina Slate Belt Rocks}

Saprolite, angular gray quartz grains in clay-silt matrix, light reddish brown $(10 R 4 / 4)$ and light gray $(N 8)$ with a salt and pepper texture that may reflect ghosts of feldspar and amphibole respectively . $34-36$

Base of Yorktown Formation (Zone 3): +231 feet elevation

Bottomed in Eastern Carolina Slate Belt rocks 


\section{BOONES CROSSROADS OUADRANGLE}

BC-02-1: 4.10 miles west of the east quadrangle border, 7.41 miles north of the south quadrangle border, in north-central $1 / 9^{\text {th }}$ of map area (latitude $36.3576^{\circ} \mathrm{N}$, longitude $77.4483^{\circ} \mathrm{W}$ ). Surface elevation 88 feet.

\section{LITHOLOGY}

DEPTH IN FEET

\section{Windsor Formation}

Sand, fine, well sorted, silty, slightly clayey, pale yellowish brown $(10 Y R 6 / 2)$ grading down to dark yellowish orange $(10 Y R 6 / 6)$ $0-1$

Sand, fine, well sorted, silty, slightly clayey, reddish brown $(10 R 4 / 6)$ mottled yellowish gray $(5 Y 7 / 2)$ grading down to dark yellowish orange $(10 Y R 6 / 6)$, grades rapidly to $1-6$

Sand, medium to coarse, subangular to subround, silty and slightly clayey, dark yellowish orange (10YR 6/6), grades rapidly to $6-13$

Silt, slightly clayey and very fine sandy, contains scattered grains of medium sand, dark yellowish orange (10YR 6/6) streaked yellowish gray ( $5 Y 7 / 2)$; sand disappears by 21 feet and silt contains very fine to fine flakes of silvery mica, grades rapidly at base to $13-30$

Sand, fine, well sorted, silty, contains coarse flakes of silvery mica, dark yellowish orange $(10 Y R 6 / 6)$, grades to $.30-40$

Sand, very fine to fine, clayey, silty, moderate grayish yellow (5Y 7/4) $.40-46$

Sand, fine to medium grading downward to fine to coarse, silty, soft, feldspathic, sparse very fine to fine dark heavy minerals present, moderate grayish orange (10YR 8/4). $46-56$

Sand, fine to coarse, feldspathic, gravelly with subangular to subround quartz clasts up to $5 \mathrm{~cm}$ in diameter, olive $(10 Y 5 / 2)$. $.56-58$

\section{Clubhouse Formation}

Silt, clayey, very fine sandy, interbedded with sand, very fine, silty and clayey, dense and stiff, micaceous, medium greenish gray $(5 G 5 / 1)$ grading by 61 feet to dark reddish brown $(10 R 3 / 6)$ mottled pale olive gray $(5 Y 6 / 2)$ $58-71$

Base of Windsor Formation: +30 feet elevation

Bottomed in Clubhouse Formation 
BC-03-2: 5.71 miles west of the east quadrangle border, 3.39 miles north of the south quadrangle border, in west-central $1 / 9^{\text {th }}$ of map area (latitude $36.2991^{\circ} \mathrm{N}$, longitude $77.4768^{\circ} \mathrm{W}$ ). Surface elevation 58 feet.

\section{LITHOLOGY}

DEPTH IN FEET

\section{Older Alluvium}

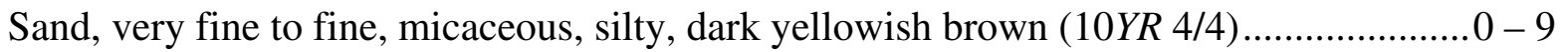

Sand, very fine to fine, silty, clayey, sticky, dark yellowish brown $(10 Y R$ 4/4) grading down at 16 feet to yellowish gray $(5 Y 7 / 2)$ mottled moderate yellowish brown $(10 Y R$ 5/6) $9-22$

Gravel, round to subround quartz clasts up to $6 \mathrm{~cm}$ in diameter, in medium to very coarse sand matrix, silty, dark grayish orange (10YR 6/4) grading through dark yellowish orange (10YR 6/8) (25-31 feet) to pale olive $(10 Y 6 / 2)$ $22-34$

\section{Clubhouse Formation}

Sand, very fine to fine, silty, clayey, very micaceous, light olive brown (5Y 5/4) (34-36 feet) grading to greenish gray (5GY 6/1) mottled moderate olive brown $(5 Y 4 / 4)$ $34-41$

Base of older alluvium: +24 feet elevation

Bottomed in Clubhouse Formation 


\section{CONWAY QUADRANGLE}

CW-03-1: 3.23 miles west of the east quadrangle border, 5.15 miles north of the south quadrangle border, in central $1 / 9^{\text {th }}$ of map area (latitude $36.4498^{\circ} \mathrm{N}$, longitude $77.1824^{\circ} \mathrm{W}$ ). Surface elevation 39 feet.

\section{LITHOLOGY}

DEPTH IN FEET

Fill, clayey and silty sand $0-2$

\section{Alluvium}

Sand, fine, well sorted, silty, unconsolidated, dark yellowish brown $(10 Y R 4 / 2)$ grading through dark yellowish orange (10YR 6/6) (2.5-3 feet) through grayish orange (10YR 6.5/4) (3-6 feet) to pale orange (10YR 7/2) $2-7$

Sand, medium to coarse grading down to coarse to very coarse, contains scattered round quartz pebbles up to $1 \mathrm{~cm}$ in diameter, grayish orange (10YR 6.5/4) $7-11$

\section{Yorktown Formation (Zone 2)}

Sand, very fine, silty, clayey, dark yellowish orange (10YR 6/6) $11-12$

Sand, very fine, silty, clayey, shelly (mostly Mulinia sp.) to very shelly near base, medium greenish gray $(5 G 5 / 1)$ $12-19$

\section{Eastover Formation}

Sand, fine, well sorted, slightly silty, sparsely shelly, grayish olive (10Y 4/2) $.19-21$

Sand, fine, well sorted, slightly silty, interbedded with silt, very fine sandy, dark greenish gray $(5 G 4 / 1)$ $.21-28$

Sand, fine, silty, sparse shell fragments locally present, round light and dark gray quartz pebbles up to $1 \mathrm{~cm}$ in diameter at base, dark greenish gray $(5 G 4 / 1)$ grading downward to dark grayish olive (10Y 3/2) around 40 feet $.28-51$

\section{Cape Fear Formation}

Sand, very fine to fine grading down to fine to medium, silty, slightly clayey, micaceous, dense, medium greenish gray $(5 G Y 7 / 1)$ $51-56$

Base of alluvium:

Base of Yorktown Formation (Zone 2):

Base of Eastover Formation:
+28 feet elevation

+20 feet elevation

-12 feet elevation

Bottomed in Cape Fear Formation 
CW-03-2: 2.65 miles west of the east quadrangle border, 3.20 miles north of the south quadrangle border, in central $1 / 9^{\text {th }}$ of map area (latitude $36.4215^{\circ} \mathrm{N}$, longitude $77.1718^{\circ} \mathrm{W}$ ). Surface elevation 98 feet.

\section{LITHOLOGY}

DEPTH IN FEET

\section{Windsor Formation}

Sand, very fine to medium, dominantly fine, silty, clayey, dusky

yellow $(5 Y 6 / 4)$ $0-1$

Sand, very fine to medium grading down to medium to very coarse, poorly sorted, angular to subangular, silty, clayey, contains scattered round quartz granules and pebbles up to $1 \mathrm{~cm}$ in diameter, light yellowish gray $(5 Y 8 / 2)$ grading down to pale olive gray $(5 Y 4 / 1)$ mottled dark yellowish orange $(10 Y R$ 6/6) $1-6$

Sand, medium to very coarse, silty, pebbly, dark yellowish orange $(10 Y R 6 / 6)$ $6-14$

\section{Upper Bacons Castle Formation, Bahramsville Member}

Sand, very fine, silty and clayey, micaceous, dark yellowish orange $(10 Y R$ 6/6) grading down to dark gray $(N 4)$ in basal foot $14-19$

Sand, very fine, silty, contains scattered subangular quartz granules and small pebbles up to $0.5 \mathrm{~cm}$ in diameter, pale olive gray $(5 Y 6 / 2)$ $19-23$

Sand, medium to very coarse, with scattered round quartz pebbles up to $1 \mathrm{~cm}$ in diameter, silty, pale olive gray $(5 Y 7 / 1)$ grading through yellowish orange $(10 Y R 7 / 6 ; 27-28$ feet $)$ through yellowish gray $(5 Y 8 / 1 ; 28-31$ feet) through light grayish orange $(10 Y R$ 8/4; 31-34 feet) to dark grayish orange (10YR 6/4; 34-38 feet) $23-38$

Silt, clayey, light olive gray $(5 Y 5 / 2)$, thin layer one inch thick at 38

Sand, medium to very coarse, silty, clayey, micaceous, light olive gray $(5 Y 5 / 2)$ grading by base to medium greenish gray $(5 G Y 5 / 1)$ $.38-41$

\section{Chowan River Formation}

Sand, fine to medium, silty, thixotropic, medium olive gray $(5 Y 5 / 1)$ $.41-56$

Base of Windsor Formation:

+84 feet elevation

Base of Upper Bacons Castle Formation (Bahramsville Member): $\quad+57$ feet elevation

Bottomed in Chowan River Formation 


\section{DARLINGTON QUADRANGLE}

DA-02-1: 3.12 miles west of the east quadrangle border, 7.22 miles north of the south quadrangle border, in north-central $1 / 9^{\text {th }}$ of map area (latitude $36.3543^{\circ} \mathrm{N}$, longitude $77.6803^{\circ} \mathrm{W}$ ). Surface elevation 143 feet.

\section{LITHOLOGY}

DEPTH IN FEET

Road fill $0-2$

\section{Lower Bacons Castle Formation, Varina Grove Member}

Sand, fine to coarse, dominantly medium, subangular to subround, dark yellowish orange (10YR 6/6) grading down to light brown $(5 Y R 5 / 6)$ $2-6$

Sand, very fine to medium, dominantly fine, very silty, very clayey, micaceous, breaks along platy fractures, medium greenish gray (5GY 7/1) streaked dark yellowish orange (10YR 6/6) $6-11$

Sand, dominantly fine, very silty, very clayey, grayish yellow $(10 Y R 7 / 4)$ grading down to medium yellowish gray $(5 Y 7 / 1)$ $11-15$

Sand, fine, well sorted, slightly silty, soft, contains $1-2 \%$ very fine to fine dark heavy minerals, medium orange (10YR 5/6) $15-16$

Sand, fine to medium grading down to medium, silty, soft, contains abundant very fine to fine dark heavy minerals throughout and round quartz pebbles up to $0.5 \mathrm{~cm}$ in diameter at base, medium yellowish gray $(5 Y 7 / 1)$ grading down to dark grayish yellow (5Y 7/4) $16-21$

\section{Yorktown Formation (Zone 2)}

Silt, very fine sandy, micaceous, moderate reddish brown $(10 R 4 / 6)$ grading down by 21.5 feet to medium gray $(N 5)$ $21-24$

Gravel, subangular to subround quartz pebbles up to $2 \mathrm{~cm}$ in diameter, in silty, very fine to fine quartz sand matrix, medium gray $(N 5)$.... $.24-26$

\section{Eastern Carolina Slate Belt Rocks}

Saprolite, angular quartz grains and clay pods in clay matrix, micaceous, greenish gray $(5 G 6 / 1)$ grading down to dark grayish yellow $(5 Y 7 / 4)$ $26-31$
Base of Lower Bacons Castle Formation (Varina Grove Member):
+122 feet elevation
Base of Yorktown Formation (Zone 2):
+117 feet elevation

Bottomed in Eastern Carolina Slate Belt rocks 
DA-02-2: 5.77 miles west of the east quadrangle border, 4.11 miles north of the south quadrangle border, in northwest $1 / 9^{\text {th }}$ of map area (latitude $36.3719^{\circ} \mathrm{N}$, longitude $77.7333^{\circ} \mathrm{W}$ ). Surface elevation 193 feet.

\section{LITHOLOGY}

DEPTH IN FEET

\section{Chowan River Formation}

Sand, fine to medium, well sorted, loose, very fine to fine dark heavy mineral grains appear at one foot and become more abundant downward, dusky yellow $(5 Y 6 / 4)$ $0-6$

Sand, dominantly fine to medium, scattered subround to round coarse grains present, very fine to fine dark heavy mineral grains abundant, silty, thixotropic, yellowish gray (5Y 7/2) grading to light orange pink $(10 R 8 / 4)$ $6-24$

Sand, dominantly fine to medium, scattered subround to round coarse grains present, silty, round quartz pebbles up to $3 \mathrm{~cm}$ in diameter present at base, dusky yellow (5Y 6/4). $.24-33$

\section{Eastern Carolina Slate Belt rocks}

Silt, slightly micaceous, much denser than above, pale grayish yellow (5Y 9/4) grading down by 41 feet to moderate greenish gray $(5 G 7 / 1)$

Base of Chowan River Formation: +160 feet elevation

Bottomed in Eastern Carolina Slate Belt rocks 
DA-03-3: 3.62 miles west of the east quadrangle border, 3.31 miles north of the south quadrangle border, in central $1 / 9^{\text {th }}$ of map area (latitude $36.2981^{\circ} \mathrm{N}$, longitude $77.6896^{\circ} \mathrm{W}$ ). Surface elevation 135 feet.

\section{LITHOLOGY}

DEPTH IN FEET

\section{Lower Bacons Castle Formation, Varina Grove Member}

Sand, fine to coarse, coarse grains round, poorly sorted, silty, clayey, yellowish brown $(10 Y R$ 5/2) grading through light olive brown (5Y 5/4; 0.5-1.0 foot) to yellowish gray (5Y 7/2) mottled moderate reddish brown $(10 R 4 / 6)$ $0-7$

Sand, medium to coarse, contains scattered round quartz pebbles up to $1 \mathrm{~cm}$ in diameter, light brown $(5 Y R 6 / 4)$ mottled grayish orange (10YR 7/4) $.7-11$

Sand, medium to very coarse, contains scattered subround to round quartz pebbles up to $1 \mathrm{~cm}$ in diameter, silty, pale grayish orange (10YR 9/4) $11-20$

\section{Yorktown Formation (Zone 2)}

Silt, very fine sandy, clayey, mollusk shells abundant, round quartz pebbles up to $2 \mathrm{~cm}$ in diameter abundant in basal foot, dark yellowish orange (10YR 6/6) grading through dusky yellow (5Y 6/4; 20-23 feet) to medium greenish gray $(5 G 5 / 1)$ $20-27$

\section{Eastern Carolina Slate Belt rocks}

Saprolite, angular quartz grains floating in a silt and clay matrix, some foliation fabric discernable, grayish green $(10 G 4 / 2)$ grading down to dark olive brown (5Y 3/4) mottled olive gray $(5 Y 4 / 1)$.... $.27-31$

Refusal, hit impenetrable rock at 31
Base of Lower Bacons Castle Formation (Varina Grove Member):
+115 feet elevation
Base of Yorktown Formation (Zone 2):
+108 feet elevation

Bottomed in Eastern Carolina Slate Belt rocks 
DA-03-4: 5.74 miles west of the east quadrangle border, 4.10 miles north of the south quadrangle border, in west-central $1 / 9^{\text {th }}$ of map area (latitude $36.3095^{\circ} \mathrm{N}$, longitude $77.7274^{\circ} \mathrm{W}$ ). Surface elevation 205 feet.

\section{LITHOLOGY}

DEPTH IN FEET

\section{Chowan River Formation}

Sand, fine to medium grading down to medium to coarse, silty, round quartz granules and pebbles up to $0.5 \mathrm{~cm}$ present at base and one quartz discoid, grayish orange (10YR 7/4) grading down to dark yellowish orange $(10 Y R 6 / 6)$ $0-3$

Silt, very fine sandy, clayey, stiff, sharp contact with bed above, yellowish gray $(5 Y 7 / 2)$ mottled moderate reddish brown $(10 R 4 / 8)$. $3-6$

Sand, fine to medium, well sorted, micaceous, moderate reddish brown $(10 R 4 / 6)$ mottled light yellowish gray $(5 Y 8 / 2)$ grading through dark yellowish orange $(10 Y R$ 6/6) to yellowish orange $(10 Y R 7 / 6)$ $6-11$

Sand, very fine to medium, poorly sorted, subangular, contains scattered round quartz pebbles up to $1 \mathrm{~cm}$ in diameter and concentrated quartz pebbles at base, dark yellowish orange $(10 Y R$ 6/6) $11-19$

\section{Eastern Carolina Slate Belt Rocks}

Saprolite, subangular medium quartz grains floating in a silt and clay matrix, light brown $(5 Y R 5 / 6)$ $19-28$

Saprolite, silt and clay, banded foliation texture discernible, reddish brown $(10 R 5 / 6)$ $.28-31$

Base of Chowan River Formation: +186 feet elevation

Bottomed in Eastern Carolina Slate Belt saprolite 


\section{DAWSON CROSSROADS QUADRANGLE}

DC-03-1: 0.77 mile west of the east quadrangle border, 5.48 miles north of the south quadrangle border, in east-central $1 / 9^{\text {th }}$ of map area (latitude $36.2044^{\circ} \mathrm{N}$, longitude $77.5134^{\circ} \mathrm{W}$ ). Surface elevation 126 feet.

\section{LITHOLOGY}

DEPTH IN FEET

\section{Upper Bacons Castle Formation, Bahramsville Member}

Sand, very fine to fine, silty, clayey, dark yellowish brown (10YR 4/2)

grading through dusky yellowish brown $(10 Y R 2 / 2)$ to pale yellowish

brown $(10 Y R 6 / 2)$

$0-1$

Sand, very fine to fine, silty, clayey, medium brownish gray $(5 Y R 5 / 1)$

grading through moderate yellowish gray (5Y 7/1) (3-6 feet) to light

olive gray $(5 Y$ 6/1) mottled dark yellowish orange (10YR 6/6) and

moderate reddish brown $(10 R 4 / 6)$ $1-9$

Sand, medium to coarse, silty, dark yellowish gray $(5 Y 6 / 2)$ grading to medium brownish gray $(5 Y R 5 / 1)$, goes abruptly to pale yellowish gray (5Y 8/2; 14-15 feet) and then grades through yellowish orange $(10 Y R$ 7/8; $15-16$ feet) and through dark grayish orange (10YR 6/4;

$16-28$ feet) to yellowish orange (10YR 7/8) $9-29$

Silt, very fine sandy, clayey, interbedded with sand, very fine, silty, clayey, dark yellowish gray $(5 Y 6 / 2)$ grading down to greenish gray $(5 G Y 6 / 1)$ $29-34$

Sand, fine to medium, silty, thixotropic, light greenish gray $(5 G Y 7 / 1)$, grades to $34-43$

Sand, medium to coarse, contains abundant round quartz pebbles up to $1 \mathrm{~cm}$ in diameter, light greenish gray $(5 G Y 7 / 1)$ $43-46$

Sand, medium to coarse, sparse pebbles present below 56 feet, light greenish gray $(5 G Y 7 / 1)$ $.46-60$

Gravel, subround to round quartz pebbles up to $3 \mathrm{~cm}$ in diameter, in medium to coarse sand matrix $60-61$

\section{Yorktown Formation (Zone 2)}

Sand, fine, silty, mollusk shells abundant, medium greenish gray $(5 G 5 / 1)$ $61-66$

Base of Upper Bacons Castle Formation (Bahramsville Member): +65 feet elevation Bottomed in Yorktown Formation (Zone 2) 
DC-03-2: 4.73 miles west of the east quadrangle border, 5.02 miles north of the south quadrangle border, in west-central $1 / 9^{\text {th }}$ of map area (latitude $36.1980^{\circ} \mathrm{N}$, longitude $77.5844^{\circ} \mathrm{W}$ ). Surface elevation 112 feet.

\section{LITHOLOGY}

DEPTH IN FEET

\section{Upper Bacons Castle Formation, Bahramsville Member}

Sand, fine, grayish orange (10YR 7/4), grading down to sand, very fine to fine, silty, clayey, stiff, dark yellowish orange $(10 Y R 6 / 6)$ $0-1$

Sand, very fine to fine, silty, clayey, light brown $(5 Y R$ 5/6) grading down to silt, clayey, very fine sandy, reddish brown $(10 R 5 / 6)$ mottled yellowish gray $(5 Y 7 / 2)$ $1-6$

Silt, clayey, very fine to fine sandy, micaceous, stiff, moderate reddish brown $(10 R 4 / 6)$ mottled yellowish gray $(5 Y 7 / 2)$ grading down to moderate reddish brown $(10 R 4 / 6)$ $6-11$

Sand, fine to medium grading down to medium to coarse, silty, clayey in some areas, medium yellowish orange (10YR 7/6) grading down to pale brown $(5 Y R 6 / 6)$ $11-22$

\section{Yorktown Formation (Zone 2)}

Silt, very fine sandy, clayey, dark orange (10YR 6/8) grading down through yellowish gray $(5 Y 7 / 2)$ mottled dark orange (10YR 6/8; 23-24 feet) through moderate brown (5YR 4/6; 24-24.5 feet) through dark orange (10YR 6/8; 24.5-25 feet) through dark grayish yellow $(5 Y 7 / 4 ; 25-25.5)$ to medium greenish gray $(5 G 5 / 1)$. $22-26$

Base of Upper Bacons Castle Formation (Bahramsville Member): +90 feet elevation

Bottomed in Yorktown Formation (Zone 2) 
DC-03-3: 4.74 miles west of the east quadrangle border, 5.43 miles north of the south quadrangle border, in west-central $1 / 9^{\text {th }}$ of map area (latitude $36.2039^{\circ} \mathrm{N}$, longitude $77.5846^{\circ} \mathrm{W}$ ). Surface elevation 84 feet.

\section{LITHOLOGY}

DEPTH IN FEET

\section{Alluvium}

Sand, very fine to fine, silty, clayey, yellowish brown (10YR 5/2) $.0-2$

Sand, very fine to fine, silty, clayey, dark yellowish gray $(5 Y 6 / 2)$ grading down to dark yellowish gray $(5 Y 6 / 2)$ mottled reddish brown $(10 R 5 / 6)$ $2-6$

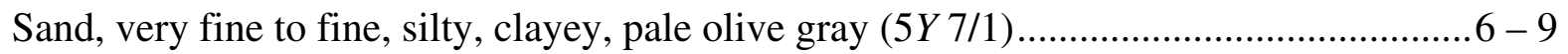

Sand, fine to medium, silty, yellowish gray $(5 Y 7 / 2)$ becoming mottled with dark yellowish orange (10YR 6/6) in basal 0.5 foot $9-12$

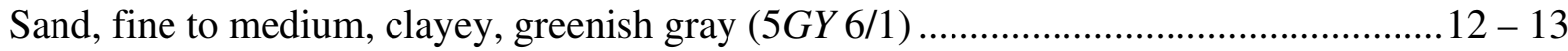

Sand, fine to coarse, silty, olive gray $(5 Y 4 / 2)$ grading down through light olive gray $(5 Y 6 / 1 ; 15-16$ feet $)$ to medium greenish gray $(5 G 5 / 1)$ $13-22$

\section{Yorktown Formation (Zone 2)}

Sand, very fine to fine, silty, clayey, medium greenish gray $(5 G 5 / 1)$, grades to............22 - 32

Sand, fine, silty, sparsely shelly, medium greenish gray $(5 G 5 / 1)$ $32-36$

Sand, very fine to fine grading down to fine to medium, silty, clayey, shelly, rounded shell fragments abundant along basal contact, medium greenish gray $(5 G 5 / 1)$ $.36-41$

\section{Clubhouse Formation}

Sand, very fine to fine, silty, clayey, very dense, medium greenish gray $(5 G 7 / 1)$ mottled moderate olive brown $(5 Y 4 / 4)$ and moderate reddish brown $(10 R 4 / 6)$ $41-46$
Base of alluvium:
+62 feet elevation
Base of Yorktown Formation (Zone 2):
+43 feet elevation

Bottomed in Clubhouse Formation 


\section{DRAKE QUADRANGLE}

DK-03-1: 4.68 miles west of the east quadrangle border, 0.10 mile north of the south quadrangle border, on border of south-central and southwest $1 / 9^{\text {ths }}$ of map area (latitude $36.0018^{\circ} \mathrm{N}$, longitude $\left.77.8329^{\circ} \mathrm{W}\right)$. Surface elevation 142 feet.

\section{LITHOLOGY}

DEPTH IN FEET

\section{Upper Bacons Castle Formation, Bahramsville Member}

Sand, medium to very coarse, subangular to subround, very silty, very clayey, pale grayish orange (10YR 8/4) streaked yellowish brown $(10 Y R$ 5/2) grading down through dark yellowish orange (10YR 6/6; 0.5-2.0 feet) to yellowish gray (5Y 7/2) mottled reddish brown $(10 R 5 / 6)$, sharp basal contact. $0-4$

Sand, medium to very coarse, subangular to subround, slightly silty, slightly clayey, light brownish gray (5YR 6/1) grading down to grayish orange (10YR 7/4), sharp basal contact .... $4-8$

Silt, clayey, finely micaceous, dense, sticky, dark yellowish orange $(10 Y R$ 6/6) grading down to reddish brown $(10 R 5 / 6)$ mottled yellowish gray $(5 Y 7 / 2)$, grades rapidly to $8-10$

Sand, fine to coarse, dominantly medium, silty, clayey, dense, yellowish gray $(5 Y 7 / 2)$, white streaks suggest kaolinitized former coarse to very coarse feldspar sand grains $10-11$

Silt, clayey, finely micaceous, dense, sticky, yellowish gray $(5 Y 7 / 2)$ $11-14$

Sand, medium to coarse, contains scattered subround to round quartz pebbles up to $1 \mathrm{~cm}$ in diameter, dark grayish orange (10YR 6/4) grading down to dark yellowish orange $(10 Y R$ 6/6) $.14-15$

\section{Yorktown Formation (Zone 2)}

Silt, clayey, finely micaceous, dense, sticky, yellowish gray $(5 Y 7 / 2)$ streaked dark yellowish orange (10YR 6/6) grading down to medium greenish gray $(5 G 5 / 1)$ mottled medium olive brown $(5 Y 4 / 4)$ and dark grayish olive $(10 Y 3 / 2)$, grades rapidly to $15-19$

Sand, fine, very well sorted, slightly silty, medium greenish gray $(5 G Y 5 / 1)$ $19-26$

Sand, fine, very well sorted, slightly silty, micaceous, shell fragments abundant with average size coarsening downward, some whole Mulinia sp. present, medium greenish gray $(5 G 5 / 1)$ $.26-36$ 
Sand, fine to medium grading down to medium to coarse, subangular, shelly (including Mulinia sp., Rangia sp., Venericardia sp., barnacles, etc.), round black-stained quartz pebbles up to $3 \mathrm{~cm}$ in diameter abundant, medium greenish gray $(5 G 5 / 1)$, sharp basal contact

$36-39$

\section{Clubhouse Formation}

Sand, fine to medium, moderately well sorted, very silty, very clayey, dense, stiff, sticky, very hard to get off stems, moderate grayish green $(10 G 5 / 2)$ grading rapidly to grayish green $(10 G 4 / 2)$, mottles of moderate brown $(5 Y R 4 / 6)$ and moderate olive gray $(5 Y 4 / 2)$ present below 42 feet and white streaks of kaolin scattered throughout.....................................39-46

Base of Upper Bacons Castle Formation (Bahramsville Member): $\quad+127$ feet elevation Base of Yorktown Formation (Zone 2): $\quad+103$ feet elevation

Bottomed in Clubhouse Formation 
DK-03-2: 5.38 miles west of the east quadrangle border, 0.53 mile north of the south quadrangle border, southwest $1 / 9^{\text {th }}$ of map area (latitude $36.0080^{\circ} \mathrm{N}$, longitude $77.8450^{\circ} \mathrm{W}$ ). Surface elevation 165 feet.

\section{LITHOLOGY}

DEPTH IN FEET

\section{Lower Bacons Castle Formation, Varina Grove Member}

Sand, fine to medium, subround to round, very clean, dark grayish

yellow $(5 Y 5 / 4)$

$.0-1$

Sand, medium to coarse, subround to round, contains $2-5 \%$ very fine

to fine dark heavy mineral grains, slightly silty, dark grayish yellow

(5Y 5/4) grading to dark yellowish orange (10YR 6/6) mottled

yellowish gray $(5 Y 7 / 2)$ $1-5$

Sand, fine to medium, subround to round, contains $2-5 \%$ very fine to fine dark heavy mineral grains, slightly silty, dark yellowish orange $(10 Y R$ 6/6) mottled yellowish gray (5Y7/2) and reddish brown $(10 R 5 / 8)$ $5-6$

Sand, fine to medium, subround to round, contains 2-5\% very fine to fine dark heavy mineral grains, slightly silty, yellowish gray $(5 Y 7 / 2)$ sparsely mottled pale yellowish brown (10YR 6/2) $6-10$

Sand, fine to medium grading down to dominantly fine, contains $2-5 \%$ very fine to fine dark heavy mineral grains, very silty, very clayey, dense, dark yellowish orange (10YR 6/6) mottled yellowish gray $(5 Y 7 / 2)$. $10-21$

Sand, fine to medium, contains quartz granules and pebbles up to $2 \mathrm{~cm}$ including discoids, $2-5 \%$ very fine to fine dark heavy mineral grains present, silty, dark yellowish orange (10YR 6/6).... $21-23$

Sand, fine to medium, $2-5 \%$ very fine to fine dark heavy mineral grains present, silty, dark yellowish orange (10YR 6/6) $.23-29$

Sand, medium to very coarse, contains quartz pebbles up to $6 \mathrm{~cm}$ in diameter, dark yellowish orange (10YR 6/6) $.29-31$

\section{Eastern Carolina Slate Belt Rocks}

Saprolite, coarse angular equant quartz grains floating in a silt and clay matrix, micaceous, dark grayish yellow (5Y 5/4) $31-42$

Base of Lower Bacons Castle Formation (Varina Grove Member): $\quad+134$ feet elevation

Bottomed in Eastern Carolina Slate Belt metamorphosed granite 
DK-03-3: 4.78 miles west of the east quadrangle border, 8.07 miles north of the south quadrangle border, northwest $1 / 9^{\text {th }}$ of map area (latitude $36.1169^{\circ} \mathrm{N}$, longitude $77.8349^{\circ} \mathrm{W}$ ). Surface elevation 155 feet.

\section{LITHOLOGY}

DEPTH IN FEET

\section{Lower Bacons Castle Formation, Varina Grove Member}

Sand, fine to coarse, dominantly fine, round, clean, dark yellowish brown $(10 Y R 4 / 2)$ grading down to grayish orange (10YR 6/4) $0-1$

Sand, fine, contains 1-2\% very fine to fine dark heavy mineral grains, slightly silty and clayey at top but becoming more silty and clayey downward, dark grayish orange (10YR 7/4) mottled dark yellowish orange (10YR 6/6) and yellowish gray (5Y 7/2), mottles of reddish brown $(10 R 4 / 6)$ appear below 4 feet, grades to $1-11$

Silt, very fine sandy, contains scattered quartz granules and small pebbles up to $1 \mathrm{~cm}$ in diameter, rounded between 14 and 16 feet, dark grayish orange (10YR 7/4) mottled dark yellowish orange (10YR 6/6), yellowish gray (5Y 7/2), and reddish brown $(10 R 4 / 6)$, grades rapidly to. $11-17$

Sand, fine grading downward through medium to coarse, below 20 feet contains scattered rounded quartz pebbles up to $4 \mathrm{~cm}$ in diameter, dark grayish orange (10YR 7/4) mottled dark yellowish orange (10YR 6/6), yellowish gray (5Y 7/2), and reddish brown $(10 R 4 / 6)$ $17-24$

\section{Eastern Carolina Slate Belt Rocks}

Saprolite, angular very coarse equant quartz grains in clay and silt matrix, dark grayish orange (10YR 6/4) grading down to dark yellowish brown (10YR 4/4) $.24-25$

Refusal, hit solid rock at 25

Base of Lower Bacons Castle Formation (Varina Grove Member): +131 feet elevation

Bottomed in Eastern Carolina Slate Belt metamorphosed granite 
DK-03-4: 0.79 mile west of the east quadrangle border, 0.08 mile north of the south quadrangle border, southeast $1 / 9^{\text {th }}$ of map area (latitude $36.0013^{\circ} \mathrm{N}$, longitude $77.7638^{\circ} \mathrm{W}$ ). Surface elevation 120 feet.

\section{LITHOLOGY}

DEPTH IN FEET

Road fill $.0-4$

\section{Lower Bacons Castle Formation, Varina Grove Member}

Sand, fine with rare medium to coarse grains, clean, olive (10Y 5/2)

mottled moderate olive gray $(5 Y 5 / 2)$ $4-6$

Sand, very fine to medium, silty, clayey, dark yellowish orange (10YR 6/6) mottled yellowish gray (5Y 7/2) $6-11$

Sand, very fine to medium, silty, slightly clayey, dark yellowish orange $(10 Y R 6 / 6)$ mottled yellowish gray $(5 Y 7 / 2)$ and reddish brown (10R 5/6) $11-14$

Sand, very fine to medium, silty, very clayey, dark yellowish orange (10YR 6/6) mottled yellowish gray (5Y 7/2) and reddish brown (10R 5/6) $.14-16$

Silt, clayey, sandy, yellowish gray $(5 Y 7 / 2)$ mottled dark yellowish orange (10YR 6/6) and reddish brown (10R 5/6) $16-28$

\section{Yorktown Formation (Zone 2)}

Silt, clayey, very fine sandy, very fine mica abundant, dark yellowish gray $(5 Y 6 / 2)$ grading by 32 feet to medium greenish gray $(5 G 5 / 1)$ $.28-38$

Sand, very fine to fine, slightly silty, medium greenish gray $(5 G 5 / 1) \ldots \ldots \ldots \ldots \ldots \ldots \ldots \ldots \ldots \ldots . . . . .38-45$

Sand, very fine to fine, slightly silty, shelly, greenish gray $(5 G Y$ 6/1) .............................45- 70

Sand, very fine, slightly silty, clayey, sparsely shelly, moderate olive gray $(5 Y 4 / 2)$ $70-75$

Sand, fine to medium, contains abundant round quartz pebbles up to $3 \mathrm{~cm}$ in diameter, moderate olive gray $(5 Y 4 / 2)$ $.75-76$

\section{Clubhouse Formation}

Sand, medium to very coarse, subround to round grading down to subangular to subround, clayey, dense, medium greenish gray (5GY 7/1) mottled moderate olive brown (5Y 4/4), dusky yellow $(5 Y 6 / 4)$, and pale brownish gray (5YR 7/1) $.76-81$ 
Base of Lower Bacons Castle Formation (Varina Grove Member): $\quad$ +92 feet elevation Base of Yorktown Formation (Zone 2): +44 feet elevation

Bottomed in Clubhouse Formation 
DK-03-5: 0.74 mile west of the east quadrangle border, 8.04 miles north of the south quadrangle border, northeast $1 / 9^{\text {th }}$ of map area (latitude $36.1166^{\circ} \mathrm{N}$, longitude $77.7632^{\circ} \mathrm{W}$ ). Surface elevation 135 feet.

\section{LITHOLOGY}

DEPTH IN FEET

\section{Upper Bacons Castle Formation, Bahramsville Member}

Sand, very fine to fine, silty, light olive gray (5Y 5.5/1). $.0-1$

Sand, very fine, very silty, clayey, yellowish gray $(5 Y 7 / 2)$ blotched dark yellowish orange $(10 Y R$ 6/6).... $1-7$

Sand, fine grading down through fine to medium to fine to coarse, pale olive gray $(5 Y 7 / 1)$ mottled dark yellowish orange (10YR 6/6). $.7-10$

Silt, very fine sandy, clayey, stiff, dense, pale olive gray $(5 Y 7 / 1)$ mottled dark yellowish orange $(10 Y R 6 / 6)$ $10-17$

Sand, very fine to fine with scattered medium and coarse grains, poorly sorted, very silty, thixotropic, pale grayish orange (10YR 8/4), coarsens down to. $17-29$

Sand, medium to very coarse, granular, slightly silty, pale grayish orange $(10 Y R$ 8/4) $29-35$

Sand, medium to very coarse, gravelly with round quartz clasts up to $4 \mathrm{~cm}$ in diameter, dark grayish orange $(10 Y R 7 / 6)$ $35-36$

\section{Yorktown Formation (Zone 2)}

Silt, very fine sandy, slightly clayey, finely micaceous, mollusk shells present between 38 and 41 feet, dark greenish gray $(5 G Y 4 / 1)$ $.36-48$

\section{Eastern Carolina Slate Belt Rocks}

Saprolite, scattered angular medium quartz grains floating in a clayey

silt matrix, slightly micaceous, moderate yellowish brown (10YR 5.5/4) $48-76$
Base of Upper Bacons Castle Formation (Bahramsville Member): Base of Yorktown Formation (Zone 2):
+99 feet elevation +87 feet elevation

Bottomed in Eastern Carolina Slate Belt Rocks 
DK-03-6: 3.30 miles west of the east quadrangle border, 4.91 miles north of the south quadrangle border, central $1 / 9^{\text {th }}$ of map area (latitude $36.0714^{\circ} \mathrm{N}$, longitude $77.8067^{\circ} \mathrm{W}$ ). Surface elevation 125 feet.

\section{LITHOLOGY}

DEPTH IN FEET

\section{Upper Bacons Castle Formation, Bahramsville Member}

Sand, fine with scattered grains of medium and coarse, coarse fraction round, grayish orange (10YR 6/4) grading down to dark yellowish orange $(10 Y R 6 / 6)$ $0-1$

Sand, fine to medium, silty, slightly clayey, dark yellowish orange (10YR 6/6) with mottles of moderate reddish orange (10R 6/8) grading down to yellowish gray $(5 Y 7 / 2)$ mottled dark yellowish orange $(10 Y R 6 / 6)$ $1-6$

Sand, dominantly fine with some medium, very silty, clayey, dark yellowish orange $(10 Y R$ 6/6) $6-9$

Silt, clayey, very fine to fine sandy, stiff and sticky, yellowish gray $(5 Y 7 / 2)$ $9-16$

Sand, very fine to fine, silty, yellowish gray $(5 Y 7 / 2)$, grades to $16-19$

Sand, medium to coarse, contains abundant quartz pebbles up to $4 \mathrm{~cm}$ in diameter, dark grayish orange (10YR 6/4) $19-22$

\section{Yorktown Formation (Zone 2)}

Silt, very fine sandy, yellowish orange (10YR 7/8) grading by 23.5 feet to medium greenish gray $(5 G 5 / 1)$, mollusk shells abundant below 28 feet (including pectenids) $22-38$

Sand, very coarse, one inch-thick layer at 38

\section{Metamorphosed Granite?}

Refusal, impenetrable rock ledge, nearby mapping suggests granite is the likely lithology at 38

$\begin{array}{lr}\text { Base of Upper Bacons Castle Formation (Bahramsville Member): } & +103 \text { feet elevation } \\ \text { Base of Yorktown Formation (Zone 2): } & +87 \text { feet elevation }\end{array}$ Bottomed on metamorphosed granite? 
DK-03-7: 0.43 mile west of the east quadrangle border, 4.41 miles north of the south quadrangle border, east-central $1 / 9^{\text {th }}$ of map area (latitude $36.0628^{\circ} \mathrm{N}$, longitude $77.7574^{\circ} \mathrm{W}$ ). Surface elevation 98 feet.

\section{LITHOLOGY}

DEPTH IN FEET

\section{Alluvium}

Sand, fine to medium, contains scattered round coarse grains, loose, yellowish brown $(10 Y R 5 / 2)$ and yellowish gray $(5 Y 7 / 2)$ grading down to yellowish brown $(10 Y R$ 5/2) $0-2$

\section{Upper Bacons Castle Formation, Bahramsville Member}

Sand, fine to medium, clayey, silty, dark yellowish orange (10YR 6/6) $2-3$

Sand, fine to medium, contains scattered subround to round coarse

to very coarse grains, micaceous, yellowish orange $(10 Y R 7 / 6)$ $3-6$

Sand, medium to very coarse, contains granules and small pebbles of quartz, dark grayish orange (10YR 6/4) $6-7$

\section{Yorktown Formation (Zone 2)}

Silt, clayey, very fine sandy, yellowish gray $(5 Y 7 / 2)$ mottled moderate brown $(5 Y R 4 / 6)$ $7-9$

Silt, very fine sandy, clayey, medium greenish gray $(5 G 5 / 1)$ $9-16$

Sand, very fine to fine, silty, clayey, very shelly, greenish gray $(5 G 6 / 1)$ grading down to medium greenish gray $(5 G 5 / 1)$ $16-38$

Sand, fine to medium, contains abundant subround to round quartz pebbles up to $5 \mathrm{~cm}$ in diameter and subround phosphate pebbles up to $1 \mathrm{~cm}$ in diameter, light olive gray $(5 Y 5 / 2)$ $38-39$

\section{Clubhouse Formation}

Silt, clayey, very fine sandy, very dense, medium olive gray (5Y 5/1) mottled pale olive gray (5Y7/1), moderate reddish brown $(10 R 4 / 6)$, and light greenish gray $(5 G 8 / 1)$.. $.39-46$

Base of alluvium:

Base of Upper Bacons Castle Formation (Bahramsville Member):

Base of Yorktown Formation (Zone 2):

Bottomed in Clubhouse Formation
+96 feet elevation

+91 feet elevation

+59 feet elevation 
DK-94-8: 5.73 miles west of the east quadrangle border, 1.07 miles north of the south quadrangle border, southwest $1 / 9^{\text {th }}$ of map area (latitude $36.0154^{\circ} \mathrm{N}$, longitude $77.8518^{\circ} \mathrm{W}$ ). Surface elevation 192 feet.

\section{LITHOLOGY}

DEPTH IN FEET

\section{Chowan River Formation}

Sand, fine to coarse, silty, clayey, dense, contains round quartz pebbles up to $1 \mathrm{~cm}$ in diameter and plinthite nodules, moderate yellowish brown (10YR 5/4) grading down through light brown $(5 Y R 5 / 6 ; 2-4$ feet) to moderate reddish brown $(10 R 4 / 6)$ $0-8$

Gravel, round quartz pebbles up to $2 \mathrm{~cm}$ in diameter in fine to coarse sand matrix, moderate reddish brown $(10 R 4 / 6)$ $.8-10$

Sand, medium to coarse, poorly sorted, silty, moderate reddish brown $(10 R 4 / 6)$ $10-11$

Sand, fine to medium, contains scattered polished coarse quartz grains, very fine dark heavy mineral grains abundant, silty, micaceous, dark yellowish orange $(10 Y R 6 / 6)$ grading down by 20 feet to moderate orange pink ( $5 Y R 8 / 4)$, grades rapidly to $11-31$

Sand, very fine to fine, silty, micaceous, very fine dark heavy mineral grains abundant, quartz discoids up to $1.5 \mathrm{~cm}$ in diameter concentrated at base, dark yellowish orange $(10 Y R 6 / 6)$ $31-37$

\section{Metamorphosed Granite}

Saprolite, fine to coarse angular quartz grains in silt and clay matrix, micaceous, moderate reddish orange $(10 R$ 6/6) $37-61$

Base of Chowan River Formation: +155 feet elevation

Bottomed in metamorphosed granite saprolite 


\section{DRAUGHN QUADRANGLE}

DR-03-1: 6.78 miles west of the east quadrangle border, 0.68 mile north of the south quadrangle border, southwest $1 / 9^{\text {th }}$ of map area (latitude $36.0098^{\circ} \mathrm{N}$, longitude $77.6198^{\circ} \mathrm{W}$ ). Surface elevation 90 feet.

\section{LITHOLOGY}

DEPTH IN FEET

\section{Upper Bacons Castle Formation, Bahramsville Member}

Sand, mostly fine but with scattered subround grains up to very

coarse, slightly silty, dark grayish yellow (5Y 6.5/4)...... $0-1$

Sand, fine grading down to medium to coarse, silty, slightly clayey, dark yellowish orange (10YR 6/6). $1-11$

\section{Yorktown Formation (Zone 2)}

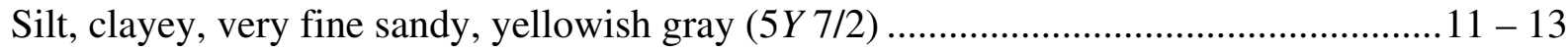

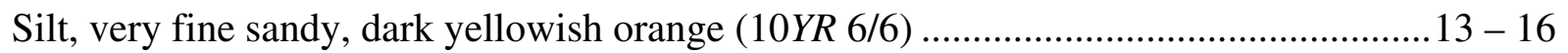

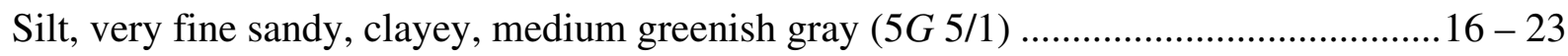

Sand, very fine to fine, silty, clayey, shelly, medium greenish gray $(5 G 5 / 1) \ldots \ldots \ldots \ldots \ldots . . .23-26$

Base of Upper Bacons Castle Formation (Bahramsville Member): +79 feet elevation

Bottomed in Yorktown Formation (Zone 2) 
DR-03-2: 4.15 miles west of the east quadrangle border, 8.17 miles north of the south quadrangle border, north-central $1 / 9^{\text {th }}$ of map area (latitude $36.1184^{\circ} \mathrm{N}$, longitude $77.5737^{\circ} \mathrm{W}$ ). Surface elevation 65 feet.

\section{LITHOLOGY}

DEPTH IN FEET

\section{Alluvium}

Sand, fine to medium, silty, clayey, pale yellowish brown $(10 Y R 6 / 2)$

mottled dark yellowish orange $(10 Y R$ 6/6) $0-1$

Silt, sandy, increasingly clayey downward, dark yellowish orange

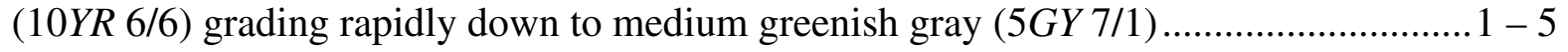

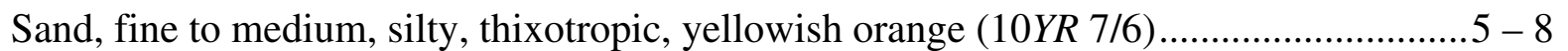

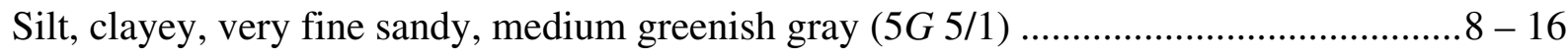

Sand, fine, well sorted, grading down to medium to coarse by base, micaceous, soft, thixotropic, medium brownish gray $(5 Y R 5 / 1)$... $16-22$

\section{Clubhouse Formation}

Sand, medium to coarse, clayey, dense, medium light greenish gray (5GY 8/1) mottled light olive brown (5Y 5/4) and moderate brown $(5 Y R$ 4/6) $.22-31$

Base of alluvium: +43 feet elevation

Bottomed in Clubhouse Formation 
DR-03-3: 0.88 mile west of the east quadrangle border, 7.79 miles north of the south quadrangle border, northeast $1 / 9^{\text {th }}$ of map area (latitude $36.0987^{\circ} \mathrm{N}$, longitude $77.5155^{\circ} \mathrm{W}$ ). Surface elevation 60 feet.

\section{LITHOLOGY}

DEPTH IN FEET

Road fill, pebbly sand

$0-1$

\section{Alluvium}

Sand, fine to medium, silty, clayey, pale yellowish brown (10YR 6/2)

grading down to dark yellowish orange $(10 Y R 6 / 6)$ $1-3$

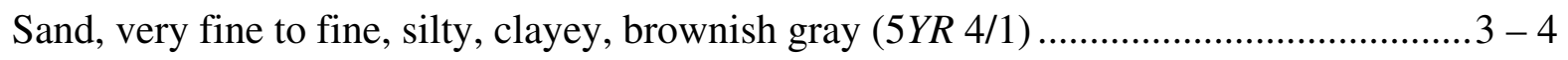

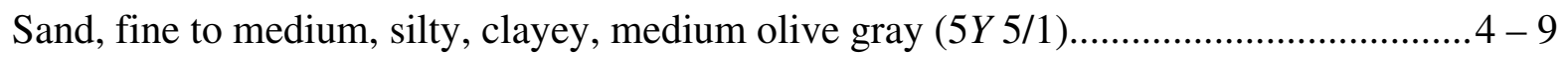

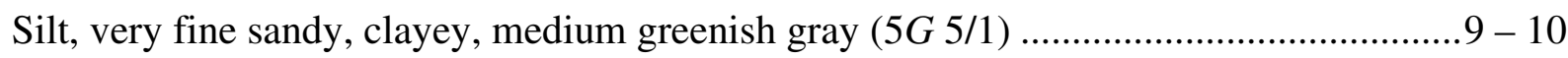

Sand, fine to coarse, granular, silty, thixotropic, contains rounded wood chips, medium olive gray ( $5 Y 5.5 / 1)$ $10-13$

Sand, medium to coarse, subangular, contains scattered very coarse grains, granules, and pebbles up to $0.5 \mathrm{~cm}$ in diameter, dark greenish gray $(5 G Y 4 / 1)$, grades to $13-21$

Sand, medium to very coarse, contains subround to round quartz pebbles up to $3 \mathrm{~cm}$ in diameter, medium greenish gray $(5 G Y 5 / 1)$ $.21-23$

\section{Clubhouse Formation}

Sand, fine, silty, clayey, dense, light brownish gray (5YR 6/1) $23-26$

Sand, fine to medium, coarsening downward to medium to coarse, pale olive gray $(5 Y 7 / 1)$ $26-34$

Sand, fine to medium, silty, clayey, pale olive gray $(5 Y 7 / 1)$ $.34-37$

Silt, clayey, very fine sandy, pale olive gray $(5 Y 7 / 1)$ $.37-38$

Sand, fine to medium, silty, clayey, pale olive gray (5Y 7/1) $.38-41$

Silt, clayey, dense, light olive gray ( $5 Y 6 / 1)$ changing abruptly to moderate reddish brown $(10 R 4 / 6)$ at 42 feet, very tough drilling. $41-44$

Base of alluvium: +37 feet elevation

Bottomed in Clubhouse Formation 
DR-03-4: 0.88 mile west of the east quadrangle border, 0.31 mile north of the south quadrangle border, southeast $1 / 9^{\text {th }}$ of map area (latitude $36.0047^{\circ} \mathrm{N}$, longitude $77.5155^{\circ} \mathrm{W}$ ). Surface elevation 70 feet.

\section{LITHOLOGY}

DEPTH IN FEET

Road fill, medium to coarse sand

$0-1$

\section{Alluvium}

Sand, fine, well sorted, olive gray $(5 Y 4 / 2)$ grading through pale olive brown $(5 Y 6 / 6)$ back to olive gray $(5 Y 4 / 2)$ $1-2$

Silt, clayey, dark yellowish orange (10YR 6/6) mottled light olive gray $(5 Y 5 / 2)$ grading through moderate grayish brown $(5 Y R 3 / 2)(5-6 \mathrm{feet})$ to yellowish gray $(5 Y 6.5 / 2)$ mottled dark yellowish orange $(10 Y R$ 6/6)

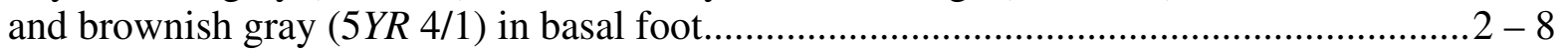

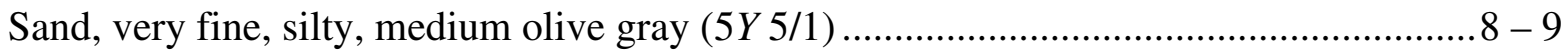

Silt, clayey, very fine sandy, yellowish brown (10YR 5/2) grading down

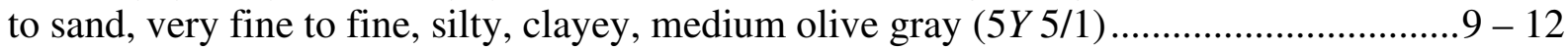

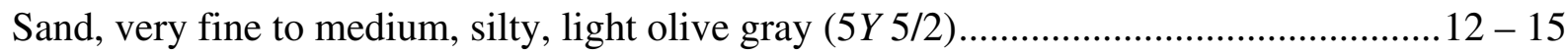

\section{Yorktown Formation (Zone 2)}

Sand, fine, silty, clayey, sparsely shelly at top but more shelly downward, medium greenish gray $(5 G 5 / 1)$ grading down to greenish gray $(5 G 6 / 1)$ $15-26$

Sand, fine grading down to medium, sparsely shelly, greenish gray $(5 G 6 / 1) \ldots \ldots \ldots \ldots \ldots . . .26-32$

Sand, very fine grading down to fine, clayey, medium greenish gray $(5 G Y 5 / 1)$, grades to $32-39$

Sand, medium to coarse, contains abundant subround to round quartz pebbles up to $1 \mathrm{~cm}$ in diameter, medium greenish gray $(5 G Y 5 / 1)$.... $.39-41$

Base of alluvium: $\quad+55$ feet elevation

(Probably bottomed just above Cape Fear Formation) 
DR-03-5: 6.30 miles west of the east quadrangle border, 6.73 miles north of the south quadrangle border, northwest $1 / 9^{\text {th }}$ of map area (latitude $36.0976^{\circ} \mathrm{N}$, longitude $77.6120^{\circ} \mathrm{W}$ ). Surface elevation 125 feet.

\section{LITHOLOGY}

DEPTH IN FEET

\section{Upper Bacons Castle Formation, Bahramsville Member}

Sand, fine, silty, clayey, pale yellowish brown (10YR 6/2) grading down

to grayish orange $(10 Y R 7 / 4)$ $0-1$

Sand, very fine to fine, silty, clayey grading down to slightly clayey, grayish orange (10YR 7/4) grading through dark yellowish orange (10YR 6/6; 2-4 feet) and through yellowish gray (5Y 7/2; 4-6 feet) to dark yellowish orange $(10 Y R 6 / 6)$ mottled yellowish gray $(5 Y 7 / 2)$. $1-9$

Sand, very fine to fine with an accessory fraction of coarse to very coarse, dark yellowish orange (10YR 6/6) mottled yellowish gray $(5 Y 7 / 2)$, about 1 inch thick lens at 9

Sand, very fine to fine, silty, clayey, light yellowish gray $(5 Y 8 / 2)$ mottled moderate reddish brown $(10 R 4 / 6)$, grades to. $9-13$

Silt, clayey, very fine sandy, light yellowish gray (5Y 8/2) mottled moderate reddish brown $(10 R 4 / 6)$, grades to $13-18$

Sand, very fine grading down to fine, clayey, silty, light yellowish gray $(5 Y 8 / 2)$ mottled moderate reddish brown $(10 R 4 / 6)$ $18-22$

Sand, fine to medium grading down to medium to coarse, subangular, silty, slightly clayey, dark grayish orange (10YR 6/4) $.22-31$

\section{Yorktown Formation (Zone 2)}

Silt, clayey, very fine sandy, yellowish gray (5Y 7/2) grading through yellowish orange (10YR 7/6; 32-33 feet) and through yellowish gray $(5 Y 7 / 2 ; 33-35$ feet) to medium yellowish gray $(5 Y 6 / 2)$ streaked pale yellowish brown $(10 Y R 6 / 2)$ and dark grayish yellow $(5 Y 7 / 4)$ $31-37$

Silt, clayey, very fine sandy, medium greenish gray $(5 G 5 / 1)$ $37-46$

Base of Upper Bacons Castle Formation (Bahramsville Member): +94 feet elevation Bottomed in Yorktown Formation (Zone 2) 


\section{ENFIELD QUADRANGLE}

EN-03-1: 3.10 miles west of the east quadrangle border, 3.21 miles north of the south quadrangle border, central $1 / 9^{\text {th }}$ of map area (latitude $36.1716^{\circ} \mathrm{N}$, longitude $77.6798^{\circ} \mathrm{W}$ ). Surface elevation 114 feet.

\section{Upper Bacons Castle Formation, Bahramsville Member}

Sand, very fine, silty, clayey, light olive gray (5Y 6/1) grading down to dark yellowish orange $(10 Y R 6 / 6)$, grades to.... $.2-6$

Silt, clayey, very fine sandy, dense, stiff, yellowish gray $(5 Y 7 / 1)$

mottled dark yellowish orange (10YR 6/6), grades to $6-14$

Sand, very fine, silty, thixotropic, dark yellowish orange (10YR 6/6) $14-16$

Silt, clayey, very fine sandy, grayish yellow (5Y 7/4) grading down to yellowish gray $(5 Y 7 / 2)$ $16-29$

Sand, medium to coarse, angular to subangular, silty, yellowish orange (10YR 7/6) grading through pale grayish orange (10YR 8/4; 30-32 feet) to pale olive brown ( $5 Y 6 / 6)$, grades to $29-32$

Sand, coarse to very coarse, contains subround quartz granules and pebbles up to $5 \mathrm{~cm}$ in diameter, pale olive brown $(5 Y 6 / 6)$ $.32-34$

\section{Yorktown Formation (Zone 2)}

Sand, very fine, silty, shelly, greenish gray $(5 G Y 6 / 1)$, grades to..... $34-40$

Sand, very fine, sparsely shelly, dark greenish gray $(5 G 4 / 1)$ $.40-57$

Sand, fine to medium, round black-stained quartz pebbles up to

$3 \mathrm{~cm}$ in diameter abundant, dark greenish gray $(5 G 4 / 1)$ $.57-58$

\section{Eastern Carolina Slate Belt Rocks}

Saprolite, derived from banded biotite gneiss, medium greenish gray

$(5 G Y 7 / 1)$ rapidly grading to pale olive $(10 Y 6 / 2)$ $.58-61$
Base of Upper Bacons Castle Formation (Bahramsville Member):
+80 feet elevation
Base of Yorktown Formation (Zone 2):
+56 feet elevation

Bottomed in Eastern Carolina Slate Belt saprolite 
EN-03-2: 8.36 miles west of the east quadrangle border, 7.97 miles north of the south quadrangle border, northwest $1 / 9^{\text {th }}$ of map area (latitude $36.2405^{\circ} \mathrm{N}$, longitude $77.7362^{\circ} \mathrm{W}$ ). Surface elevation 152 feet.

\section{LITHOLOGY}

DEPTH IN FEET

\section{Lower Bacons Castle Formation, Varina Grove Member}

Sand, fine to medium with scattered coarse grains grading down to very fine to fine with scattered medium grains, silty, clayey, dark yellowish orange $(10 Y R 6 / 6)$ $0-7$

Silt, very fine sandy, clayey, dense, stiff, pale reddish brown (10R 5/4) mottled yellowish gray (5Y 7/2) grading down to reddish brown $(10 R 5 / 6)$ mottled yellowish gray $(5 Y 7 / 2)$ $.7-14$

\section{Eastern Carolina Slate Belt Rocks}

Saprolite, angular to very angular fine to medium quartz grains floating in a clay-silt matrix, local pods of kaolin present, reddish brown (10R 5/6) mottled pale yellowish gray (5Y 8/2) grading down to reddish brown $(10 R 5 / 6)$ mottled pale yellowish gray $(5 Y 8 / 2)$, dark gray (N3) and yellowish orange (10YR 7/6) $14-36$

Base of Lower Bacons Castle Formation (Varina Grove Member): +138 feet elevation

Bottomed in Eastern Carolina Slate Belt saprolite 


\section{GALATIA QUADRANGLE}

GA-02-1: 0.22 mile west of the east quadrangle border, 5.22 miles north of the south quadrangle border, east-central $1 / 9^{\text {th }}$ of map area (latitude $36.4508^{\circ} \mathrm{N}$, longitude $77.2539^{\circ} \mathrm{W}$ ). Surface elevation 90 feet.

\section{LITHOLOGY}

DEPTH IN FEET

Road fill, fine to coarse sand.

$.0-1$

\section{Upper Bacons Castle Formation, Bahramsville Member}

Sand, medium to coarse, poorly sorted, subround, silty, contains sparse quartz granules and pebbles up to $0.5 \mathrm{~cm}$ in diameter, very dark yellowish orange ( $5 Y R 5 / 6)$ grading down at 9 feet to very pale orange $(10 Y R 8 / 2)$. $1-11$

Sand, medium to coarse, silty, medium olive gray (5Y 4/2) $11-14$

\section{Chowan River Formation}

Silt, very fine sandy, clayey, finely micaceous, medium greenish gray $(5 G Y 5 / 1)$ $14-37$

Sand, very fine to fine, silty, thixotropic, medium greenish gray $(5 G Y 5 / 1)$. $37-48$

Sand, medium to coarse, medium greenish gray $(5 G Y 5 / 1)$ $.48-51$

Sand, fine to medium, subangular to subround, silty, clayey, medium greenish gray $(5 G Y 5 / 1)$ $.51-66$

No recovery, drilled crunchy so apparently gravel $.66-68$

\section{Indeterminate Formation}

Indurated bed, probably top of Cape Fear Formation at 68
Base of Upper Bacons Castle Formation (Bahramsville Member):
+76 feet elevation
Base of Chowan River Formation:
+22 feet elevation

Bottomed on Cape Fear Formation? 
GA-02-2: 5.99 miles west of the east quadrangle border, 3.98 miles north of the south quadrangle border, west-central $1 / 9^{\text {th }}$ of map area (latitude $36.4327^{\circ} \mathrm{N}$, longitude $77.3555^{\circ} \mathrm{W}$ ). Surface elevation 120 feet.

\section{LITHOLOGY}

DEPTH IN FEET

\section{Upper Bacons Castle Formation, Bahramsville Member}

Sand, very fine to fine, silty, slightly clayey, dark yellowish orange

$(10 Y R$ 6/6) $0-4$

Sand, very fine to fine, silty, clayey, stiff, pale yellowish gray $(5 Y 8 / 2)$ mottled moderate reddish brown $(10 R 4 / 6)$ $4-6$

Silt, very fine to fine sandy, clayey, finely micaceous, pale yellowish gray $(5 Y 8 / 2)$ mottled moderate reddish brown $(10 R$ 4/6) $6-11$

Sand, very fine to fine, very silty, slightly clayey, dark yellowish orange $(10 Y R 6 / 6)$, grades to $11-32$

Sand, medium to coarse, dark yellowish orange (10YR 6/6), grades to. $.32-39$

Sand, medium to coarse, contains scattered round quartz pebbles up to $2.5 \mathrm{~cm}$ in diameter, dark yellowish orange $(10 Y R$ 6/6) $39-49$

Sand, medium to very coarse, slightly silty, very dark yellowish orange $(10 Y R 5 / 6)$ $49-52$

\section{Yorktown Formation (Zone 2)}

Sand, very fine, silty, clayey, grading down to silt, clayey, very fine sandy, finely micaceous, light brown (5YR 5/6) rapidly grading down to medium greenish gray $(5 G 5 / 1)$ $52-56$

Sand, very fine grading down to very fine to fine, silty, sparsely shelly, medium greenish gray $(5 G Y 5 / 1)$ $.56-84$

Sand, fine to medium, silty, contains abundant shell fragments and phosphate pellets, medium greenish gray $(5 G Y 5 / 1)$ $.84-85$

\section{Eastover Formation}

Sand, fine, well sorted, silty, very clayey, dense, contains sparse barnacle elements, medium greenish gray $(5 G 5 / 1)$, grades to. $.85-88$

Sand, fine, well sorted, silty, dark greenish gray (5GY 4/1) $88-103$

Sand, medium to coarse, contains black-stained quartz pebbles up to $1 \mathrm{~cm}$ in diameter, dark greenish gray $(5 G Y 4 / 1)$ $103-104$ 


\section{Cape Fear Formation}

Clay, silty, very fine sandy, stiff, dense, greenish gray $(5 G 6 / 1)$ grading rapidly to moderate reddish brown $(10 R 4 / 6)$ mottled

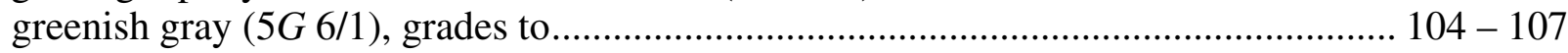

Sand, fine, silty, clayey, coarsely micaceous, stiff, very dense, moderate reddish brown $(10 R 4 / 6)$ mottled greenish gray $(5 G 6 / 1)$...... $107-111$

Base of Upper Bacons Castle Formation (Bahramsville Member): $\quad$ +68 feet elevation Base of Yorktown Formation (Zone 2):

Base of Eastover Formation:

+35 feet elevation

+16 feet elevation

Bottomed in Cape Fear Formation 
GA-03-3: 0.39 mile west of the east quadrangle border, 4.33 miles north of the south quadrangle border, east-central $1 / 9^{\text {th }}$ of map area (latitude $36.4379^{\circ} \mathrm{N}$, longitude $77.2569^{\circ} \mathrm{W}$ ). Surface elevation 119 feet.

\section{LITHOLOGY}

DEPTH IN FEET

\section{Upper Bacons Castle Formation, Moorings Member}

Sand, upper fine to lower medium, well sorted, clean, pale grayish

orange (10YR $8 / 4)$, grades rapidly to $0-3$

\section{Upper Bacons Castle Formation, Bahramsville Member}

Sand, fine to medium, clayey, dark yellowish orange $(10 Y R 6 / 6)$ $3-6$

Sand, fine to coarse, poorly sorted, silty, clayey, reddish brown $(10 R 4 / 6)$ mottled very pale orange $(10 Y R 8 / 2)$ grading down through dark yellowish brown (10YR 4/6; 8-9 feet) to moderate yellowish brown $(10 Y R$ 5/6) $6-10$

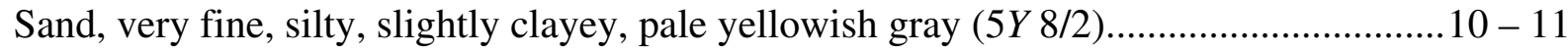

Base of Upper Bacons Castle Formation (Moorings Member): +116 feet elevation

Bottomed in Upper Bacons Castle Formation (Bahramsville Member) 


\section{HALIFAX OUADRANGLE}

HA-02-1: 5.30 miles west of the east quadrangle border, 7.57 miles north of the south quadrangle border, northwest $1 / 9^{\text {th }}$ of map area (latitude $36.3600^{\circ} \mathrm{N}$, longitude $77.5949^{\circ} \mathrm{W}$ ). Surface elevation 107 feet.

\section{LITHOLOGY}

DEPTH IN FEET

\section{Lower Bacons Castle Formation, Varina Grove Member}

Sand, dominantly medium ranging up to coarse, slightly silty, yellowish orange (10YR 7/6) $.0-1$

Sand, medium to very coarse, contains subround quartz granules and rare round quartz pebbles up to $1 \mathrm{~cm}$ in diameter, silty, slightly clayey, moderate orange (10YR 5/6) grading down to pale grayish orange (10YR 8/4) at 11 feet $1-14$

Sand, coarse to very coarse, yellowish brown (10YR 5/2) mottled moderate orange (10YR 5/6) $.14-15$

\section{Yorktown Formation (Zone 2)}

Silt, very clayey, greasy, yellowish gray (5Y 7/2) streaked yellowish brown (10YR 5/2) $.15-16$

Silt, clayey, very fine sandy, finely micaceous, round quartz pebbles up to $3 \mathrm{~cm}$ in diameter abundant in basal foot, medium greenish gray $(5 G 5 / 1)$ $16-36$

\section{Eastover Formation}

Sand, fine, slightly silty, soft, upper 3 feet has burrows filled with lithology from above, medium greenish gray $(5 G 5 / 1)$ $.36-45$

Sand, fine to medium, contains chalky shells, angular to subangular quartz pebbles up to $2 \mathrm{~cm}$ in diameter common at base, medium greenish gray $(5 G 5 / 1)$ $45-47$

\section{Eastern Carolina Slate Belt Rocks}

Saprolite, abundant coarse angular quartz grains and sand-size pods of kaolin floating in clay matrix, medium greenish gray (5GY 7/1) $.47-51$
Base of Lower Bacons Castle Formation (Varina Grove Member): Base of Yorktown Formation (Zone 2):
+92 feet elevation
Base of Eastover Formation:
+71 feet elevation
+60 feet elevation

Bottomed in Eastern Carolina Slate Belt saprolite 
HA-02-2: 1.00 mile west of the east quadrangle border, 6.67 miles north of the south quadrangle border, northeast $1 / 9^{\text {th }}$ of map area (latitude $36.3452^{\circ} \mathrm{N}$, longitude $77.5174^{\circ} \mathrm{W}$ ). Surface elevation 67 feet.

\section{LITHOLOGY}

DEPTH IN FEET

\section{Older Alluvium}

Sand, dominantly fine but with scattered subround medium to coarse grains, silty, pale yellowish brown (10YR 7/2) grading down to moderate brown $(5 Y R 4 / 6)$ $0-1$

Sand, grades downward from fine to fine-medium, silty and micaceous, moderate brown (5YR 4/6), more silty and slightly clayey below 6 feet, at base grades rapidly to $1-18$

Sand, coarse to very coarse, subround to subangular, slightly silty, loose, contains round quartz pebbles up to $1 \mathrm{~cm}$ diameter, moderate orange (10YR 5/6) grading down to pale grayish orange (10YR 8/4); pebbles near base up to $4 \mathrm{~cm}$ diameter. $.18-35$

\section{Windsor Formation?}

Sand, fine, well sorted, silty, loose, dark orange (10YR 3/6) grading down to olive $(10 Y 5 / 2)$. $35-38$

Silt, clayey, pale olive gray $(5 Y 7 / 1)$, grades to $.38-46$

Silt, clayey, greasy and micaceous, medium greenish gray $(5 G 5 / 1)$ $46-67$

Silt, clayey, greasy and micaceous, grayish black ( $N 2)$ $67-69$

Silt, clayey, greasy and micaceous, medium greenish gray $(5 G 5 / 1)$, grades rapidly to. $.69-77$

Sand, fine to coarse, subround, poorly sorted at top and better sorted downward, silty, medium greenish gray $(5 G Y 5 / 1)$ $.77-81$

\section{Eastern Carolina Slate Belt Rocks}

Saprolite, angular quartz in clay matrix, reddish brown (10R 3/6) mottled yellowish gray $(5 Y 7 / 2)$ grading through pale reddish brown (10R 6/4; 82-84 feet) to pale reddish brown (10R 6/4) mottled pale yellowish gray $(5 Y 8 / 2)$ $.81-86$ 
Base of older alluvium: $\quad+32$ feet elevation

Base of Windsor Formation?: -14 feet elevation

Bottomed in Eastern Carolina Slate Belt saprolite 
HA-02-3: 3.48 miles west of the east quadrangle border, 2.96 miles north of the south quadrangle border, central $1 / 9^{\text {th }}$ of map area (latitude $36.2930^{\circ} \mathrm{N}$, longitude $77.5604^{\circ} \mathrm{W}$ ). Surface elevation 74 feet.

\section{LITHOLOGY}

DEPTH IN FEET

\section{Charles City Formation}

Silt, clayey, very fine sandy, light olive gray (5Y 6/1) mottled dark yellowish orange $(10 Y R$ 6/6) (0-1 foot) grading down to light greenish gray $(5 G 7 / 1)$ mottled dark yellowish orange $(10 Y R 6 / 6)$ $.0-21$

Sand, very fine to fine, silty, clayey, very dark yellowish orange $(10 Y R 5 / 6)$ $21-32$

Sand, fine to medium, very silty, slightly clayey, soft, round quartz pebbles up to $2.5 \mathrm{~cm}$ in diameter present in basal two feet, very dark yellowish orange $(10 Y R 5 / 6)$ $32-38$

Sand, medium to very coarse, contains quartz granules and pebbles, grayish orange (10YR 7/4); saprolite clay ball present at 49-50 feet composed of kaolin and angular quartz, very light gray $(N 8)$ streaked moderate reddish brown $(10 R 4 / 6)$ $38-52$

\section{Eastern Carolina Slate Belt Rocks}

Saprolite, angular quartz grains floating in clay matrix, dusky yellow (5Y 6/4) streaked moderate reddish brown (10R 4/6) $52-56$

Base of Charles City Formation: +22 feet elevation

Bottomed in Eastern Carolina Slate Belt saprolite 
HA-02-4: 0.37 mile west of the east quadrangle border, 0.10 mile north of the south quadrangle border, southeast $1 / 9^{\text {th }}$ of map area (latitude $36.2518^{\circ} \mathrm{N}$, longitude $77.5095^{\circ} \mathrm{W}$ ). Surface elevation 111 feet.

\section{LITHOLOGY}

DEPTH IN FEET

\section{Upper Bacons Castle Formation, Bahramsville Member}

Silt, very clayey, very fine sandy, slightly micaceous, stiff, dense, dark yellowish orange $(10 Y R 6 / 6)$ $0-1$

Silt, very clayey, very fine sandy, slightly micaceous, stiff, dense, grading down to sand, very fine, silty, grayish orange (10YR 7/4), grades to $1-6$

Sand, fine grading down to fine to medium, clean, contains $1-2 \%$ very fine to fine dark heavy mineral grains, yellowish orange (10YR 7/6) grading down to light grayish orange (10YR 8/4) $6-11$

Sand, medium to coarse grading back and forth with coarse to very coarse three times, light grayish orange (10YR 8/4) grading down at 23 feet to pale grayish orange $(10 Y R$ 8/3) . $.11-31$

Sand, medium to very coarse, silty, contains quartz pebbles up to $1 \mathrm{~cm}$ in diameter and clayballs of Yorktown lithology, dark grayish orange $(10 Y R 6 / 4)$ $31-41$

\section{Yorktown Formation (Zone 2)}

Sand, very fine to fine, silty, clayey, medium greenish gray $(5 G Y 5 / 1)$, grades to $41-45$

Sand, fine, silty, clayey, shelly (including Chesapecten), medium greenish gray $(5 G Y 5 / 1)$. $.45-61$

Base of Upper Bacons Castle Formation (Bahramsville Member): +70 feet elevation Bottomed in Yorktown Formation (Zone 2) 
HA-02-5: 5.62 miles west of the east quadrangle border, 0.87 mile north of the south quadrangle border, southwest $1 / 9^{\text {th }}$ of map area (latitude $36.2628^{\circ} \mathrm{N}$, longitude $77.6003^{\circ} \mathrm{W}$ ). Surface elevation 112 feet.

\section{LITHOLOGY}

DEPTH IN FEET

\section{Upper Bacons Castle Formation, Bahramsville Member}

Sand, fine to coarse, poorly sorted, loose, grayish orange (10YR 7/2), grades to $0-3$

Sand, fine to medium, silty, dense, dark yellowish orange $(10 Y R 6 / 6)$ $3-6$

Sand, fine to coarse, subangular to subround, slightly silty, slightly clayey, moderate reddish brown $(10 R 4 / 6)$ mottled pale yellowish gray $(5 Y 8 / 2)$ $6-11$

\section{Yorktown Formation (Zone 2)}

Sand, very fine, silty, clayey, sticky, dark grayish orange (10YR 6/4) grading through dark grayish orange (10YR 6/4) mottled medium olive gray $(5 Y 5 / 1 ; 15-17$ feet) to medium greenish gray $(5 G 5 / 1)$, grades to $11-21$

Silt, clayey, very fine sandy, very sticky, medium greenish gray $(5 G 5 / 1) \ldots \ldots \ldots \ldots \ldots \ldots . . . . .21-38$

Silt, clayey, very fine sandy, shelly (including oysters and Mulinia sp.), medium greenish gray $(5 G 5 / 1)$ $.38-40$

Sand, very fine, silty, clayey, micaceous, medium greenish gray $(5 G 5 / 1) \ldots$ $.40-41$

Base of Upper Bacons Castle Formation (Bahramsville Member): +101 feet elevation Bottomed in Yorktown Formation (Zone 2) 
HA-02-6: 6.63 miles west of the east quadrangle border, 4.31 miles north of the south quadrangle border, west-central $1 / 9^{\text {th }}$ of map area (latitude $36.3124^{\circ} \mathrm{N}$, longitude $77.6181^{\circ} \mathrm{W}$ ). Surface elevation 125 feet.

\section{LITHOLOGY}

DEPTH IN FEET

\section{Upper Bacons Castle Formation, Bahramsville Member}

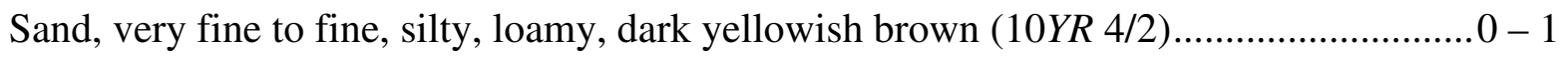

Sand, fine, silty, slightly micaceous, medium olive gray $(5 Y 4 / 2)$

grading down in basal foot to pale yellowish brown $(10 Y R 6 / 2)$ $1-6$

Silt, clayey, very fine to medium sandy, basal foot contains abundant round quartz pebbles up to $1 \mathrm{~cm}$ in diameter, pale olive $(10 Y 6 / 2)$

mottled pale brown $(5 Y R$ 5/2) and dark yellowish orange $(10 Y R 6 / 6)$ $6-11$

\section{Yorktown Formation (Zone 2)}

Silt, very fine sandy, clayey, yellowish orange (10YR 7/6) grading down to yellowish gray $(5 Y 7 / 2)$, grades to $11-20$

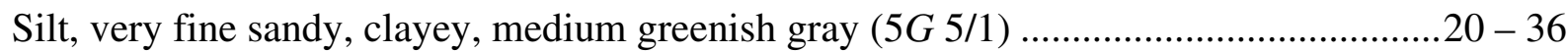

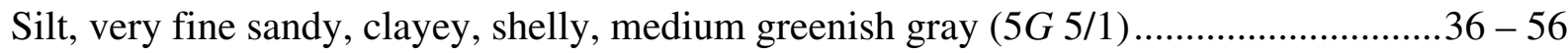

Base of Upper Bacons Castle Formation (Bahramsville Member): +114 feet elevation

Bottomed in Yorktown Formation (Zone 2) 
HA-02-7: 4.82 miles west of the east quadrangle border, 4.42 miles north of the south quadrangle border, west-central $1 / 9^{\text {th }}$ of map area (latitude $36.3147^{\circ} \mathrm{N}$, longitude $77.5856^{\circ} \mathrm{W}$ ). Surface elevation 112 feet.

\section{LITHOLOGY}

DEPTH IN FEET

\section{Upper Bacons Castle Formation, Bahramsville Member}

Sand, medium to coarse, clean, dark yellowish brown (10YR 4/2)

grading down to grayish orange (10YR 7/4) $0-1$

Sand, medium to very coarse, subangular to subround, silty, slightly clayey, contains round quartz pebbles up to $1 \mathrm{~cm}$ in diameter, yellowish orange (10YR 7/6) grading down to pale grayish orange (10YR 8/4) $1-13$

\section{Yorktown Formation (Zone 2)}

Silt, clayey, very fine sandy, yellowish gray $(5 Y 7 / 2)$ mottled yellowish orange $(10 Y R 7 / 6)$, grades rapidly to..... $13-17$

Silt, clayey, very fine sandy, finely micaceous, medium greenish gray $(5 G 5 / 1)$ $17-60$

Silt, clayey, very fine sandy, finely micaceous, shelly, medium greenish gray $(5 G 5 / 1)$ $60-72$

\section{Eastern Carolina Slate Belt Rocks}

Saprolite, medium to granule-size angular quartz in clayey silt matrix, light yellowish gray $(5 Y 8 / 2)$ $72-76$

$\begin{array}{ll}\text { Base of Upper Bacons Castle Formation (Bahramsville Member): } & +99 \text { feet elevation } \\ \text { Base of Yorktown Formation (Zone 2): } & +40 \text { feet elevation }\end{array}$

Bottomed in Eastern Carolina Slate Belt saprolite 
HA-02-8: 0.37 mile west of the east quadrangle border, 1.03 miles north of the south quadrangle border, southeast $1 / 9^{\text {th }}$ of map area (latitude $36.2649^{\circ} \mathrm{N}$, longitude $77.5063^{\circ} \mathrm{W}$ ). Surface elevation 60 feet.

\section{LITHOLOGY}

DEPTH IN FEET

\section{Older Alluvium}

Sand, very fine to fine, silty, moderate brown (5YR 4/6) grading down to dark yellowish brown $(10 Y R 4 / 6)$ $0-1$

Sand, fine grading down to fine to medium, silty, dark yellowish brown $(10 Y R$ 4/6). $1-4$

Sand, medium, contains quartz pebbles up to $3 \mathrm{~cm}$ in diameter, dark grayish orange $(10 Y R 6 / 4)$ $4-6$

Gravel, quartz clasts up to $3 \mathrm{~cm}$ in diameter, medium to coarse sand matrix, pale yellowish brown $(10 Y R 6 / 2)$ $6-12$

Gravel, quartz clasts up to $3 \mathrm{~cm}$ in diameter, coarse to very coarse sand matrix, grayish orange (10YR 7/4). $.12-21$

Sand, coarse to very coarse, contains sparse quartz pebbles up to

$2 \mathrm{~cm}$ in diameter, grayish orange $(10 Y R 7 / 4)$ $.21-40$

\section{Windsor Formation?}

Sand, very fine, silty, very micaceous, contains fragments of carbonized wood, dark olive gray (5Y3/1) $40-41$

Sand, fine to medium, micaceous, grayish orange (10YR 7/4) . $.41-51$

Silt, clayey, very fine sandy, woody, olive gray (5Y 4/1) mottled grayish black $(N 2)$. $51-51.5$

Sand, fine to medium, micaceous, grayish orange (10YR 7/4) $51.5-52$

Silt, clayey, very fine sandy, micaceous, soft, medium greenish gray $(5 G Y 5 / 1)$ $.52-53$

\section{Clubhouse Formation}

Sand, fine to medium, silty, micaceous, dense but not sticky, very kaolinitic, light greenish gray $(5 G Y 7 / 1)$ $.53-61$

\footnotetext{
Base of older alluvium: $\quad+20$ feet elevation

Base of Windsor Formation?: $\quad+7$ feet elevation

Bottomed in Clubhouse Formation
} 


\section{HOBGOOD QUADRANGLE}

HO-02-1: 2.79 miles west of the east quadrangle border, 1.62 miles north of the south quadrangle border, south-central $1 / 9^{\text {th }}$ of map area (latitude $36.0237^{\circ} \mathrm{N}$, longitude $77.4242^{\circ} \mathrm{W}$ ). Surface elevation 70 feet.

\section{LITHOLOGY}

DEPTH IN FEET

\section{Windsor Formation}

Sand, fine to medium, silty, clayey, medium yellowish brown $(10 Y R 5 / 4)$ grading down to dark yellowish orange $(10 Y R 6 / 6)$ $0-1$

Sand, fine to medium, silty, clayey, moderate orange (10YR 5/6) sparsely mottled light yellowish gray $(5 Y 8 / 2)$ $1-6$

Sand, fine to medium, silty, soft, interbedded with 4-6 inch-thick layers of sand, very fine, silty, clayey, moderate orange (10YR 5/6) sparsely mottled light yellowish gray $(5 Y 8 / 2)$ $6-20$

Sand, fine to medium, clayey, medium greenish gray $(5 G Y 5 / 1)$ $20-21$

\section{Yorktown Formation (Zone 2)}

Sand, very fine, silty, interbedded with silt, very fine sandy, clayey, sparsely shelly below 28 feet, medium greenish gray $(5 G Y 5 / 1)$ $.21-39$

No recovery, crunchy drilling, probably a shell bed $39-41$

Sand, fine, silty, soft, sparsely shelly (including Turritella $\mathrm{sp.}$

and pectenids), medium greenish gray $(5 G Y 5 / 1)$ $41-47$

Sand, fine to medium, quartz granules abundant, sparsely shelly, medium greenish gray $(5 G Y 5 / 1)$. $47-48$

\section{Clubhouse Formation}

Sand, very fine to fine, clayey, silty, finely micaceous, dense, tough drilling, pale olive $(10 Y 6 / 2)$, grading down to sand, very fine with scattered medium and coarse grains, light olive brown $(5 Y 5 / 4)$ mottled moderate olive brown (5Y 4/4) $48-56$

$\begin{array}{ll}\text { Base of Windsor Formation: } & +49 \text { feet elevation } \\ \text { Base of Yorktown Formation (Zone } 2): & +22 \text { feet elevation }\end{array}$

Bottomed in Clubhouse Formation 
HO-03-2: 6.78 miles west of the east quadrangle border, 6.60 miles north of the south quadrangle border, northwest $1 / 9^{\text {th }}$ of map area (latitude $36.0959^{\circ} \mathrm{N}$, longitude $77.4958^{\circ} \mathrm{W}$ ). Surface elevation 107 feet.

\section{LITHOLOGY}

DEPTH IN FEET

\section{Upper Bacons Castle Formation, Bahramsville Member}

Sand, fine, well sorted, silty, contains about $1 \%$ very fine to fine dark heavy mineral grains, silty, dark yellowish brown (10YR 4/4) grading down through light yellowish brown (10YR 6/4) and light grayish orange (10YR 8/4) to dark yellowish orange (10YR 6/6) $.0-1$

Sand, fine grading down to very fine, silty, clayey, dark yellowish orange $(10 Y R 6 / 6)$ $1-3$

Silt, very fine sandy, clayey, light reddish brown $(10 R 5 / 6)$ mottled light olive gray $(5 Y 5 / 2)$ grading down to light olive gray $(5 Y 5 / 2)$ mottled moderate reddish brown $(10 R 4 / 6)$ $3-6$

Silt, very fine sandy, clayey, dark orange (10YR 4/6) mottled light olive gray $(5 Y 5 / 2)$, moderate reddish brown $(10 R 4 / 6)$, and dark yellowish orange $(10 Y R 6 / 6)$ $6-11$

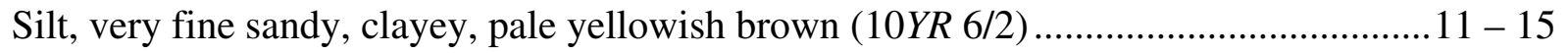

Sand, very fine grading down to very fine to fine, silty, clayey, dark yellowish gray $(5 Y 6 / 2)$ $15-23$

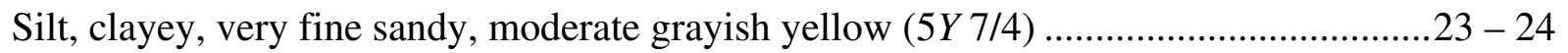

Sand, fine, well sorted, silty, micaceous, dark yellowish gray $(5 Y 6 / 2) \ldots \ldots \ldots \ldots \ldots \ldots \ldots \ldots . . . . . . . . . . . . .24-25$

\section{Yorktown Formation (Zone 2)}

Sand, very fine, silty, clayey, yellowish orange $(10 Y R 7 / 6)$ grading at 27 feet to medium olive gray $(5 Y 5 / 1)$ $.25-31$

Base of Upper Bacons Castle Formation (Bahramsville Member): +82 feet elevation Bottomed in Yorktown Formation (Zone 2) 
HO-03-3: 7.00 miles west of the east quadrangle border, 0.95 mile north of the south quadrangle border, southwest $1 / 9^{\text {th }}$ of map area (latitude $36.0139^{\circ} \mathrm{N}$, longitude $77.4995^{\circ} \mathrm{W}$ ). Surface elevation 97 feet.

\section{LITHOLOGY}

DEPTH IN FEET

\section{Upper Bacons Castle Formation, Bahramsville Member}

Sand, very fine to fine, silty, clayey, grayish orange (10YR 7/4) grading down to dark yellowish orange $(10 Y R 6 / 6)$ $0-1$

Sand, very fine to fine grading downward to very fine, dark yellowish orange (10YR 6/6) mottled yellowish gray (5Y 8/1) and pale reddish brown $(10 R 5 / 6)$, sharp basal contact. $1-7$

Sand, medium to coarse, subangular to subround, silty, clayey, yellowish orange $(10 Y R 7 / 8)$ $.7-11$

Sand, medium to coarse, silty, yellowish orange (10YR 7/6), interbedded with sand, very fine, silty and clayey, yellowish gray $(5 Y 7 / 2)$ $.11-14.5$

Sand, coarse to very coarse, silty, clayey, dark yellowish brown (10YR 4/2) $14.5-15$

\section{Yorktown Formation (Zone 2)}

Sand, very fine, silty, clayey, yellowish orange (10YR 7/6) grading through grayish yellow $(5 Y 7 / 4 ; 16-16.5$ feet) and greenish gray (5G 5/1; 16.5-17 feet) and dark grayish orange (10YR 6/4; 17-23 feet) to medium greenish gray $(5 G 5 / 1)$. $15-26$

Base of Upper Bacons Castle Formation (Bahramsville Member): +82 feet elevation Bottomed in Yorktown Formation (Zone 2) 
HO-03-4: 3.72 miles west of the east quadrangle border, 7.88 miles north of the south quadrangle border, north-central $1 / 9^{\text {th }}$ of map area (latitude $36.1000^{\circ} \mathrm{N}$, longitude $77.4409^{\circ} \mathrm{W}$ ). Surface elevation 95 feet.

\section{LITHOLOGY}

DEPTH IN FEET

\section{Windsor Formation}

Sand, fine, well sorted, silty, grayish orange (10YR 7/4) grading down to dark yellowish orange (10YR 6.5/6). $0-1$

Silt, clayey, very fine sandy, stiff, dark yellowish orange (10YR 6/6) mottled yellowish gray $(5 Y 7 / 2)$ grading down to yellowish gray (5Y 7/2) mottled dark yellowish orange (10YR 6/6) and reddish brown $(10 R 5 / 6)$ $1-6$

Silt, clayey, very fine sandy, yellowish gray (5Y 7/2) mottled reddish brown $(10 R 5 / 6)$ $6-9$

Sand, very fine to fine, silty, dark yellowish orange (10YR 6/6) grading rapidly down to light brown $(5 Y R 5 / 6)$ mottled pale yellowish orange $(10 Y R$ 8/6) $9-11$

Sand, fine to medium, silty, yellowish orange (10YR 7/6), grades to. $11-19$

Sand, medium to coarse, silty, pale grayish orange (10YR 8/4) grading through yellowish orange (10YR 7/6) to dark yellowish brown $(10 Y R 4 / 6)$ $19-24$

Sand, coarse to very coarse, granular, yellowish brown $(10 Y R 5 / 2)$ $24-25$

\section{Upper Bacons Castle Formation, Bahramsville Member}

Sand, very fine, silty, clayey, contains scattered medium and coarse grains, yellowish gray $(5 Y 7 / 2)$ mottled grayish brown $(5 Y R 6 / 2)$ grading by 25.5 feet to light brownish gray $(5 Y R 6 / 1)$ $.25-31$

Sand, fine to medium, silty, soft, thixotropic, dark grayish orange (10YR 6/4), grades to..... $31-36$

Sand, medium to coarse, soft, silty, dark grayish orange (10YR 6/4) $.36-38$

\section{Yorktown Formation (Zone 2)}

Sand, very fine, silty, clayey, dark grayish orange (10YR 6/4) grading to medium dark gray $(N 4)$.... $38-40$ 
Sand, very fine to fine, silty, shelly, medium greenish gray

$(5 G Y 5 / 1)$, grades to $40-46$

Sand, fine, silty, shelly, medium greenish gray ( $5 G Y$ 5/1), grades to................................46 - 61

Sand, fine to medium, contains abundant dark round quartz pebbles

up to $3 \mathrm{~cm}$ in diameter, sparsely shelly, olive $(10 Y 5 / 2) \ldots \ldots \ldots \ldots \ldots \ldots \ldots \ldots \ldots \ldots \ldots \ldots \ldots \ldots \ldots \ldots . . . . . .61-63$

\section{Clubhouse Formation}

Sand, very fine to medium, subangular, silty, clayey, stiff, dense, pale olive gray $(5 Y 7 / 1)$ $63-66$

Base of Windsor Formation:

+70 feet elevation

Base of Upper Bacons Castle Formation (Bahramsville Member): Base of Yorktown Formation (Zone 2):

+57 feet elevation +32 feet elevation

Bottomed in Clubhouse Formation 


\section{JACKSON QUADRANGLE}

JA-02-1: 3.89 miles west of the east quadrangle border, 2.88 miles north of the south quadrangle border, central $1 / 9^{\text {th }}$ of map area (latitude $36.4169^{\circ} \mathrm{N}$, longitude $77.4442^{\circ} \mathrm{W}$ ). Surface elevation 105 feet.

\section{LITHOLOGY}

DEPTH IN FEET

\section{Upper Bacons Castle Formation, Bahramsville Member}

Sand, fine, well sorted, slightly silty, yellowish brown (10YR 5/2)

grading down at 1 foot to grayish orange (10YR 7/4), grades to $0-1$

Sand, fine, well sorted, silty, clayey, stiff, dark yellowish orange (10YR 6/6) mottled pale yellowish gray $(5 Y 8 / 4)$.... $1-11$

Sand, very fine to fine, very silty, very clayey, grading down to silt, very clayey, very fine to fine sandy, dark yellowish orange (10YR 6/6) mottled pale yellowish gray (5Y 8/4) to 30 feet and then greenish gray $(5 G Y 6 / 1)$ $11-30$

Sand, medium to coarse, subangular, silty, brownish gray $(5 Y R 4 / 1)$ $30-31$

\section{Yorktown Formation (Zone 2)}

Sand, very fine, silty, grading through silt, very fine sandy, and then back to sand, very fine, silty, olive gray (5Y 4/1) grading down at 44 feet to medium greenish gray $(5 G Y 5 / 1)$, shelly below 34 feet $31-51$

\section{Eastover Formation}

Sand, fine grading down through fine to medium to medium at base, well sorted, silty, sparsely shelly, round quartz pebbles up to $2.5 \mathrm{~cm}$ in diameter at base, dark greenish gray $(5 G Y 4 / 1)$. $.51-80$

\section{Clubhouse Formation}

Clay, silty, very fine to fine sandy, dense, medium greenish gray (5GY 7/1) grading at 82 feet depth to moderate reddish brown $(10 R$ 4/6) mottled light olive brown (5Y 5/4) $80-91$
Base of Upper Bacons Castle Formation (Bahramsville Member): Base of Yorktown Formation (Zone 2):
Base of Eastover Formation:
+74 feet elevation
+54 feet elevation
+25 feet elevation

Bottomed in Clubhouse Formation 


\section{KELFORD QUADRANGLE}

KE-03-1: 2.98 miles west of the east quadrangle border, 4.77 miles north of the south quadrangle border, central $1 / 9^{\text {th }}$ of map area (latitude $36.1930^{\circ} \mathrm{N}$, longitude $77.1779^{\circ} \mathrm{W}$ ). Surface elevation 73 feet.

\section{LITHOLOGY}

DEPTH IN FEET

\section{Charles City Formation}

Sand, very fine, silty, clayey, stiff, dense, pale yellowish brown $(10 Y R 6 / 2)$ grading down to dark yellowish orange (10YR 6/6) mottled dark yellowish gray $(5 Y 6 / 2)$, grades to $.0-1$

Sand, very fine, silty, clayey, stiff, dense, medium brownish gray $(5 Y R$ 5/1) streaked dark yellowish brown (10YR 4/6), grades to $1-6$

Sand, very fine, silty, slightly clayey, yellowish gray (5Y 7/2) mottled moderate yellowish brown (10YR 5/6), grading at 11 feet to dusky yellow (5Y 6/4) mottled moderate yellowish brown $(10 Y R 5 / 6)$ $6-11$

Sand, fine, silty, clayey, pale olive (10Y 6/2) grading down to greenish gray $(5 G 6 / 1)$. $11-17$

Sand, fine grading through fine to medium (20-24 feet) to medium to coarse, silty, soft, thixotropic, pale olive $(10 Y 6 / 2)$ $17-31$

Sand, medium to very coarse, subangular, contains abundant granules and subround to round quartz pebbles up to $1 \mathrm{~cm}$ in diameter, medium greenish gray $(5 G Y 5 / 1)$ $31-37$

\section{Yorktown Formation (Zone 2)}

Sand, very fine to fine, silty, clayey, sparsely shelly below 41 feet, dark greenish gray $(5 G 4 / 1)$ $37-45$

Sand, very fine to fine, silty, very shelly, dark greenish gray $(5 G 4 / 1) \ldots \ldots \ldots \ldots \ldots \ldots \ldots \ldots \ldots . . . .45-48$

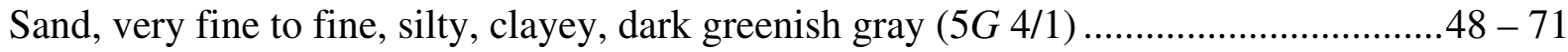

Base of Charles City Formation: +36 feet elevation

Bottomed in Yorktown Formation 


\section{MURFREESBORO OUADRANGLE}

MU-02-1: 1.45 miles west of the east quadrangle border, 3.85 miles north of the south quadrangle border, east-central $1 / 9^{\text {th }}$ of map area (latitude $36.4309^{\circ} \mathrm{N}$, longitude $77.0257^{\circ} \mathrm{W}$ ). Surface elevation 42 feet.

\section{LITHOLOGY}

DEPTH IN FEET

\section{Chuckatuck Formation}

Sand, very fine, silty, clayey, stiff, yellowish gray (5Y 7/2) and dusky

yellow (5Y 6/4)

$0-1$

Silt, clayey, very fine sandy, stiff, dense, dark yellowish gray $(5 Y 6 / 2)$

sparsely mottled dark yellowish orange (10YR 6/6), grades to $1-9$

Sand, very fine to fine, micaceous, silty, clayey dark yellowish gray (5Y 6/2) mottled dark yellowish orange (10YR 6/6) $9-11$

Sand, very fine to fine with scattered grains of medium and coarse, silty, clayey, finely micaceous, dark yellowish gray $(5 Y 6 / 2)$ mottled dark grayish yellow (5Y 7/4) grading in basal foot to dark yellowish orange $(10 Y R 6 / 6)$ $11-25$

Sand, fine, well sorted, silty, sparsely micaceous, contains $1-2 \%$ very fine to fine dark heavy mineral grains, greenish gray $(5 G 6 / 1)$ $.25-35$

Sand, medium to coarse grading down to coarse to very coarse, subangular to subround, slightly silty, contains round quartz granules, light greenish gray $(5 G 7 / 1)$ $35-45$

\section{Yorktown Formation (Zone 2)}

Sand, fine to medium, silty, clayey, very shelly (including abundant Mulinia sp. and oysters), rare fragments of carbonized wood, medium greenish gray $(5 G Y 5 / 1)$ $45-58$

Gravel, crunchy drilling, a few subangular to subround quartz pebbles $2.5-5 \mathrm{~cm}$ in diameter retrieved but otherwise no recovery $.58-60$

\section{Eastover Formation?}

Lithified bed, very hard, nearly impenetrable, went nine inches in fifteen minutes and made almost no recovery except for a wisp of pale yellowish gray $(5 Y 9 / 1)$ silt. $.60-61$ 
Base of Chuckatuck Formation: $\quad-3$ feet elevation

Base of Yorktown Formation (Zone 2): $\quad-18$ feet elevation

Bottomed in Eastover Formation? 
MU-02-2: 5.72 miles west of the east quadrangle border, 6.65 miles north of the south quadrangle border, west-central $1 / 9^{\text {ths }}$ of map area (latitude $36.4567^{\circ} \mathrm{N}$, longitude $77.1018^{\circ} \mathrm{W}$ ). Surface elevation 80 feet.

\section{LITHOLOGY}

DEPTH IN FEET

\section{Windsor Formation}

Sand, fine to coarse, poorly sorted, silty, clayey, very dark yellowish orange $(10 Y R 5 / 6)$, grades to $0-4$

Sand, fine, well sorted, silty, very dark yellowish orange (10YR 5/6), grades to $4-8$

Sand, fine to medium, poorly sorted, subangular, medium yellowish orange $(10 Y R 7 / 6)$ $.8-11$

Sand, very fine to fine, very silty, slightly clayey, slightly micaceous, medium yellowish orange (10YR 7/6). $11-22$

Sand, fine, well sorted, silty, medium yellowish orange (10YR 7/6) grading through moderate yellowish brown (10YR 5/4) (27-32 feet) to yellowish orange $(10 Y R 7 / 6)$, grades to $22-33$

Sand, medium to coarse, contains scattered round quartz granules, very dark yellowish orange (10YR 5/6) $33-35$

\section{Yorktown Formation (Zone 2)}

Silt, clayey, very fine sandy, shelly below 38 feet (mostly Mulinia sp.), medium greenish gray $(5 G 5 / 1)$ $35-61$

Base of Windsor Formation: +45 feet elevation

Bottomed in Yorktown Formation (Zone 2) 
MU-02-3: 0.81 mile west of the east quadrangle border, 4.77 miles north of the south quadrangle border, east-central $1 / 9^{\text {th }}$ of map area (latitude $36.4442^{\circ} \mathrm{N}$, longitude $77.0141^{\circ} \mathrm{W}$ ). Surface elevation 51 feet.

\section{LITHOLOGY}

DEPTH IN FEET

\section{Chuckatuck Formation (barrier sand facies)}

Sand, fine, well sorted, loose, yellowish orange (10YR 7/6) $.0-1$

Sand, fine, well sorted with a minor bimodal medium fraction, contains about $1 \%$ very fine to fine dark heavy mineral grains, loose, bright orange (10YR 6/8) grading by 2 feet depth to pale orange $(10 Y R$ 8/8) $1-6$

Sand, fine to medium, subangular to subround, light orange (10YR 7/6) $6-7$

\section{Chuckatuck Formation (back barrier facies)}

Sand, very fine, silty, slightly micaceous, pale yellowish gray (10Y 7/2) grading down to pale orange (10YR 8/8) $.7-11$

Sand, fine grading down to medium, clayey, silty, dark yellowish brown $(10 Y R 4 / 2)$ mottled yellowish gray $(5 Y 7 / 2)$ $11-13$

Silt, clayey, very fine sandy, stiff, dense, dark yellowish orange (10YR 6/6) mottled yellowish gray $(5 Y 7 / 2)$ $13-16$

Base of Chuckatuck Formation (barrier facies): +44 feet elevation

Bottomed in Chuckatuck Formation (back barrier facies) 
MU-02-4: 5.02 miles west of the east quadrangle border, 4.88 miles north of the south quadrangle border, west-central $1 / 9^{\text {th }}$ of map area (latitude $36.4459^{\circ} \mathrm{N}$, longitude $77.0891^{\circ} \mathrm{W}$ ). Surface elevation 18 feet.

\section{LITHOLOGY}

DEPTH IN FEET

\section{Windsor Formation}

Sand, dominantly fine to medium, silty, dark yellowish orange

$(10 Y R 6 / 6)$, grades to $0-2$

Sand, medium to coarse, granular, silty, dark yellowish orange $(10 Y R 6 / 6)$ mottled greenish gray $(5 G Y 6 / 1)$ grading down at 4 feet depth to light olive brown $(5 \mathrm{Y} 5 / 4)$ streaked dark gray $(N 3)$ $2-7$

\section{Yorktown Formation (Zone 2)}

Sand, very fine, silty, clayey, lower half shelly, medium greenish gray $(5 G 5 / 1)$ $7-11$

\section{Eastover Formation}

Sand, fine to medium, silty, slightly clayey, sparsely shelly, oyster shells concentrated on basal contact, medium greenish gray $(5 G Y 5 / 1)$ grading rapidly to dark greenish gray $(5 G Y 4 / 1)$ $11-35$

\section{Cape Fear Formation}

Sand, fine, dense, very micaceous, moderate reddish brown $(10 R$ 4/4) mottled light yellowish gray $(5 Y 8 / 2)$ grading down to silt, clayey, fine to medium sandy, breaks into $0.5 \mathrm{~cm}$ lumps, light yellowish gray $(5 Y 8 / 2)$. $35-46$

$\begin{array}{lr}\text { Base of Windsor Formation: } & +11 \text { feet elevation } \\ \text { Base of Yorktown Formation (Zone 2): } & +7 \text { feet elevation } \\ \text { Base of Eastover Formation: } & -17 \text { feet elevation }\end{array}$

Bottomed in Cape Fear Formation 
MU-03-5: 5.02 miles west of the east quadrangle border, 4.88 miles north of the south quadrangle border, northeast $1 / 9^{\text {th }}$ of map area (latitude $36.4675^{\circ} \mathrm{N}$, longitude $77.0087^{\circ} \mathrm{W}$ ). Surface elevation 17 feet.

\section{LITHOLOGY}

DEPTH IN FEET

\section{Tabb Formation}

Sand, very fine to fine, silty, yellowish brown (10YR 5/2), grading down through light grayish orange (10YR 8/4) to dark yellowish orange $(10 Y R 6 / 6)$, grades rapidly to $0-4$

Sand, fine to coarse, subround, poorly sorted, contains about $2 \%$ very fine to fine dark heavy mineral grains, grayish orange (10YR 7.5/4). $4-7$

Sand, very fine to fine grading down to fine, silty, clayey, light yellowish brown (10YR 6/4) grading down through yellowish gray $(5 Y 7 / 2 ; 11-12$ feet) to light greenish gray $(5 G 7 / 1)$, grades rapidly to $.7-13$

Sand, medium to coarse, granular, silty, thixotropic, yellowish gray (5Y7/2), grades to $13-17$

Sand, medium to very coarse, contains abundant granules and round quartz pebbles up to $0.5 \mathrm{~cm}$ in diameter $17-18$

\section{Yorktown Formation (Zone 2)}

Sand, very fine, silty, clayey, dark yellowish orange (10YR 6/6) grading rapidly at 18.5 feet to medium greenish gray $(5 G 5 / 1)$, shelly below 20 feet $18-22$

Shell bed, dominantly oysters, silty and clayey very fine quartz sand matrix, tough drilling, medium greenish gray $(5 G 5 / 1)$ $.22-24$

\section{Eastover Formation}

Sand, fine, well sorted, silty, sparsely shelly below 26 feet depth, grayish olive (10Y 4/2), grades rapidly at base to $.24-30$

Sand, medium to coarse, contains abundant round quartz pebbles up to $0.5 \mathrm{~cm}$ in diameter, grayish olive $(10 Y 4 / 2)$ $30-31$

\section{St. Marys Formation}

Silt, very clayey, very fine sandy, sticky, greasy, medium greenish gray $(5 G Y 4 / 5 / 1)$, grades rapidly to. $31-35$ 
Sand, fine to medium, silty, clayey, contains abundant subround to round quartz pebbles up to $4 \mathrm{~cm}$ in diameter at base, medium

greenish gray $(5 G Y 4.5 / 1)$.

$35-36$

\section{Aquia Formation}

Sand, fine to medium, silty, glauconitic, contains scattered round

quartz granules, very dark greenish gray $(5 G Y 3 / 1)$ $36-44$

Sand, medium to very coarse, contains abundant round quartz pebbles

up to $3 \mathrm{~cm}$ in diameter, very dark greenish gray $(5 G Y 3 / 1)$... $.44-45$

\section{Cape Fear Formation}

Sand, fine to coarse, clayey, contains abundant round quartz granules and small pebbles up to $0.5 \mathrm{~cm}$ in diameter, greenish gray $(5 G 6 / 1)$. $45-51$

Base of Tabb Formation:

-1 foot elevation

Base of Yorktown Formation (Zone 2): $\quad-7$ feet elevation

Base of Eastover Formation:

-14 feet elevation

Base of St. Marys Formation:

-19 feet elevation

Base of Aquia Formation:

-28 feet elevation

Bottomed in Cape Fear Formation 
MU-03-6: 0.10 mile west of the east quadrangle border, 2.60 miles north of the south quadrangle border, southeast $1 / 9^{\text {th }}$ of map area (latitude $36.4132^{\circ} \mathrm{N}$, longitude $77.0013^{\circ} \mathrm{W}$ ). Surface elevation 27 feet.

\section{LITHOLOGY}

DEPTH IN FEET

\section{Shirley Formation}

Sand, very fine, silty, slightly clayey, very pale yellowish brown (10YR 7/4) grading down to dark yellowish orange (10YR 6/6)..... $0-1$

Silt, very fine sandy, clayey, finely micaceous, stiff, yellowish gray (5Y 7/2) mottled dark yellowish orange (10YR 6/6; 1-6 feet) grading down to yellowish gray $(5 Y 7 / 2)$. $1-9$

Sand, fine to very fine, silty, not clayey, soft, yellowish gray $(5 Y 7 / 2)$ $9-11$

\section{Yorktown Formation (Zone 2)}

Silt, very fine sandy, clayey, finely micaceous, dark yellowish orange $(10 Y R 6 / 6)$ $11-14$

Silt, very fine sandy, clayey, finely micaceous, yellowish gray $(5 Y 7 / 2)$ $14-15$

Silt, very fine sandy, clayey, to sand, very fine, silty and clayey, finely micaceous, medium greenish gray $(5 G Y 5 / 1)$. $15-26$

Silt, very fine sandy, clayey, to sand, very fine, silty and clayey, finely micaceous, shelly, medium greenish gray $(5 G Y 5 / 1)$ $26-28$

Silt, very fine sandy, clayey, to sand, very fine, silty and clayey, finely micaceous, medium greenish gray $(5 G Y 5 / 1)$ $.28-39$

Silt, very fine sandy, clayey, to sand, very fine, silty and clayey, finely micaceous, shelly, medium greenish gray $(5 G Y 5 / 1)$ $39-42$

Sand, medium to coarse, clayey and silty, worn shell fragments abundant, dark greenish gray $(5 G 4 / 1)$ grading rapidly down to medium greenish gray $(5 G Y 5 / 1)$ $.42-46$

\section{Eastover Formation}

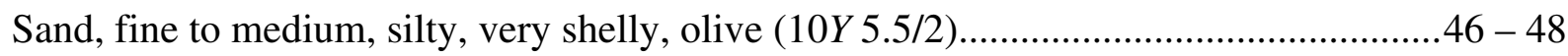

Sand, medium to coarse, dense, silty, very shelly, grayish olive $(10 Y 4 / 2)$. $.48-51$ 
Base of Shirley Formation: +16 feet elevation

Base of Yorktown Formation (Zone 2): $\quad-19$ feet elevation

Bottomed in Eastover Formation 


\section{NORFLEET QUADRANGLE}

NF-03-1: 1.92 miles west of the east quadrangle border, 5.39 miles north of the south quadrangle border, east-central $1 / 9^{\text {th }}$ of map area (latitude $36.2032^{\circ} \mathrm{N}$, longitude $77.2838^{\circ} \mathrm{W}$ ). Surface elevation 87 feet.

\section{LITHOLOGY}

DEPTH IN FEET

\section{Windsor Formation}

Sand, very fine to fine, silty and clayey, stiff, dark yellowish orange (10YR 6/6) mottled yellowish brown (10YR 5/2), dark yellowish brown (10YR 4/6), and dusky yellow (5Y 6/4) $0-8$

Sand, fine, silty, yellowish gray (5Y 7/2) mottled yellowish orange $(10 Y R$ 7/6) and dark yellowish brown (10YR 4/6) $8-11$

Sand, fine to medium with scattered coarse grains present, silty, yellowish orange (10YR 7/8) $11-17$

Sand, medium to coarse, scattered pebbles of quartz and clay to $1 \mathrm{~cm}$ diameter present, dark yellowish orange $(10 Y R$ 6/6) grading by 20 feet to moderate yellowish brown $(10 Y R 5 / 6)$ $17-23$

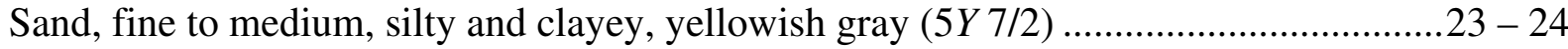

Silt, very fine sandy, clayey, dusky yellow (5Y 6/4) $.24-25$

Sand, fine to medium, silty and clayey, dark yellowish orange $(5 Y 7 / 2)$ $25-26$

Sand, fine, silty, soft, thixotropic, dark yellowish orange (10YR 6/6) $.26-31$

Silt, very fine sandy, clayey, stiff and dense, pale olive $(5 Y 6 / 2)$ $31-31.5$

Sand, fine to medium grading down to medium, silty, soft, dark yellowish orange $(10 Y R 6 / 6)$ $31.5-39$

\section{Chowan River Formation}

Sand, very fine, silty, clayey, yellowish gray ( $5 Y 7 / 2)$ streaked dark yellowish orange $(10 Y R 6 / 6)$ grading down in basal foot to medium greenish gray $(5 G 5 / 1)$ $39-43$

Sand, fine to very fine, well sorted, clean, contains tiny rip-up clay clasts, yellowish orange (10YR 7/6), grading down to sand, very fine to fine, silty, clayey, yellowish orange $(10 Y R$ 7/6) mottled dark yellowish orange $(10 Y R 6 / 6)$ and yellowish gray $(5 \mathrm{Y} 7 / 2)$ $43-51$ 
Sand, fine to medium grading down to medium to coarse, contains round quartz granules near base, yellowish orange (10YR 7/6) grading down through moderate yellowish brown $(10 Y R$ 5/6) to light olive brown $(5 Y 5 / 4$; 63-65 feet depth)......

$51-65$

\section{Yorktown Formation (Zone 2)}

Sand, very fine, silty, clayey, shelly, light reddish brown $(10 R 5 / 6)$

in top 4 inches, medium greenish gray $(5 G Y 5 / 1)$ below that. $65-70$

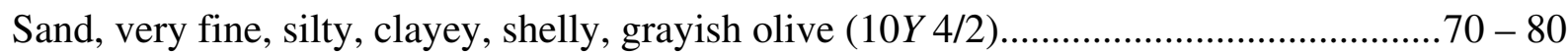

Sand, fine to medium, shelly, contains clayballs to $1 \mathrm{~cm}$ diameter of underlying lithology, grayish olive (10Y 4/2) $80-81$

\section{Cape Fear Formation}

Sand, very fine to fine, clayey and silty, micaceous, dense, stiff, pale olive gray $(5 Y 7 / 1)$ grading down to olive brown (5Y 4/4) mottled pale olive gray $(5 Y 7 / 1)$ and moderate reddish brown $(10 R 4 / 6)$ $.81-86$

Base of Windsor Formation: $\quad+48$ feet elevation

Base of Chowan River Formation: $\quad+22$ feet elevation

Base of Yorktown Formation: $\quad+6$ feet elevation

Bottomed in Cape Fear Formation 
NF-03-2: 6.20 miles west of the east quadrangle border, 3.54 miles north of the south quadrangle border, west-central $1 / 9^{\text {th }}$ of map area (latitude $36.1764^{\circ} \mathrm{N}$, longitude $77.3602^{\circ} \mathrm{W}$ ). Surface elevation 42 feet.

\section{LITHOLOGY}

DEPTH IN FEET

\section{Older Alluvium}

Sand, fine, well sorted, dark yellowish brown (10YR 4/4)

$.0-1$

Sand, fine grading down to very fine to fine, silty, slightly clayey, dark yellowish brown (10YR 4/4) grading through dark olive brown (5Y 3/4) and through dark olive gray $(5 Y 3 / 1)$ to brownish gray $(5 Y R 4 / 1)$ $1-7$

Sand, fine rapidly grading down to coarse to very coarse, contains abundant subround to round quartz pebbles up to $1 \mathrm{~cm}$ in diameter, light greenish gray $(5 G Y 7 / 1)$ $.7-11$

Sand, coarse to very coarse, sparsely pebbly, loose, yellowish brown $(10 Y R 5 / 2)$ flecked with orange $(10 Y R 6 / 8)$ $.11-21$

Sand, very fine to coarse, very poorly sorted, silty, clayey, stiff, moderate yellowish brown (10YR 5/4) mottled dark yellowish brown $(10 Y R 4 / 2)$ $.21-22$

\section{Cape Fear Formation}

Sand, very fine, contains scattered fine to medium grains, silty, clayey, stiff, dense, medium olive gray ( $5 Y 5 / 1)$ mottled reddish brown $(10 R 5 / 6)$ grading down to brownish gray $(5 Y R 4 / 1)$ mottled reddish brown $(10 R 5 / 6)$ $22-26$

Base of older alluvium: +20 feet elevation

Bottomed in Cape Fear Formation 
NF-03-3: 6.63 miles west of the east quadrangle border, 6.79 miles north of the south quadrangle border, northwest $1 / 9^{\text {th }}$ of map area (latitude $36.2234^{\circ} \mathrm{N}$, longitude $77.3680^{\circ} \mathrm{W}$ ). Surface elevation 35 feet.

\section{LITHOLOGY}

DEPTH IN FEET

\section{Alluvium}

Sand, fine, well sorted, dark brownish gray (5YR 3/1)

$.0-1$

Sand, fine grading down to fine to medium, silty, slightly micaceous, medium brown (5YR 4/6) grading down to dark yellowish brown (10YR 4/4) $1-6$

Sand, medium to coarse, contains round quartz pebbles up to $2 \mathrm{~cm}$ in diameter, dark yellowish brown (10YR 4/4). $6-9$

Sand, very fine to fine, silty, very micaceous, very dark yellowish orange $(10 Y R 4 / 6)$, grades to $9-11$

Sand, medium to coarse, contains round quartz pebbles up to $1 \mathrm{~cm}$ in diameter, dusky yellow (5Y 6/4). $11-14$

\section{Cape Fear Formation}

Silt, clayey, very fine sandy, micaceous, very dense, tough drilling, yellowish gray $(5 Y 7 / 2)$. $14-16$

Base of alluvium: +21 feet elevation

Bottomed in Cape Fear Formation 


\section{PALMYRA QUADRANGLE}

PA-02-1: 2.11 miles west of the east quadrangle border, 6.52 miles north of the south quadrangle border, northeast $1 / 9^{\text {th }}$ of map area (latitude $36.0947^{\circ} \mathrm{N}$, longitude $77.2715^{\circ} \mathrm{W}$ ). Surface elevation 27 feet.

\section{LITHOLOGY}

DEPTH IN FEET

\section{Older Alluvium}

Sand, very fine to fine, silty, clayey, micaceous, dark orange $(10 Y R 3 / 6)$, grades rapidly to $0-6$

Sand, fine to medium, contains scattered coarse grains, silty, dark grayish orange (10YR 5/6), grading down to medium to coarse, contains quartz pebbles up to $1 \mathrm{~cm}$ in diameter, yellowish orange $(10 Y R 7 / 6)$ $6-14$

\section{Cape Fear Formation}

Sand, fine, silty, clayey, much denser than above, light yellowish gray $(5 Y 8 / 2)$ grading through grayish orange (10YR 7/4) to orange $(10 Y R 4 / 6)$, grades to $14-15$

Sand, medium to coarse, silty, greenish gray $(5 G 6 / 1)$ $15-22$

Sand, very fine to fine, contains scattered medium and coarse grains, silty, clayey, dense, stiff, greenish gray (5GY 6/1) grading through greenish gray $(5 G Y 6 / 1)$ mottled dusky orange (10YR 2/6; 25-28 feet) to olive (10Y 5/2) $22-36$

Base of older alluvium: +13 feet elevation

Bottomed in Cape Fear Formation 
PA-02-2: 1.12 miles west of the east quadrangle border, 1.50 miles north of the south quadrangle border, southeast $1 / 9^{\text {th }}$ of map area (latitude $36.0218^{\circ} \mathrm{N}$, longitude $77.2699^{\circ} \mathrm{W}$ ). Surface elevation 81 feet.

\section{LITHOLOGY}

DEPTH IN FEET

\section{Windsor Formation}

Sand, dominantly fine but very fine to medium, silty, clayey, pale

yellowish brown $(10 Y R$ 6/2) grading down to grayish orange (10YR 7/4) $0-1$

Sand, very fine to coarse, poorly sorted, coarse fraction subangular, dark yellowish gray $(5 Y 6 / 2)$, grades rapidly to.... $1-7$

Sand, very fine to fine, silty, clayey, dense, tough, dark yellowish gray (5Y 6/2) streaked orange (10YR 4/6) $.7-11$

Sand, fine, well sorted, silty, soft, sharp basal contact, dark grayish orange $(10 Y R 6 / 4)$ $11-19$

Sand, very fine, silty, interbedded with silt, clayey, very fine sandy, finely micaceous, medium greenish gray $(5 G Y 5 / 1)$. $19-37$

Sand, fine, subround, silty, grading down through medium to coarse, round quartz pebbles present at base up to $3 \mathrm{~cm}$ in diameter, soft, olive $(10 Y 5 / 2)$ $.37-47$

\section{Yorktown Formation (Zone 2)}

Sand, very fine, silty, interbedded with sand, very fine to fine, silty, clayey, locally shelly (mostly Mulinia sp.), medium greenish gray $(5 G Y 5 / 1)$ $.47-75$

Shell bed with diverse fauna, silty fine sand matrix, medium greenish gray $(5 G Y 5 / 1)$ $.75-76$

\section{Cape Fear Formation}

Sand, medium to coarse, slightly silty, clayey, very dense, contains scattered small round quartz pebbles up to $1 \mathrm{~cm}$ in diameter, light olive gray $(5 Y 6 / 1)$ $.76-81$ 
PA-02-3: 6.32 miles west of the east quadrangle border, 6.54 miles north of the south quadrangle border, northwest $1 / 9^{\text {th }}$ of map area (latitude $36.0951^{\circ} \mathrm{N}$, longitude $77.3626^{\circ} \mathrm{W}$ ). Surface elevation 95 feet.

\section{LITHOLOGY}

DEPTH IN FEET

\section{Windsor Formation}

Sand, very fine to fine, silty, slightly clayey, finely micaceous, dusky yellow (5Y 6/4) grading down to dark yellowish orange (10YR 6/6) $.0-1$

Sand, very fine to fine, silty, clayey, stiff, pale olive gray $(5 Y 7 / 1)$ mottled dark orange (10YR 3/6) $1-6$

Sand, very fine to fine grading down to fine to medium, silty, clayey, coarsely micaceous, moderate orange (10YR 5/6) $6-11$

Sand, very fine to coarse, very poorly sorted, silty, clayey, moderate orange $(10 Y R 5 / 6)$ $11-19$

Silt, clayey, very fine sandy, medium greenish gray $(5 G Y 5 / 1)$ $.19-25$

Sand, very fine to fine, silty, micaceous, interbedded with silt, very fine to fine sandy, micaceous, plant fragments present at base, moderate grayish green $(10 G Y 6 / 2)$. $.25-28$

Sand, fine to medium, silty, thixotropic, moderate orange (10YR 5/6) changing at 28.5 feet to light yellowish gray $(5 Y 8 / 2)$. $.28-31$

Sand, fine to coarse, very poorly sorted, silty, contains rare subangular to subround quartz pebbles up to $2 \mathrm{~cm}$ in diameter, moderate olive gray $(5 Y 5 / 1)$, grades to $31-40$

Sand, fine, silty, olive (10Y 5/2) $40-65$

\section{Yorktown Formation (Zone 2)}

Silt, clayey, pale olive gray $(5 Y 7 / 1)$, four inches thick at 65

Sand, fine, well sorted, sparsely shelly, pale olive gray $(5 Y 7 / 1)$ $.65-79$

Sand, fine to medium, contains abundant quartz granules and pebbles up to $1 \mathrm{~cm}$ in diameter, pale olive gray $(5 Y 7 / 1)$... $.79-80$

Peat, woody, brownish black (5YR 2/1), four inches thick at 80 


\section{Cape Fear Formation}

Sand, fine to medium, angular to subangular, sparsely micaceous, dense, light olive gray $(5 Y 6 / 1)$. $.80-86$

Base of Windsor Formation: $\quad+30$ feet elevation

Base of Yorktown Formation (Zone 2): $\quad+15$ feet elevation

Bottomed in Cape Fear Formation 
PA-02-4: 6.14 miles west of the east quadrangle border, 1.83 miles north of the south quadrangle border, southwest $1 / 9^{\text {th }}$ of map area (latitude $36.0270^{\circ} \mathrm{N}$, longitude $77.3590^{\circ} \mathrm{W}$ ). Surface elevation 88 feet.

\section{LITHOLOGY}

DEPTH IN FEET

\section{Windsor Formation}

Sand, fine, silty, pale yellowish brown (10YR 6/2) grading down

to dark yellowish orange $(10 Y R 6 / 6)$, grades to..... $0-1$

Sand, fine to medium, silty, clayey, micaceous, dark yellowish orange $(10 Y R 6 / 6)$, grades to. $1-5$

Sand, fine, silty, contains about $1 \%$ very fine to fine dark heavy mineral grains, softer than above, yellowish gray $(5 Y 7 / 2)$ grading down at 8 feet to dark orange (10YR 3/6) $5-21$

Sand, fine, well sorted interbedded with sporadic layers of tough, silty and clayey very fine sand, dark greenish gray $(5 G Y 5 / 1)$, grades to $.21-33$

Sand, fine to medium, contains abundant round quartz pebbles, dark greenish gray $(5 G Y 4 / 1)$ $33-34$

\section{Yorktown Formation (Zone 2)}

Silt, very fine sandy, clayey, contains sand-filled burrows in uppermost foot, medium greenish gray $(5 G Y 5 / 1)$, grades to $.34-37$

Silt, very fine sandy, clayey, shelly with pectenid fragments and abundant Mulinia sp. (some with pearly luster), medium greenish gray $(5 G Y 5 / 1)$, grades to $.37-62$

Sand, very fine to fine, silty, medium greenish gray $(5 G Y 5 / 1)$, grades to $62-69$

Sand, fine to medium, contains abundant round quartz pebbles up to $4 \mathrm{~cm}$ in diameter and pyrite-cemented clumps of sand, medium greenish gray $(5 G Y 5 / 1)$ $69-70$

Peat, woody, brownish black (5YR 2/1), one inch thick at 70

\section{Cape Fear Formation}

Sand, dominantly fine, silty, slightly clayey, very dense, very tough, medium greenish gray $(5 G Y 5 / 1)$, grading down to sand, very fine to fine, silty, clayey, light olive gray $(5 Y 6 / 1)$ $70-76$ 
Base of Windsor Formation:

+54 feet elevation

Base of Yorktown Formation (Zone 2): $\quad+18$ feet elevation

Bottomed in Cape Fear Formation 


\section{REPUBLICAN QUADRANGLE}

RE-02-1: 2.00 miles west of the east quadrangle border, 7.09 miles north of the south quadrangle border, northeast $1 / 9^{\text {th }}$ of map area (latitude $36.1032^{\circ} \mathrm{N}$, longitude $77.0355^{\circ} \mathrm{W}$ ). Surface elevation 45 feet.

\section{LITHOLOGY}

DEPTH IN FEET

\section{Charles City Formation}

Sand, very fine to fine, silty, humic, dark yellowish brown (10YR 4/2), grades rapidly to. $0-1$

Sand, very fine to fine, silty, contains about $1 \%$ very fine to fine dark heavy mineral grains near base, dark grayish orange (10YR 6/4), grades to $1-6$

Sand, very fine to fine, silty, clayey, sticky, more dense than above, dark grayish orange $(10 Y R 6 / 4)$ mottled yellowish gray $(5 Y 7 / 2)$ $6-11$

\section{Yorktown Formation (Zone 2)}

Silt, clayey, very fine sandy, finely micaceous, medium olive gray $(5 Y 5 / 1)$ grading at around 26 feet to medium greenish gray $(5 G 5 / 1)$. $11-36$

Sand, very fine grading down to fine, silty, contains about $1 \%$ very fine to fine dark heavy mineral grains, moderate grayish green $(10 G 5 / 2)$ $.36-50$

Sand, fine, slightly silty, interbedded with sand, very fine, silty, clayey, sparsely shelly (mostly Mulinia sp.), medium greenish gray $(5 G Y 5 / 1)$ $.50-68$

Sand, fine, shelly (including pectenids and Mulinia sp.), medium greenish gray $(5 G Y 5 / 1)$ $.68-79$

Gravel, very hard drilling, no recovery. $.79-82$

\section{Jericho Run Formation}

Sand, dominantly fine to medium but with minor fraction of subround and round coarse to very coarse grains, silty, contains sparse shell fragments and fine silvery mica, dark olive gray $(5 Y 3 / 1)$... $.82-91$

Base of Charles City Formation: +34 feet elevation Base of Yorktown Formation (Zone 2): $\quad-37$ feet elevation 
RE-02-2: 0.68 mile west of the east quadrangle border, 7.08 miles north of the south quadrangle border, northeast $1 / 9^{\text {th }}$ of map area (latitude $36.1029^{\circ} \mathrm{N}$, longitude $77.0121^{\circ} \mathrm{W}$ ). Surface elevation 68 feet.

\section{LITHOLOGY}

DEPTH IN FEET

\section{Charles City Formation}

Sand, fine, silty, slightly clayey, dark yellowish brown (10YR 4/2)

mottled pale yellowish brown (10YR 6/4) grading through dark

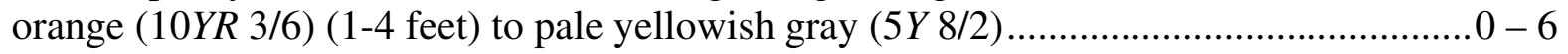

Sand, very fine to fine, silty, clayey, dark orange (10YR 3/6)

mottled pale yellowish gray $(5 Y 8 / 2)$, grades rapidly to

$6-26$

Sand, fine to medium, silty, soft, pale yellowish gray $(5 Y 8 / 2)$ sparsely mottled dark orange (10YR 3/6) grading down about 26 feet to moderate yellowish orange (10YR 7/6)

Sand, fine to medium coarsening downward to coarse to very coarse, contains sparse subround quartz pebbles up to $1 \mathrm{~cm}$ in diameter, light olive gray $(5 Y 6 / 1)$ $29-36$

\section{Yorktown Formation (Zone 2)}

Sand, fine, slightly micaceous, shelly in basal foot, moderate greenish gray $(5 G 7 / 1)$ grading down by 38 feet to dark olive gray $(5 Y 3 / 1)$ $.36-41$

Base of Charles City Formation: +32 feet elevation

Bottomed in Yorktown Formation (Zone 2) 
RE-02-3: 1.56 miles west of the east quadrangle border, 1.08 miles north of the south quadrangle border, southeast $1 / 9^{\text {th }}$ of map area (latitude $36.0155^{\circ} \mathrm{N}$, longitude $77.0273^{\circ} \mathrm{W}$ ). Surface elevation 38 feet.

\section{LITHOLOGY}

DEPTH IN FEET

\section{Chuckatuck Formation}

Sand, very fine to fine grading down to fine to medium, silty, clayey, micaceous, very pale yellowish brown $(10 Y R 7 / 2)$ grading down at one foot to dark yellowish orange (10YR 6/6), grades rapidly to $0-5$

Sand, fine to coarse, poorly sorted, silty, loose, pale grayish orange (10YR 8/4), grades to. $.5-6$

Sand, fine to medium, silty, contains sparse very fine to fine dark heavy mineral grains, medium grayish orange (10YR 7/6) grading down to pale yellowish gray $(5 Y 8 / 2)$ $6-11$

Sand, fine to medium grading through medium to coarse to coarse to very coarse, contains abundant subround to round quartz pebbles up to $1 \mathrm{~cm}$ in diameter near base, pale yellowish gray $(5 Y 8 / 2)$ grading down to moderate greenish gray $(5 G Y 7 / 1)$ $11-27$

\section{Yorktown Formation (Zone 2)}

Sand, very fine, silty, clayey, interbedded with silt, clayey, very fine sandy, finely micaceous, sparse shell fragments scattered throughout, dark greenish gray $(5 G 4 / 1)$ $27-82$

Gravel, round quartz granules and pebbles up to $1 \mathrm{~cm}$ in diameter, fine to medium sand matrix, dark greenish gray $(5 G 4 / 1)$ $.82-85$

\section{Jericho Run Formation}

Sand, fine to coarse, subround, poorly sorted, silty, contains abundant glauconite and phosphate, dark greenish gray (5GY 4/1) grading down to dusky greenish gray $(5 G Y 3 / 1)$ $85-101$ 
RE-02-4: 0.23 mile west of the east quadrangle border, 2.57 miles north of the south quadrangle border, southeast $1 / 9^{\text {th }}$ of map area (latitude $36.0369^{\circ} \mathrm{N}$, longitude $77.0042^{\circ} \mathrm{W}$ ). Surface elevation 59 feet.

\section{LITHOLOGY}

DEPTH IN FEET

\section{Charles City Formation}

Sand, fine to medium, silty, dark yellowish brown (10YR 4/2) grading down to grayish orange (10YR 7/4) $0-1$

Sand, fine to medium, silty, dark yellowish orange (10YR 6/6) grading down to pale grayish orange $(10 Y R$ 8/4). $1-6$

Sand, fine grading down to very fine, silty, clayey, micaceous, pale olive gray (5Y 7/1) mottled moderate reddish brown (10YR 4/6). $6-11$

Sand, very fine to fine, silty, clayey, dark yellowish orange (10YR 6/6) $11-16$

Sand, fine to coarse, poorly sorted, silty, thixotropic, grayish orange (10YR 7/4) $16-29$

Sand, medium to coarse, contains abundant subround to round quartz pebbles up to $2 \mathrm{~cm}$ in diameter, grayish orange (10YR 7/4) $29-30$

\section{Yorktown Formation (Zone 2)}

Sand, very fine, silty, clayey, pale yellowish gray (5Y 8/2) grading down to dark yellowish orange $(10 Y R 6 / 6)$..... $30-33$

Sand, very fine to fine, silty, slightly clayey, shell fragments present below 41 feet, very dark greenish gray $(5 G 3 / 1)$ $33-46$

Base of Charles City Formation: +29 feet elevation

Bottomed in Yorktown Formation (Zone 2) 
RE-02-5: 6.19 miles west of the east quadrangle border, 6.76 miles north of the south quadrangle border, northwest $1 / 9^{\text {th }}$ of map area (latitude $36.0979^{\circ} \mathrm{N}$, longitude $77.1082^{\circ} \mathrm{W}$ ). Surface elevation 54 feet.

\section{LITHOLOGY}

DEPTH IN FEET

\section{Charles City Formation}

Sand, very fine to fine, silty, clayey, stiff, dark grayish orange $(10 Y R$ 6/4) ..................... 0 - 1

Silt, clayey, very fine sandy, micaceous, pale yellowish gray $(5 Y 8 / 2)$

mottled moderate reddish brown $(10 R 4 / 6)$, grades rapidly to $1-7$

Sand, fine, silty, well sorted, thixotropic, light olive gray $(5 Y 5 / 2)$ grading down to pale grayish orange $(10 Y R$ 8/4). $.7-11$

Sand, fine to medium grading down to medium to coarse, silty, dark grayish orange $(10 Y R$ 6/4) $11-19$

\section{Yorktown Formation (Zone 2)}

Sand, very fine, silty, clayey, finely micaceous, dusky greenish gray $(5 G 3 / 1) \ldots \ldots \ldots \ldots . . .19-22$

Sand, very fine to fine, silty, contains sparse shell fragments, medium greenish gray $(5 G Y 5 / 1)$ $22-39$

Shell bed, silty fine sand matrix, medium greenish gray $(5 G Y 5 / 1) \ldots$ $39-40$

Sand, very fine to fine, silty, clayey, sparsely shelly, medium greenish gray $(5 G Y 5 / 1)$ $40-81$

Sand, fine to medium, silty, clayey, sparsely shelly, medium greenish gray $(5 G Y 5 / 1)$ $.81-84$

\section{Cape Fear Formation?}

Refusal on impenetrable hard bed, wisps of pale brown $(5 Y R 5 / 2)$ to dark yellowish orange (10YR 6/6) clayey medium to very coarse sand came up on end of drill stem

Base of Charles City Formation: +35 feet elevation

Base of Yorktown Formation (Zone 2): $\quad-30$ feet elevation

Bottomed on Cape Fear Formation? 
RE-02-6: 5.93 miles west of the east quadrangle border, 0.35 mile north of the south quadrangle border, southwest $1 / 9^{\text {th }}$ of map area (latitude $36.0051^{\circ} \mathrm{N}$, longitude $77.1052^{\circ} \mathrm{W}$ ). Surface elevation 43 feet.

\section{LITHOLOGY}

DEPTH IN FEET

\section{Chuckatuck Formation}

Sand, very fine to fine, silty, moderate yellowish brown (10YR 5/4)

grading down to moderate yellowish brown $(10 Y R 5 / 2)$ $0-1$

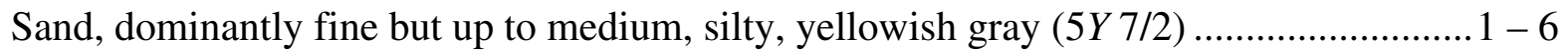

Sand, medium to coarse, subangular, silty, thixotropic, yellowish gray (5Y 7/2) grading down to dark yellowish orange (10YR 6/6) in basal foot $6-26$

\section{Charles City Formation}

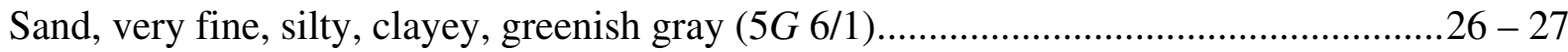

Sand, dominantly fine but up to medium grading down to dominantly medium but fine to coarse, carbon grains abundant, moderate greenish gray $(5 G Y 7 / 1)$ $27-36$

Sand, medium to coarse grading down to coarse to very coarse, scattered quartz pebbles up to $1 \mathrm{~cm}$ in diameter near base, white grains (kaolin? or gibbsite?) abundant, moderate greenish gray (5GY 7/1) $.36-59$

\section{Yorktown Formation (Zone 2)}

Sand, very fine, silty, clayey, finely micaceous, dark greenish gray (5GY 4/1), basal foot contains abundant subround to round quartz pebbles up to $2 \mathrm{~cm}$ in diameter $9-69$

\section{Jericho Run Formation}

Sand, fine, includes scattered medium and coarse grains, silty, slightly clayey, slightly micaceous, dark greenish gray $(5 G Y 3 / 1)$.... $69-81$
Base of Chuckatuck Formation:
+17 feet elevation
Base of Charles City Formation:
-16 feet elevation
Base of Yorktown Formation (Zone 2): $\quad-26$ feet elevation

Bottomed in Jericho Run Formation 


\section{RICH SQUARE QUADRANGLE}

RS-02-1: 6.46 miles west of the east quadrangle border, 7.55 miles north of the south quadrangle border, northwest $1 / 9^{\text {th }}$ of map area (latitude $36.3595^{\circ} \mathrm{N}$, longitude $77.3650^{\circ} \mathrm{W}$ ). Surface elevation 88 feet.

\section{LITHOLOGY}

DEPTH IN FEET

\section{Windsor Formation}

Silt, clayey, very fine sandy, dense, dark yellowish orange (10YR 6/6)

mottled pale olive gray $(5 Y 6 / 2)$......

$0-1$

Silt, clayey, dense, dark yellowish orange (10YR 6/6) grading down

to light yellowish gray $(5 Y 8 / 2)$, grades to

$1-9$

Sand, fine, well sorted, silty, slightly micaceous, yellowish orange

(10YR 7/6), grades to.

$9-13$

Sand, fine grading down to fine to medium, silty, loose, thixotropic, dark yellowish orange $(10 Y R$ 6/6).... $13-21$

Sand, fine to coarse, silty, contains scattered round quartz granules

and pebbles up to $1 \mathrm{~cm}$ in diameter, pale yellowish brown (10YR 6/4)

grading down by 29 feet to pale grayish orange (10YR 8/4). $21-38$

Gravel, subround quartz pebbles up to $2 \mathrm{~cm}$ in diameter, coarse to very coarse sand matrix, pale grayish orange $(10 Y R$ 8/4) $38-39$

\section{Chowan River Formation}

Silt, clayey, finely micaceous, medium greenish gray $(5 G Y 5 / 1)$

mottled moderate olive brown $(5 Y 4 / 6)$ and greenish gray $(5 G 6 / 1)$ $39-41$

Silt, clayey, finely, micaceous, medium greenish gray $(5 G 5 / 1)$ $41-42$

Sand, very fine to fine, silty, medium greenish gray $(5 G 5 / 1)$ $42-56$

Sand, medium to coarse, clean, interbedded with lenses of gravel, subround to round quartz pebbles up to $2 \mathrm{~cm}$ in diameter, dark grayish yellow $(5 Y 7 / 4)$ $.56-99$

\section{Clubhouse Formation}

Clay, silty, finely micaceous, very dense, light olive gray $(5 Y 5 / 2)$

streaked dark yellowish orange $(10 Y R$ 6/6) $99-100$

Refusal, hit impenetrable hard bed at 100 
Base of Windsor Formation: +49 feet elevation

Base of Chowan River Formation: $\quad-11$ feet elevation

Bottomed in Clubhouse Formation 
RS-02-2: 1.65 miles west of the east quadrangle border, 7.54 miles north of the south quadrangle border, northeast $1 / 9^{\text {th }}$ of map area (latitude $36.3594^{\circ} \mathrm{N}$, longitude $77.2796^{\circ} \mathrm{W}$ ). Surface elevation 83 feet.

\section{LITHOLOGY}

DEPTH IN FEET

\section{Windsor Formation}

Sand, very fine, silty, slightly clayey, dark yellowish gray $(5 Y 6 / 2)$

mottled dark yellowish orange (10YR 6/6), grades to $0-1$

Sand, very fine to fine, silty, clayey, pale olive gray $(5 Y 7 / 1)$, grades to $1-6$

Silt, clayey, very fine sandy, micaceous, pale olive gray $(5 Y 7 / 1)$ mottled moderate orange $(10 Y R 5 / 6)$, grades rapidly to $6-12$

Sand, dominantly fine with a minor medium fraction, medium fraction subangular to subround, silty, soft, moderate grayish orange $(10 Y R$ 8/4) $12-17$

Silt, clayey, stiff, medium greenish gray $(5 G 5 / 1)$, about 1 inch thick at 17

Sand, dominantly fine with a minor medium fraction, medium fraction subangular to subround, silty, soft, moderate grayish orange (10YR 8/4) $17-21$

Silt, clayey, denser than sand above, finely micaceous, light olive gray $(5 Y 6 / 1)$ grading around 25 feet to medium greenish gray $(5 G 5 / 1)$, grades to $.21-31$

Sand, very fine, silty, clayey, micaceous, medium greenish gray $(5 G 5 / 1)$ grading down to light olive gray $(5 Y 5 / 2)$ $31-41$

Silt, clayey, very fine sandy, dense, sticky, light olive gray (5Y 5/2), grades to $.41-52$

Sand, fine, well sorted, silty, soft, contains $2-5 \%$ very fine to fine dark heavy mineral grains, light olive gray $(5 Y 5 / 2)$ $.52-57$

Gravel, subround to round quartz pebbles up to $3 \mathrm{~cm}$ in diameter..... $.57-61$

\section{Yorktown Formation (Zone 2)?}

Silty clay wisps in basal gravel, dark yellowish orange $(10 Y R 6 / 6)$ at 61

Base of Windsor Formation: +22 feet elevation

Bottomed on Yorktown Formation (Zone 2)? 
RS-03-3: 4.91 miles west of the east quadrangle border, 0.57 mile north of the south quadrangle border, southwest $1 / 9^{\text {th }}$ of map area (latitude $36.2583^{\circ} \mathrm{N}$, longitude $77.3375^{\circ} \mathrm{W}$ ). Surface elevation 60 feet.

\section{LITHOLOGY}

DEPTH IN FEET

\section{Charles City Formation}

Silt, very fine sandy, clayey, stiff, dusky yellow (5Y 6/4) mottled dark yellowish brown $(10 Y R 4 / 6)$ $0-1$

Sand, very fine, silty, clayey, stiff, dusky yellow (5Y 6/4) mottled dark yellowish brown $(10 Y R$ 4/6) $1-2$

Sand, fine, well sorted, silty, grayish orange (10YR 7/4) grading down to light yellowish gray $(5 Y 8 / 2)$ $2-6$

Sand, fine to medium, grayish orange (10YR 7/4), grades to $6-10$

Sand, medium to coarse, contains abundant subround to round quartz pebbles increasing downward in diameter from $1 \mathrm{~cm}$ at top to $2 \mathrm{~cm}$ near base, grayish orange (10YR 7/4) grading to light yellowish gray $(5 Y 8 / 2)$ $10-25$

Sand, coarse to very coarse, contains abundant subround to round quartz pebbles up to $4 \mathrm{~cm}$ in diameter, dark yellowish brown (10YR 6/4) grading down to olive brown (5Y 3/4) $25-30$

\section{Yorktown Formation (Zone 2)}

Sand, very fine to fine grading down to fine to medium, quartz pebbles up to $3 \mathrm{~cm}$ in diameter on basal contact, silty, sparsely shelly, medium greenish gray $(5 G Y 5 / 1)$ $30-38$

\section{Cape Fear Formation}

Sand, very fine to fine, silty, clayey, dense, light greenish gray (5GY 7/1), grades rapidly to. $38-41$

Sand, fine to medium, silty, clayey, dense, moderate reddish brown $(10 R 4 / 6)$ mottled dark yellowish gray $(5 Y 6 / 2)$, grades rapidly to $.41-44$

Sand, medium to coarse, dark yellowish gray (5Y 6/2), grades to $44-45$

Sand, fine to medium, silty, clayey, dense, moderate reddish brown $(10 R 4 / 6)$ $45-46$ 
Base of Charles City Formation: $\quad+30$ feet elevation

Base of Yorktown Formation (Zone 2): $\quad+22$ feet elevation

Bottomed in Cape Fear Formation 
RS-03-4: 0.99 mile west of the east quadrangle border, 1.33 miles north of the south quadrangle border, southeast $1 / 9^{\text {th }}$ of map area (latitude $36.2695^{\circ} \mathrm{N}$, longitude $77.2675^{\circ} \mathrm{W}$ ). Surface elevation 73 feet.

\section{LITHOLOGY}

DEPTH IN FEET

\section{Charles City Formation}

Silt, very fine sandy, clayey, finely micaceous, stiff, pale brown (10YR 6/2) grading down to pale olive (10Y 6/2) mottled dark yellowish orange $(10 Y R 6 / 6)$ $0-1$

Silt, very fine sandy, clayey, finely micaceous, stiff, dark yellowish brown $(10 Y R$ 4/6) mottled yellowish gray $(5 Y 7 / 2)$ grading rapidly through yellowish orange $(10 Y R 7 / 6)$ mottled yellowish gray $(5 Y 7 / 2 ; 2-2.5$ feet) to yellowish gray $(5 Y 7 / 2)$ mottled yellowish orange $(10 Y R 7 / 6)$ and moderate grayish brown $(5 Y R 4 / 2)$ $1-6$

Sand, very fine to fine with scattered medium grains, silty, clayey, micaceous, dark yellowish orange mottled light greenish gray (5GY 7/1) grading through light greenish gray (5GY 7/1) mottled dark yellowish orange $(10 Y R$ 7/6) (11-20 feet) to light olive gray $(5 Y 5 / 2) \ldots \ldots \ldots \ldots \ldots \ldots \ldots . . .6-23$

Sand, fine grading down to fine to medium, silty, micaceous, loose, thixotropic, dusky yellow (5Y 6/4), grades to . $23-28$

Sand, medium to coarse, silty, loose, light yellowish gray $(5 Y 8 / 2)$ grading at 29 feet to pale olive gray $(5 Y 7 / 1)$. $.28-45$

Sand, coarse to very coarse, loose, silty, contains quartz granules and pebbles up to $1 \mathrm{~cm}$ in diameter, pale olive gray $(5 Y 7 / 1)$ $45-50$

Sand, very fine, clayey, silty, medium greenish gray $(5 G 5 / 1)$ $.50-51$

Sand, medium to very coarse, loose, silty, contains abundant quartz granules and pebbles up to $1 \mathrm{~cm}$ in diameter, pale olive gray $(5 Y 7 / 1)$ $.51-59$

Sand, fine to medium, contains sparse quartz granules and pebbles up to $0.5 \mathrm{~cm}$ in diameter, light greenish gray $(5 G Y 7 / 1)$. $.59-62$

Sand, medium to coarse, contains very abundant subround to round quartz granules and pebbles up to $1 \mathrm{~cm}$ in diameter, light greenish gray $(5 G Y 7 / 1)$ $.62-65$

\section{Yorktown Formation (Zone 2)}

Sand, very fine, clayey, silty, micaceous, dense, sticky, dark greenish gray $(5 G Y 4 / 1)$ $65-71$ 
Base of Charles City Formation: +8 feet elevation

Bottomed in Yorktown Formation (Zone 2) 
RS-03-5: 2.25 miles west of the east quadrangle border, 5.04 miles north of the south quadrangle border, east-central $1 / 9^{\text {th }}$ of map area (latitude $36.3231^{\circ} \mathrm{N}$, longitude $77.2899^{\circ} \mathrm{W}$ ). Surface elevation 69 feet.

\section{LITHOLOGY}

DEPTH IN FEET

\section{Charles City Formation}

Sand, very fine to fine, silty, clayey, sticky, pale yellowish brown $(10 Y R 6 / 2)$ grading very rapidly to yellowish orange $(10 Y R 7 / 6)$ $0-1$

Sand, very fine grading down to very fine to fine, silty, clayey, yellowish orange $(10 Y R$ 7/6) grading through light yellowish gray (5Y 8/2) mottled yellowish orange (10YR 7/6; 2-4 feet) to moderate yellowish brown $(10 Y R$ 5/6) $1-6$

Sand, very fine to fine, silty, clayey, micaceous, yellowish gray (5Y 7/2) mottled moderate yellowish brown (10YR 5/6) and yellowish orange $(10 Y R 7 / 6)$ $6-10$

Sand, very fine to fine, clean, dusky yellow (5Y 6/4) $10-12$

Sand, fine to medium grading down to medium to coarse, subangular, silty, soft, thixotropic, yellowish brown (10YR 5/2) grading rapidly down to dark yellowish brown (10YR 4/4) $12-20$

Silt, clayey, very fine sandy, yellowish gray $(5 Y 7 / 2)$ $.20-21$

Sand, very fine to fine grading down to fine to medium, silty, slightly micaceous, yellowish gray $(5 Y 7 / 2)$, grades to $21-25$

Sand, medium to coarse grading down to coarse to very coarse, gravelly with round quartz clasts ranging up to $4 \mathrm{~cm}$ in diameter near top and increasing to $6 \mathrm{~cm}$ in diameter toward base, yellowish gray $(5 Y 7 / 2)$ $.25-41$

\section{Yorktown Formation (Zone 2)}

Sand, very fine to fine, silty, clayey, medium greenish gray $(5 G Y 5 / 1)$ grading down to dark greenish gray $(5 G Y 4 / 1)$ $41-51$

Sand, fine to medium grading down to medium to coarse, dark greenish gray $(5 G Y 4 / 1)$ $.51-63$

\section{Cape Fear Formation}

Sand, fine to medium, very micaceous, silty, clayey, much denser than above, greenish gray $(5 G 6 / 1)$ grading down to light greenish gray $(5 G 7 / 1)$ $.63-66$ 
Base of Charles City Formation:

Base of Yorktown Formation (Zone 2): $\quad+6$ feet elevation

Bottomed in Cape Fear Formation
+28 feet elevation 


\section{RINGWOOD OUADRANGLE}

RI-03-1: 1.03 miles west of the east quadrangle border, 3.64 miles north of the south quadrangle border, east-central $1 / 9^{\text {th }}$ of map area (latitude $36.1780^{\circ} \mathrm{N}$, longitude $77.7689^{\circ} \mathrm{W}$ ). Surface elevation 122 feet.

\section{LITHOLOGY}

DEPTH IN FEET

\section{Upper Bacons Castle Formation, Bahramsville Member}

Sand, fine to coarse, poorly sorted, silty, slightly clayey, dark grayish orange $(10 Y R 6 / 4)$ $0-7$

Sand, dominantly medium, fine to coarse, silty, contains about $1 \%$ very fine to fine dark heavy mineral grains, yellowish gray $(5 Y 7 / 1)$. $.7-11$

Silt, clayey, very fine sandy, stiff, dense, yellowish gray $(5 Y 7 / 1)$ $11-15$

Sand, loose, fine with scattered subround to round medium and coarse grains, silty, thixotropic, dark yellowish orange $(10 Y R 6 / 6)$ $15-19$

\section{Yorktown Formation (Zone 2)}

Silt, clayey, very fine sandy, shelly below 21 feet, top six inches dark yellowish brown (10YR 4/4) and then rapidly grades to medium greenish gray $(5 G 5 / 1)$ $19-25$

Sand, very fine to fine, contains shell fragments and sparse quartz pebbles up to $2 \mathrm{~cm}$ in diameter, medium greenish gray $(5 G 5 / 1)$.... $25-25.5$

\section{Eastern Carolina Slate Belt Rocks}

Saprolite, derived from banded granite gneiss, contains angular medium quartz grains and abundant kaolinite feldspar ghosts, light greenish gray $(5 G 7 / 1)$ $25.5-26$

\footnotetext{
Base of Upper Bacons Castle Formation (Bahramsville Member): $\quad+103$ feet elevation Base of Yorktown Formation (Zone 2): +96 feet elevation
}

Bottomed in Eastern Carolina Slate Belt saprolite 
RI-03-2: 2.67 miles west of the east quadrangle border, 3.09 miles north of the south quadrangle border, central $1 / 9^{\text {th }}$ of map area (latitude $36.1699^{\circ} \mathrm{N}$, longitude $77.7972^{\circ} \mathrm{W}$ ). Surface elevation 162 feet.

\section{LITHOLOGY}

DEPTH IN FEET

\section{Lower Bacons Castle Formation, Varina Grove Member}

Sand, fine to medium, silty, very clayey, massive, dark yellowish

orange $(10 Y R 6 / 6)$ intermingled with dark reddish brown $(10 R 5 / 6)$ $0-1$

Sand, medium to coarse, subround, silty, dense, yellowish gray (5Y 7/2) mottled dark yellowish orange (10YR 6/6) and dark reddish brown $(10 R 5 / 6)$.... $1-6$

Sand, medium to coarse, subround, silty, dense, contains subangular to subround quartz pebbles up to $1 \mathrm{~cm}$ in diameter, yellowish orange $(10 Y R 7 / 6)$ $6-11$

Silt, very clayey, very fine sandy, dense, stiff, moderate reddish brown $(10 R 4 / 6)$ streaked dark yellowish orange (10YR 6/6) and yellowish gray $(5 Y 7 / 2)$ grading through pale olive gray $(5 Y 6 / 2)$ and medium brownish gray $(5 Y R 5 / 1)$, grades to. $11-20$

Silt, very clayey, very fine sandy, dense, stiff, yellowish gray (5Y 7/2) grading in basal foot to light olive brown (5Y 5/4), sparse $1 \mathrm{~cm}$ long quartz discoids along basal contact. $.20-24$

\section{Eastern Carolina Slate Belt Rocks}

Saprolite, probably from biotite gneiss, foliation locally obvious, medium dark gray $(N 4)$ blotched light olive brown (5Y 5/4). $.24-31$

Base of Lower Bacons Castle Formation (Varina Grove Member): +138 feet elevation

Bottomed in Eastern Carolina Slate Belt saprolite 


\section{ROANOKE RAPIDS OUADRANGLE}

RR-03-1: 3.82 miles west of the east quadrangle border, 4.00 miles north of the south quadrangle border, central $1 / 9^{\text {th }}$ of map area (latitude $36.4330^{\circ} \mathrm{N}$, longitude $77.6949^{\circ} \mathrm{W}$ ). Surface elevation 200 feet.

\section{LITHOLOGY}

DEPTH IN FEET

\section{Chowan River Formation}

Sand, fine to medium with minor round coarse to very coarse grains, silty, dark grayish orange (10YR 6/4) grading through pale orange $(10 Y R 7 / 2)$ to dark yellowish brown $(10 Y R 4 / 2)$, grades to $0-1$

Sand, fine to medium with minor round coarse to very coarse grains, contains round quartz pebbles up to $2 \mathrm{~cm}$ in diameter, silty, dark yellowish orange (10YR 6/6) grading down to reddish brown $(10 R 5 / 6)$, grades to $1-6$

Sand, fine to medium with minor round coarse to very coarse grains, contains abundant round quartz pebbles up to $5 \mathrm{~cm}$ in diameter, reddish brown $(10 R 5 / 6)$ mottled yellowish orange $(10 Y R 7 / 6)$ $6-10$

Sand, medium to coarse, better sorted than above, reddish brown $(10 R 5 / 6)$ grading down to yellowish orange (10YR 7/6) $10-19$

\section{Eastern Carolina Slate Belt Rocks}

Saprolite, silt, clayey, micaceous, contains scattered angular quartz grains, fragments of quartz veins present at 28-30 feet, reddish brown $(10 R 5 / 6)$, grades to $19-30$

Saprolite, crystalline fabric visible as quartz/kaolin/clay bleb pattern, moderate olive brown $(5 Y$ 4/4) streaked grayish black $(N 2)$ and dark grayish orange (10YR 6/4) $30-31$

Base of Chowan River Formation: +181 feet elevation

Bottomed in Eastern Carolina Slate Belt saprolite 
RR-03-2: 2.03 miles west of the east quadrangle border, 3.31 miles north of the south quadrangle border, east-central $1 / 9^{\text {th }}$ of map area (latitude $36.4229^{\circ} \mathrm{N}$, longitude $77.6609^{\circ} \mathrm{W}$ ). Surface elevation 137 feet.

\section{LITHOLOGY}

DEPTH IN FEET

Road fill $.0-1$

\section{Lower Bacons Castle Formation, Varina Grove Member}

Sand, very fine grading down to very fine to fine, silty, clayey, dark yellowish brown $(10 Y R$ 4/2) grading down at 0.5 foot to light olive gray $(5 Y 6 / 1)$ mottled moderate olive brown $(5 Y 4 / 4)$ $1-6$

Sand, very fine to fine, silty, clayey, light greenish gray $(5 G 7 / 1)$ grading through dark yellowish orange (10YR 6/6; 7-9 feet) to moderate yellowish gray $(5 Y 7 / 1)$ $6-11$

Sand, fine grading down to fine to medium, silty, soft, dark grayish orange (10YR 6/4) $11-19$

\section{Chowan River Formation}

Silt, very fine sandy, clayey, interbedded with silty very fine sand, clayey, finely micaceous, pale yellowish brown (10YR 6/2) $.19-20$

Silt, very fine sandy, clayey, interbedded with silty very fine sand, clayey, finely micaceous, medium greenish gray $(5 G 5 / 1)$ $20-22$

Sand, very fine to fine, silty, contains about $1-2 \%$ very fine to fine dark heavy mineral grains, micaceous, pale olive gray $(5 Y 6 / 2)$ mottled dark orange (10YR 6/8) $22-28$

Sand, coarse to very coarse, contains round quartz pebbles up to $5 \mathrm{~cm}$ in diameter, pale grayish orange (10YR 8/4) grading down to very pale orange $(10 Y R 8 / 2)$, artesian flow observed $.28-31$

Gravel, round quartz pebbles up to $5 \mathrm{~cm}$ in diameter, coarse to very coarse sand matrix, light olive brown (10Y5/4), tough drilling $.31-34$

\section{Eastern Carolina Slate Belt Rocks}

Saprolite, silt and clay, moderate olive brown (5Y 4/6) grading down at 35 feet to dark olive brown ( $5 Y 3 / 4)$, grades to $.34-37$

Saprolite, granite gneiss pattern of coarse to very coarse angular quartz, kaolin feldspar ghosts, and mica, medium greenish gray (5GY 5/1) $.37-41$ 
Base of Lower Bacons Castle Formation (Varina Grove Member): $\quad+118$ feet elevation Base of Chowan River Formation: +103 feet elevation

Bottomed in Eastern Carolina Slate Belt saprolite 
RR-03-3: 0.88 mile west of the east quadrangle border, 2.05 miles north of the south quadrangle border, southeast $1 / 9^{\text {th }}$ of map area (latitude $36.4046^{\circ} \mathrm{N}$, longitude $77.6407^{\circ} \mathrm{W}$ ). Surface elevation 147 feet.

\section{LITHOLOGY}

DEPTH IN FEET

\section{Lower Bacons Castle Formation, Varina Grove Member}

Sand, fine to coarse, subround, silty, yellowish brown (10YR 5/2)

grading down to grayish orange (10YR 7/4) $.0-1$

Sand, fine to coarse, subround, silty, dark yellowish orange (10YR 6/6) grading down to reddish brown (10R 5/6) $1-6$

Sand, medium to coarse, subround, silty, reddish brown $(10 R 5 / 6)$. $6-31$

Silt, yellowish gray $(5 Y 7 / 2)$ $31-31.5$

Sand, fine to medium, contains scattered grains of coarse sand and quartz pebbles up to $3 \mathrm{~cm}$ in diameter, silty, yellowish gray $(5 Y 7 / 2)$. $31.5-46$

Gravel, quartz pebbles up to $3 \mathrm{~cm}$ in diameter, medium to coarse sand matrix, yellowish gray $(5 Y 7 / 2)$ $.46-51$

\section{Eastern Carolina Slate Belt Rocks}

Saprolite, stringer of clayey silt with angular quartz grains on end of drill stem, medium brown (5YR 4/4) intermingled with dark yellowish orange $(10 Y R 6 / 6)$ at 51

Base of Lower Bacons Castle Formation (Varina Grove Member): +96 feet elevation Bottomed in Eastern Carolina Slate Belt saprolite 


\section{SCOTLAND NECK OUADRANGLE}

SC-03-1: 3.43 miles west of the east quadrangle border, 4.29 miles north of the south quadrangle border, central $1 / 9^{\text {th }}$ of map area (latitude $36.1874^{\circ} \mathrm{N}$, longitude $77.4360^{\circ} \mathrm{W}$ ). Surface elevation 109 feet.

\section{LITHOLOGY}

DEPTH IN FEET

\section{Upper Bacons Castle Formation, Bahramsville Member}

Sand, very fine to fine, silty, yellowish gray $(5 Y 7 / 2)$.............................................. 0 - 1

Silt, very fine sandy, clayey, yellowish gray $(5 Y 7 / 2)$ mottled dark yellowish orange (10YR 6/6) $1-7$

Sand, very fine grading down to fine, well sorted, silty, dark yellowish orange $(10 Y R 6 / 8)$ $7-11$

Sand, very fine to coarse, very poorly sorted, silty, clayey, contains scattered subangular to subround quartz granules, dark grayish orange (10YR 6/4), grades to $.11-19$

Sand, medium to coarse, silty, contains scattered subangular to subround quartz granules, dark grayish orange (10YR 6/4) grading through moderate yellowish brown (10YR 5/4; 24-27 feet) to light grayish orange $(10 Y R 8 / 6)$ $19-30$

Sand, coarse to very coarse, clean, contains round quartz granules and pebbles up to $1 \mathrm{~cm}$ in diameter at top and increasing in size up to $3 \mathrm{~cm}$ by base, pale grayish orange (10YR 9/4) grading down to light grayish orange (10YR 8/4) $30-40$

\section{Yorktown Formation (Zone 2)}

Sand, very fine, silty, clayey, stiffer than above, three inchthick cap of yellowish gray (5Y7/2) streaked dark yellowish orange $(10 Y R 6 / 6)$ overlies medium greenish gray $(5 G Y 5 / 1)$, grades to $40-51$

Sand, very fine grading through fine down to fine to medium, silty, clayey in some intervals, shelly, medium greenish gray $(5 G Y 5 / 1)$ $.51-76$

Sand, very fine, clayey and silty, denser and stiffer than above, contains scattered medium and coarse grains, round quartz and phosphate pebbles up to $2 \mathrm{~cm}$ in diameter abundant at base, medium greenish gray $(5 G 5 / 1)$ $.76-77$ 


\section{Cape Fear Formation}

Sand, very fine to coarse, modally fine, very poorly sorted, silty, slightly clayey, very dense, tough, contains subround to round granule-size clayballs, pale brownish gray $(5 Y R$ 7/1) mottled

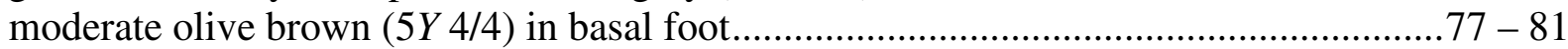

Base of Upper Bacons Castle Formation (Bahramsville Member): +69 feet elevation Base of Yorktown Formation (Zone 2): +32 feet elevation

Bottomed in Cape Fear Formation 
SC-03-2: 4.27 miles west of the east quadrangle border, 4.59 miles north of the south quadrangle border, central $1 / 9^{\text {th }}$ of map area (latitude $36.1915^{\circ} \mathrm{N}$, longitude $77.4511^{\circ} \mathrm{W}$ ). Surface elevation 134 feet.

\section{LITHOLOGY}

\section{Upper Bacons Castle Formation, Moorings Member}

Sand, fine, well sorted, yellowish brown (10YR 5/2) grading down

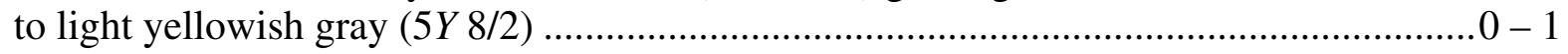

Sand, fine, well sorted, silty, dark yellowish orange $(10 Y R$ 6/6) .................................. 1 - 9

\section{Upper Bacons Castle Formation, Bahramsville Member}

Sand, very fine to fine, silty, clayey, micaceous, yellowish gray

(5Y 7/2) mottled moderate yellowish brown (10YR 7/6) $9-11$

Base of Upper Bacons Castle Formation (Moorings Member): +125 feet elevation

Bottomed in Upper Bacons Castle Formation (Bahramsville Member) 
SC-03-3: 4.27 miles west of the east quadrangle border, 4.59 miles north of the south quadrangle border, southeast $1 / 9^{\text {th }}$ of map area (latitude $36.1647^{\circ} \mathrm{N}$, longitude $77.3757^{\circ} \mathrm{W}$ ). Surface elevation 58 feet.

\section{LITHOLOGY}

DEPTH IN FEET

\section{Chuckatuck Formation}

Sand, very fine to fine, silty, slightly clayey, pale yellowish brown $(10 Y R 6 / 2)$ grading down through yellowish brown $(10 Y R 5 / 2)$ to light olive gray $(5 Y 5 / 2)$ $0-2$

Silt, clayey, very fine sandy, stiff, greenish gray $(5 G Y 6 / 1)$ mottled light brown (5YR 5/6) grading down to dark yellowish orange $(10 Y R 6 / 6)$ in basal foot $2-6$

Sand, fine, silty, contains about $1 \%$ very fine to fine dark heavy mineral grains, grayish orange (10YR 7/4) grading through dusky yellow $(5 Y 6 / 4)$ to yellowish orange $(10 Y R 7 / 6)$ $6-11$

Sand, fine, silty, contains about $1 \%$ very fine to fine dark heavy mineral grains, grayish orange (10YR 7/4) grading at 14 feet to dark grayish orange (10YR 6/4), grades down to $11-16$

Sand, fine to medium, dark yellowish orange (10YR 6/6) grades down to $.16-21$

Sand, medium, yellowish orange (10YR 7/6), grades down to $.21-27$

Sand, fine, slightly silty, slightly micaceous, thixotropic, yellowish orange (10YR 7/6) grading down through grayish yellow (5Y 7/4) (30-33 feet) and through moderate brown (5YR 3/4; 33-34 feet) to dark yellowish orange (10YR 6/8). $.27-36$

Bottomed in Chuckatuck Formation 


\section{UNION QUADRANGLE}

UN-03-1: 1.42 miles west of the east quadrangle border, 8.19 miles north of the south quadrangle border, northeast $1 / 9^{\text {th }}$ of map area (latitude $36.3687^{\circ} \mathrm{N}$, longitude $77.0254^{\circ} \mathrm{W}$ ). Surface elevation 30 feet.

\section{LITHOLOGY}

DEPTH IN FEET

Road fill, sand and gravel $0-1$

\section{Shirley Formation}

Sand, fine to medium, clean, contains very fine to fine dark heavy mineral grains, pale yellowish gray $(5 Y 8 / 2)$ mottled and streaked grayish orange (10YR 7/4) grading down to pale grayish orange $(10 Y R$ 8/4) in basal foot $1-7$

Gravel, round quartz pebbles up to $5 \mathrm{~cm}$ in diameter, pale grayish orange $(10 Y R$ 8/4) $7-8$

\section{Chuckatuck Formation}

Sand, fine to medium, interbedded with sand, very fine to fine, clayey, silty, yellowish orange (10YR 7/6), grades to $8-12$

Sand, medium to coarse, silty, yellowish orange (10YR 7/6) $12-13$

\section{Yorktown Formation (Zone 2)}

Silt, very fine sandy, moderate brown $(5 Y R 4 / 6)$. $.13-14$

Silt, very fine sandy interbedded with sand, very fine, silty, shelly (mostly Mulinia sp., some with luster), medium greenish gray $(5 G 5 / 1)$ $.14-35$

Sand, fine to coarse, modally medium, poorly sorted, shelly with numerous blackened fragments of oysters and Chesapecten sp., medium greenish gray $(5 G 5 / 1)$ $35-40$

\section{Indeterminate Formation}

Spun on hard bed for 20 minutes, no recovery at 40
Base of Shirley Formation:
+22 feet elevation
Base of Chuckatuck Formation:
+17 feet elevation
Base of Yorktown Formation (Zone 2): $\quad-10$ feet elevation

Bottomed on Cape Fear Formation? 
UN-03-2: 5.56 miles west of the east quadrangle border, 7.92 miles north of the south quadrangle border, northwest $1 / 9^{\text {th }}$ of map area (latitude $36.3632^{\circ} \mathrm{N}$, longitude $77.0993^{\circ} \mathrm{W}$ ). Surface elevation 58 feet.

\section{LITHOLOGY}

DEPTH IN FEET

\section{Charles City Formation}

Silt, very fine sandy, slightly clayey, light grayish yellow (5Y 7/4)

mottled dark yellowish orange (10YR 6/6) $0-1$

Silt, very fine sandy, clayey, yellowish gray $(5 Y 7 / 2)$ mottled dark yellowish orange $(10 Y R 6 / 6)$ and moderate brown $(10 Y R 4 / 6)$ grading down at 6 feet to dark yellowish orange $(10 Y R$ 6/6) mottled yellowish gray $(5 Y 7 / 2)$ $.1-14$

Sand, fine to medium, silty, dark yellowish orange (10YR 6/6) grading down to light brown (10YR 5/6) $14-17$

Sand, medium to coarse with scattered round very coarse grains, somewhat thixotropic, dusky yellow $(5 Y 6 / 4)$ grading at 20 feet to light yellowish gray $(5 Y 8 / 2)$. $17-32$

Sand, fine to medium, very silty, dark grayish orange (10YR 6/4) $32-33$

Sand, medium to coarse, silty, clayey, yellowish orange (10YR 7/6) grading rapidly to yellowish orange $(10 Y R$ 6.5/6) ..... $33-36$

Sand, medium to coarse, loose, contains round quartz granules near base, light yellowish gray $(5 Y 8 / 2)$ $36-39$

\section{Yorktown Formation (Zone 2)}

Sand, very fine, silty, clayey, dark yellowish orange (10YR 6/6) mottled moderate brown (5YR 3/4), changes abruptly to $39-39.5$

Sand, very fine, silty, clayey, interbedded with silt, clayey, very fine sandy, contains very fine mica flakes, dark greenish gray $(5 G Y 4 / 1)$. $39.5-63$

Sand, fine to medium with scattered coarse grains, sparse round quartz pebbles up to $2 \mathrm{~cm}$ in diameter at base, dark greenish gray $(5 G Y 4 / 1)$. $63-65$

\section{Indeterminate Formation}

Impenetrable hard bed, no recovery at 65 
Base of Charles City Formation: $\quad+19$ feet elevation

Base of Yorktown Formation (Zone 2): $\quad-7$ feet elevation

Bottomed on Cape Fear Formation? 
UN-03-3: 1.38 miles west of the east quadrangle border, 2.21 miles north of the south quadrangle border, southeast $1 / 9^{\text {th }}$ of map area (latitude $36.2820^{\circ} \mathrm{N}$, longitude $77.0244^{\circ} \mathrm{W}$ ). Surface elevation 63 feet.

\section{LITHOLOGY}

DEPTH IN FEET

\section{Charles City Formation}

Sand, very fine to fine, silty, clayey, dark grayish orange (10YR 6/4) .

$.0-1$

Silt, clayey, very fine sandy, stiff, dark grayish orange (10YR 6/4)

grading through dark yellowish brown $(10 Y R$ 4/6; 2-3 feet) and through light yellowish gray $(5 Y 8 / 2 ; 3-5$ feet) to pale yellowish

brown $(10 Y R 6 / 2)$. $1-7$

Sand, very fine grading down to fine, dark yellowish orange

$(10 Y R$ 6/6) grading down at 9 feet to light yellowish gray

$(5 Y 8 / 2)$ mottled dark yellowish orange (10YR 6/6)

Sand, fine, well sorted, slightly silty, contains less than $1 \%$ very fine to fine dark heavy mineral grains, slightly micaceous, pale grayish orange $(10 Y R$ 8/4) grading down at 23 feet to yellowish orange $(10 Y R 7 / 6)$, grades to..... $11-29$

Sand, medium grading down to medium to coarse, silty, contains sparse round quartz pebbles up to $1 \mathrm{~cm}$ in diameter, yellowish orange $(10 Y R 7 / 6)$ $29-35$

\section{Chowan River Formation}

Sand, very fine, silty, clayey, grading down to silt, clayey, very fine sandy, dark yellowish orange (10YR 5.5/6) in top four inches then goes to medium greenish gray $(5 G 5 / 1)$. $.35-44$

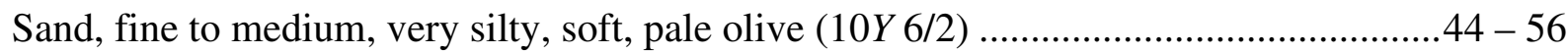

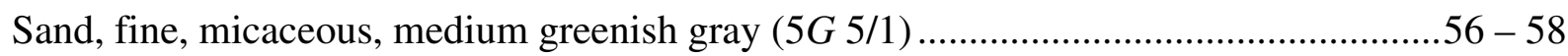

Sand, dominantly very fine but very fine to coarse, silty, medium greenish gray $(5 G Y 5 / 1)$ $.58-60$

Silt, clayey, very fine sandy, finely micaceous, medium olive gray $(5 Y 5 / 1)$ $60-65$

Wood chunk, not carbonized, xylem fairly tough and fibrous, dark yellowish brown $(10 Y R 4 / 4)$ at 65

Silt, clayey, very fine sandy, finely micaceous, dark olive gray $(5 Y 3 / 1)$ grading down to medium greenish gray $(5 G 5 / 1)$ $65-72$ 
Sand, fine to very fine, very silty, soft, dark olive gray $(5 Y 3 / 1) \ldots \ldots \ldots \ldots \ldots \ldots \ldots \ldots \ldots \ldots \ldots \ldots \ldots . . .72-73$

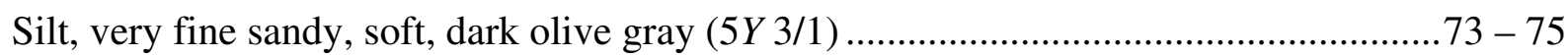

Sand, fine to very fine, very silty, soft, dark olive gray $(5 Y 3 / 1) \ldots \ldots \ldots \ldots \ldots \ldots \ldots \ldots \ldots \ldots \ldots \ldots \ldots \ldots . . .75-76$

Silt, very fine sandy, slightly clayey, micaceous, medium greenish gray $(5 G 5 / 1)$, sparse shells present ............................................................................

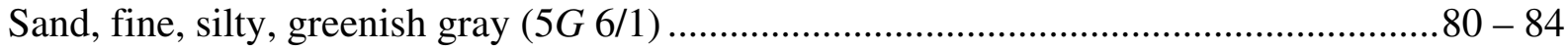

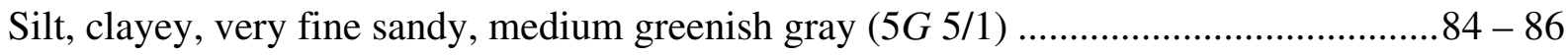

Sand, very fine to fine grading down to fine to medium with scattered coarse and very coarse grains, very silty, soft, subangular to subround quartz pebbles up to $1 \mathrm{~cm}$ in diameter abundant at base, medium greenish gray $(5 G 5 / 1)$ grading through pale olive $(10 Y$ 6/2; 89 - 91 feet) to dark olive gray $(5 Y 3 / 2)$..... $.86-92$

\section{Jericho Run Formation}

Sand, very fine to fine, silty, clayey, micaceous, much denser than above, round quartz pebbles up to $1 \mathrm{~cm}$ in diameter abundant in basal foot, dark olive gray $(5 Y 2 / 2)$.

$.92-95$

\section{Cape Fear Formation}

Sand, fine to medium grading down to fine to very fine, silty, slightly clayey, finely micaceous, dense, pale olive gray (5Y 6/2) $95-101$

$\begin{array}{ll}\text { Base of Charles City Formation: } & +28 \text { feet elevation } \\ \text { Base of Chowan River Formation: } & -29 \text { feet elevation } \\ \text { Base of Jericho Run Formation: } & -32 \text { feet elevation }\end{array}$

Bottomed in Cape Fear Formation 
UN-03-4: 5.87 miles west of the east quadrangle border, 1.85 miles north of the south quadrangle border, southwest $1 / 9^{\text {th }}$ of map area (latitude $36.2769^{\circ} \mathrm{N}$, longitude $77.1048^{\circ} \mathrm{W}$ ). Surface elevation 40 feet.

LITHOLOGY

DEPTH IN FEET

Berm fill, packed sand, silt, and clay

$.0-5$

\section{Alluvium}

Sand, very fine to fine, well sorted, clean, pale yellowish brown $(10 Y R 6 / 2)$ $.5-6$

Sand, medium, soft, pale yellowish gray ( $5 Y$ 8/1) grading down to light olive gray $(5 Y 6 / 1)$ $6-20$

Sand, medium to coarse, slightly silty, granular, loose, light olive gray $(5 Y 6 / 1)$ $.20-24$

\section{Charles City Formation}

Sand, fine to medium grading down to medium to coarse in basal foot, slightly micaceous, pale olive gray $(5 Y 7 / 1)$ grading down to dusky yellow $(5 Y 6 / 4)$ $24-31$

\section{Chowan River Formation}

Silt, clayey, very fine sandy, sticky, wood fragments abundant (roots?), top three inches dark yellowish orange (10YR 6/8) then goes abruptly to greenish gray $(5 G 6 / 1)$ and then grades down to olive gray $(5 Y 4 / 1)$ $31-38$

Sand, very fine to medium, very silty, soft, light olive gray $(5 Y 5 / 2)$ grading down at 40 feet to medium greenish gray $(5 G Y 5 / 1)$ $.38-47$

Silt, clayey, very fine sandy, sticky, medium greenish gray $(5 G Y 5 / 1)$ $47-49$

Sand, very fine to medium grading to fine to medium, very silty, soft, medium greenish gray $(5 G Y 5 / 1)$ grading down to greenish gray $(5 G Y 6 / 1)$ $.49-56$

Sand, medium to coarse, silty, sparse round quartz pebbles coarsen downward from $1 \mathrm{~cm}$ in diameter to $3 \mathrm{~cm}$ in diameter toward the base, greenish gray $(5 G Y 6 / 1)$. $.56-63$

\section{Cape Fear Formation}

Silt, clayey, very fine sandy, stiff, dense, light olive gray $(5 Y 5 / 2)$ with mottles of moderate olive brown $(5 Y 4 / 4)$ in basal foot $.63-66$ 
Base of alluvium: $\quad+16$ feet elevation

Base of Charles City Formation: $\quad+9$ feet elevation

Base of Chowan River Formation: $\quad-23$ feet elevation

Bottomed in Cape Fear Formation 


\section{WELDON OUADRANGLE}

WE-02-1: 1.99 miles west of the east quadrangle border, 4.80 miles north of the south quadrangle border, east-central $1 / 9^{\text {th }}$ of map area (latitude $36.4447^{\circ} \mathrm{N}$, longitude $77.5335^{\circ} \mathrm{W}$ ). Surface elevation 114 feet.

\section{LITHOLOGY}

DEPTH IN FEET

Road fill $0-1$

\section{Upper Bacons Castle Formation, Bahramsville Member}

Sand, medium to very coarse, contains abundant round quartz pebbles

up to $3 \mathrm{~cm}$ in diameter, micaceous, dark brownish gray $(5 Y R 3 / 1)$ $1-4$

Sand, medium to very coarse, clayey, silty, contains sparse round quartz pebbles up to $3 \mathrm{~cm}$ in diameter, micaceous, olive $(10 Y 5 / 2)$ $4-6$

Sand, medium to very coarse grading down to coarse to very coarse, contains sparse round quartz pebbles up to $5 \mathrm{~cm}$ in diameter, micaceous, yellowish gray $(5 Y 7 / 2)$. $6-13$

Gravel, round quartz pebbles up to $8 \mathrm{~cm}$ in diameter, coarse to very coarse quartz sand matrix, slightly silty, slightly clayey, grayish orange $(10 Y R 7 / 4)$ $13-25$

\section{Lower Bacons Castle Formation, Varina Grove Member}

Sand, fine to medium, well sorted, subangular to subround, slightly silty, contains $2-5 \%$ very fine to fine dark heavy mineral grains, fine to very coarse size mica, dark yellowish orange $(10 Y R 6 / 6)$ in top foot grading rapidly to pale grayish orange (10YR 8/4).... $.25-32$

Gravel, round quartz pebbles and discoids up to $8 \mathrm{~cm}$ in diameter, coarse to very coarse quartz sand matrix, pale grayish orange

\section{Yorktown Formation (Zone 2)}

Silt, very fine sandy, dark yellowish orange (10YR 5/6) $33-36$

Silt, very fine sandy interbedded with sand, very fine, silty, very fine mica present, dark greenish gray $(5 Y 4 / 1)$, grades rapidly to $.36-48$

Sand, very fine to fine, slightly micaceous, contains scattered round medium and coarse grains, coarsens by base to fine to medium and silty, dark greenish gray $(5 Y 4 / 1)$ $48-56$ 
Sand, medium to coarse, shelly, abundant round quartz pebbles up to $4 \mathrm{~cm}$ in diameter in basal foot, medium greenish gray $(5 G 5 / 1)$

except for basal two inches which are dark olive gray $(5 Y 3 / 1)$....

$.56-66$

\section{Clubhouse Formation}

Sand, very fine, silty, clayey, stiff, dense, medium greenish gray

$(5 G 5 / 1)$, grades to

$66-70$

Silt, very clayey, very fine sandy, very stiff, dense, moderate brown

$(5 Y R$ 4/6) mottled medium olive gray $(5 Y 5 / 1)$

$70-76$

Base of Upper Bacons Castle Formation (Bahramsville Member): $\quad+89$ feet elevation

Base of Lower Bacons Castle Formation (Varina Grove Member): $\quad+81$ feet elevation

Base of Yorktown Formation (Zone 2):

+48 feet elevation

Bottomed in Clubhouse Formation 
WE-02-2: 3.92 miles west of the east quadrangle border, 4.79 miles north of the south quadrangle border, central $1 / 9^{\text {th }}$ of map area (latitude $36.4446^{\circ} \mathrm{N}$, longitude $77.5700^{\circ} \mathrm{W}$ ). Surface elevation 155 feet.

\section{LITHOLOGY}

DEPTH IN FEET

\section{Lower Bacons Castle Formation, Varina Grove Member}

Sand, fine to coarse, subround to round, loose, dark yellowish brown $(10 Y R 4 / 2)$ grading through yellowish orange (10YR 7/6) to moderate reddish brown $(10 R 4 / 6)$ $.0-1$

Sand, fine to coarse, silty, clayey, stiff, moderate reddish brown $(10 R$ 4/6), grades to. $.1-11$

Sand, medium to very coarse grading down to fine to coarse, poorly sorted; contains subangular to subround quartz pebbles up to $2 \mathrm{~cm}$ in diameter, moderate brown ( $5 Y R 4 / 6)$, grades to $11-25$

Sand, fine to medium, silty, contains sparse subround quartz pebbles up to $2 \mathrm{~cm}$ in diameter and $2-5 \%$ very fine to fine dark heavy mineral grains, slightly micaceous, yellowish orange (10YR 7/6). $25-36$

Sand, fine to medium, silty, dark grayish orange (10YR 6/4), grades to $.36-47$

Sand, medium to very coarse, contains sparse subround quartz pebbles up to $2 \mathrm{~cm}$ in diameter, dark grayish orange (10YR 6/4) $.47-50$

Gravel, subround quartz pebbles up to $2 \mathrm{~cm}$ in diameter, coarse to very coarse sand matrix, dark grayish orange (10YR 6/4), tough drilling $.50-53$

\section{Chowan River Formation}

Sand, fine to coarse, contains abundant round quartz pebbles at base up to $5 \mathrm{~cm}$ in diameter, pale yellowish gray $(5 Y 8 / 2)$ grading down to yellowish gray $(5 Y 7 / 2)$ $.53-63$

\section{Yorktown Formation (Zone 2)}

Silt, very fine sandy, clayey, finely micaceous, very dark orange (10YR 5/6), grades to. $.63-65$

Silt, very fine sandy, clayey, finely micaceous, shelly, medium greenish gray $(5 \mathrm{G} 5 / 1)$, grades to $65-76$

Sand, very fine, shelly (including Chesapecten sp.), medium greenish gray $(5 G 5 / 1)$ $.76-84$ 
Gravel, round quartz pebbles up to $2.5 \mathrm{~cm}$ in diameter, medium greenish gray $(5 G 5 / 1)$......

\section{Eastern Carolina Slate Belt Rocks}

Saprolite, clayey silt, contains angular fine to medium quartz grains, abundant kaolinite, much denser than above, light yellowish gray $(5 Y 8 / 2)$, grades rapidly to. $.85-90$

Saprolite, clayey silt, contains about $25 \%$ angular medium to coarse quartz grains, pale reddish brown $(10 R 5 / 6)$ $90-96$

Base of Lower Bacons Castle Formation (Varina Grove Member): Base of Chowan River Formation:

Base of Yorktown Formation (Zone 2):

+102 feet elevation +92 feet elevation +70 feet elevation

Bottomed in Eastern Carolina Slate Belt saprolite 
WE-02-3: 6.08 miles west of the east quadrangle border, 6.41 miles north of the south quadrangle border, northwest $1 / 9^{\text {th }}$ of map area (latitude $36.4680^{\circ} \mathrm{N}$, longitude $77.6085^{\circ} \mathrm{W}$ ). Surface elevation 124 feet.

\section{LITHOLOGY}

DEPTH IN FEET

\section{Upper Bacons Castle Formation, Bahramsville Member}

Sand, dominantly very fine to fine but ranging up to very coarse, larger grains subangular, silty, clayey, dark yellowish brown $(10 Y R 4 / 2)$ $0-1$

Sand, dominantly very fine to fine but ranging up to very coarse, larger grains subangular, silty, clayey, micaceous, pale yellowish brown (10YR 5.5/2) mottled light olive brown (5Y 5/4) grading down at 6 feet to light greenish gray $(5 G 7 / 1)$, grades very rapidly to $1-10$

Sand, dominantly very fine to fine but ranging up to very coarse, larger grains subangular, silty, loose, light olive brown $(5 Y 5 / 4)$.... $10-14$

Sand, medium to coarse, poorly sorted, silty, grading down to coarse to very coarse, contains abundant round quartz pebbles up to $2.5 \mathrm{~cm}$ in diameter, dark yellowish orange $(10 Y R \mathrm{~K} / 6)$ $14-19$

Gravel, round to discoidal quartz pebbles up to $7 \mathrm{~cm}$ in diameter, dusky brown $(5 Y R 2 / 2)$ to moderate grayish brown $(5 Y R 4 / 2)$, in pale grayish orange $(10 Y R 8 / 2)$ clayey sand matrix. $.19-28$

\section{Eastern Carolina Slate Belt Rocks}

Saprolite, clayey silt, contains abundant angular coarse quartz grains, very micaceous, dark yellowish orange (10YR 6/6) with streaks of light gray $(N 8)$ grading down to very dark yellowish orange $(10 Y R 5 / 6)$ $.28-31$

Base of Upper Bacons Castle Formation (Bahramsville Member): +96 feet elevation

Bottomed in Eastern Carolina Slate Belt saprolite 
WE-02-4: 1.89 miles west of the east quadrangle border, 2.42 miles north of the south quadrangle border, southeast $1 / 9^{\text {th }}$ of map area (latitude $36.4102^{\circ} \mathrm{N}$, longitude $77.5335^{\circ} \mathrm{W}$ ). Surface elevation 98 feet.

\section{LITHOLOGY}

DEPTH IN FEET

\section{Windsor Formation}

Sand, dominantly very fine, ranging up to medium, silty, clayey, stiff, pale olive brown $(5 Y 6 / 6)$, grades to $0-1$

Sand, dominantly fine, ranges from very fine to medium, silty, grayish orange (10YR 7/4) mottled dark yellowish orange (10YR 6/6), grades to $1-6$

Sand, fine, well sorted, silty, contains $1-2 \%$ very fine to fine dark heavy mineral grains, yellowish orange (10YR 7/6), grades rapidly to. $6-12$

Sand, very fine, silty, clayey, grading down to silt, clayey, very fine sandy, micaceous, dark yellowish orange (10YR 6/6) mottled light yellowish gray (5Y 7/2) grading down to dusky yellow (5Y 6/4) mottled dark yellowish orange (10YR 6/6) $.12-21$

Sand, fine to coarse, poorly sorted, grading down to coarse to very coarse, subangular, feldspathic, silty, moderate yellowish brown (10YR 5/4) $21-38$

Gravel, round quartz pebbles up to $5 \mathrm{~cm}$ in diameter, grayish orange $(10 Y R 7 / 4)$ $.38-45$

\section{Yorktown Formation (Zone 2)}

Sand, fine, well sorted dark yellowish orange (10YR 6/6) grading rapidly down to light yellowish brown (10YR 6/4), grades to $45-48$

Sand, fine, coarsely micaceous, shelly, contains lumps of phosphate, medium greenish gray $(5 G 5 / 1)$ $48-53$

\section{Clubhouse Formation}

Silt, very clayey, very fine to medium sandy, micaceous, stiff, olive gray $(5 Y 4 / 1)$ grading through dark brownish gray $(5 Y R 3 / 1)$ to medium greenish gray (5GY 5/1) mottled brownish gray (5YR 4/1) $.53-71$

$\begin{array}{ll}\text { Base of Windsor Formation: } & +53 \text { feet elevation } \\ \text { Base of Yorktown Formation (Zone 2): } & +45 \text { feet elevation }\end{array}$

Bottomed in Clubhouse Formation 
WE-02-5: 6.37 miles west of the east quadrangle border, 0.32 miles north of the south quadrangle border, southwest $1 / 9^{\text {th }}$ of map area (latitude $36.3797^{\circ} \mathrm{N}$, longitude $77.6142^{\circ} \mathrm{W}$ ). Surface elevation 133 feet.

\section{LITHOLOGY}

DEPTH IN FEET

\section{Lower Bacons Castle Formation, Varina Grove Member}

Sand, medium to coarse, subangular, clean, very dark yellowish

brown $(10 Y R 3 / 2)$ grading down to yellowish gray $(5 Y 7 / 2)$ $.0-1$

Silt, clayey, very fine to fine sandy, grading down to sand, very fine to fine, silty, clayey, micaceous, stiff, dark yellowish orange (10YR 6/6) mottled yellowish gray (5Y 7/2) grading down to yellowish gray $(5 Y 7 / 2)$ mottled dark yellowish orange $(10 Y R 6 / 6)$, grades rapidly to. $1-15$

Sand, fine, well sorted, silty, contains $1-2 \%$ very fine to fine dark heavy mineral grains, yellowish gray $(5 Y 7 / 2)$ mottled dark yellowish orange (10YR 6/6), grades to.... $15-30$

Sand, fine to medium, silty, very dark yellowish orange $(10 Y R 5 / 6)$. $30-36$

Sand, medium to very coarse, contains abundant subround to round quartz pebbles up to $2.5 \mathrm{~cm}$ in diameter, very dark yellowish orange $(10 Y R$ 5/6) $.36-39$

\section{Yorktown Formation (Zone 2)}

Silt, very fine sandy, clayey, finely micaceous, upper foot light olive brown ( $5 Y 5 / 4)$ then grades rapidly to dark greenish gray $(5 G 4 / 1)$. $.39-46$

Base of Lower Bacons Castle Formation (Varina Grove Member): +94 feet elevation

Bottomed in Yorktown Formation (Zone 2) 
WE-02-6: 5.83 miles west of the east quadrangle border, 2.01 miles north of the south quadrangle border, southwest $1 / 9^{\text {th }}$ of map area (latitude $36.4040^{\circ} \mathrm{N}$, longitude $77.6042^{\circ} \mathrm{W}$ ). Surface elevation 115 feet.

\section{LITHOLOGY}

DEPTH IN FEET

\section{Upper Bacons Castle Formation, Bahramsville Member}

Sand, dominantly medium, ranging up to very coarse, contains scattered round quartz pebbles up to $1 \mathrm{~cm}$ in diameter, dark yellowish brown $(10 Y R 4 / 2)$ grading down to dark yellowish orange (10YR 6/6) $.0-1$

Sand, dominantly medium, ranging up to very coarse, light brown $(5 Y R$ 5/6)................ $1-6$

Sand, medium to very coarse, subangular, silty, contains abundant round quartz pebbles up to $2.5 \mathrm{~cm}$ in diameter, yellowish orange $(10 Y R 7 / 6)$ $6-20$

Gravel, round quartz clasts up to $5 \mathrm{~cm}$ in diameter, coarse to very coarse sand matrix, yellowish orange $(10 Y R 7 / 6)$ $.20-27$

\section{Yorktown Formation (Zone 2)}

Silt, very fine sandy, clayey, light olive brown (5Y 5/4) grading through medium greenish gray $(5 G Y 5 / 1)$ to moderate reddish brown $(10 R 4 / 6)$ $27-29$

Sand, very fine, silty, clayey, medium greenish gray $(5 G Y 5 / 1)$ $.29-38$

Sand, fine to medium, silty, contains chalky shells, black-stained round quartz pebbles up to $2.5 \mathrm{~cm}$ in diameter, and a phosphatized clam cast $8 \mathrm{~cm}$ long, medium greenish gray $(5 G Y 5 / 1)$ $38-40$

\section{Eastern Carolina Slate Belt Rocks}

Saprolite, quartz, coarse to very coarse, angular, in 50\% clayey silt matrix, very pale brown $(5 Y R 6 / 2)$, much denser than above $40-46$

\section{Base of Upper Bacons Castle Formation (Bahramsville Member): $\quad+88$ feet elevation Base of Yorktown Formation (Zone 2): +75 feet elevation}

Bottomed in Eastern Carolina Slate Belt saprolite 


\section{WHITAKERS QUADRANGLE}

WH-03-1: 3.49 miles west of the east quadrangle border, 5.79 miles north of the south quadrangle border, on boundary between the central and north-central $1 / 9^{\text {ths }}$ of map area (latitude $36.0841^{\circ} \mathrm{N}$, longitude $77.6867^{\circ} \mathrm{W}$ ). Surface elevation 120 feet.

\section{LITHOLOGY}

DEPTH IN FEET

\section{Upper Bacons Castle Formation, Bahramsville Member}

Sand, fine to medium, silty, clayey, yellowish brown (10YR 5/2) grading down to dusky yellow $(5 Y 6 / 4)$..... $0-1$

Sand, fine to medium, silty, clayey, pale olive brown $(5 Y 6 / 6)$, grades to $1-2$

Sand, fine to medium, silty, clayey, yellowish gray (5Y 7/2) mottled pale olive brown $(5 Y 6 / 6)$, grades to $2-4$

Sand, fine to medium, silty, clayey, reddish brown $(10 R 6 / 6)$ mottled yellowish gray $(5 Y 7 / 2)$, grades to $4-5$

Sand, fine to medium, silty, clayey, dark yellowish orange $(10 Y R 6 / 6)$ $5-8$

Silt, very fine sandy, clayey, stiff, yellowish gray (5Y 7/2) grading down to medium greenish gray $(5 G Y 6 / 1)$ $8-15$

Sand, very fine to medium, silty, thixotropic, grading rapidly down to medium to very coarse, subangular, subround quartz pebbles up to $3 \mathrm{~cm}$ in diameter abundant in basal 3 feet, grayish yellow (5Y 7/4) throughout $15-25$

\section{Yorktown Formation (Zone 2)}

Silt, very fine sandy, clayey, medium greenish gray $(5 G 5 / 1)$ $.25-49$

Sand, very fine, silty, clayey, sparsely shelly, grading down to sand, fine, silty, clayey, very shelly, medium greenish gray $(5 G 5 / 1)$.... $49-75$

\section{Clubhouse Formation}

Sand, dominantly fine but contains scattered grains up to coarse, silty, variably clayey, micaceous, dense, tough drilling, brownish gray $(5 Y R$ 4/1) interbedded with medium brownish gray $(5 Y R 5 / 1)$ going to moderate reddish brown $(10 R 4 / 6)$ in basal foot $.75-81$

$\begin{array}{ll}\text { Base of Upper Bacons Castle Formation (Bahramsville Member): } & +95 \text { feet elevation } \\ \text { Base of Yorktown Formation (Zone 2): } & +45 \text { feet elevation }\end{array}$

Bottomed in Clubhouse Formation 
WH-03-2: 4.13 miles west of the east quadrangle border, 1.88 miles north of the south quadrangle border, south-central $1 / 9^{\text {th }}$ of map area (latitude $36.0272^{\circ} \mathrm{N}$, longitude $77.6982^{\circ} \mathrm{W}$ ). Surface elevation 117 feet.

\section{LITHOLOGY}

DEPTH IN FEET

\section{Upper Bacons Castle Formation, Bahramsville Member}

Sand, fine to sparse medium, silty, grayish yellow (5Y 7/4). $0-1$

Sand, fine to medium grading down to medium to coarse, subangular, silty, slightly clayey, yellowish orange $(10 Y R 7 / 6)$ $1-6$

Sand, medium to coarse, subangular, silty, pale brown $(5 Y R 6 / 6)$ grading down to yellowish orange (10YR 7/6), grades to $6-11$

Sand, medium to coarse, subangular, silty, dark grayish orange (10YR 6/4) $11-14$

Sand, fine to very coarse, very poorly sorted, angular to subangular, silty, clayey, yellowish orange (10YR 7/6) interbedded with sand, very fine, silty, clayey, yellowish gray $(5 Y 7 / 2)$ $.14-21$

Silt, very fine sandy, very clayey, yellowish gray (5Y 7/2) $.21-24$

\section{Yorktown Formation (Zone 2)}

Sand, very fine, silty, contains burrows filled with clayey silt from above, dark yellowish orange $(10 Y R$ 6/6) $24-26$

Silt, very fine sandy, clayey, medium greenish gray $(5 G 5 / 1)$, grades to .............................. 40

Sand, very fine, silty, clayey, medium greenish gray $(5 G 5 / 1)$, grades to .......................40 - 49

Sand, fine, silty, shelly, medium greenish gray $(5 G 5 / 1)$, grades to $.49-71$

Sand, fine, silty, clayey, shelly, round black-stained quartz pebbles up to $4 \mathrm{~cm}$ in diameter present at base, medium greenish gray $(5 G 5 / 1)$ $71-74$

\section{Clubhouse Formation}

Sand, very fine but with scattered grains up to medium, angular to subangular, silty, clayey, much denser than above, contains coarse mica flakes, moderate olive gray $(5 Y 5 / 1)$ grading through dusky yellow $(5 Y 6 / 4 ; 77-79$ feet) to moderate olive brown $(5 Y 4 / 4)$ mottled light greenish gray $(5 G 7 / 1)$ $.74-81$ 
Base of Upper Bacons Castle Formation (Bahramsville Member): $\quad$ +93 feet elevation Base of Yorktown Formation (Zone 2): +43 feet elevation

Bottomed in Clubhouse Formation 


\section{WOODLAND QUADRANGLE}

WL-03-1: 2.77 miles west of the east quadrangle border, 8.31 miles north of the south quadrangle border, north-central $1 / 9^{\text {th }}$ of map area (latitude $36.3705^{\circ} \mathrm{N}$, longitude $77.1741^{\circ} \mathrm{W}$ ). Surface elevation 38 feet.

\section{LITHOLOGY}

DEPTH IN FEET

\section{Shirley Formation}

Sand, fine, well sorted, clean, contains about $1 \%$ very fine to fine dark heavy mineral grains, light grayish orange (10YR 8/4) grading down to light yellowish gray $(5 Y 8 / 2)$ $0-6$

Sand, dominantly medium but fine to coarse, poorly sorted, clean, grading down through coarse to very coarse to medium to coarse and pebbly, round quartz pebbles up to $1 \mathrm{~cm}$ in diameter, yellowish gray $(5 Y 7 / 2)$ grading down at 14 feet to pale yellowish brown $(10 Y R 6 / 2)$ $6-16$

\section{Chowan River Formation}

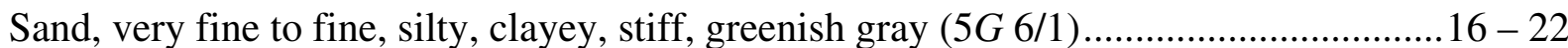

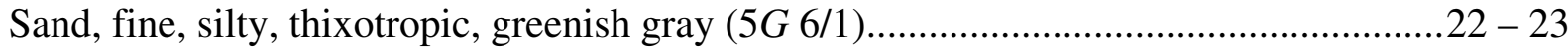

Silt, clayey, very fine sandy, contains wood fragment, stiff, greenish gray $(5 G Y 6 / 1)$ $.23-26$

Auger jammed at bottom and had to be unscrewed, soft drilling to 67 feet, sparse recovery indicates thixotropic sand grading down from very fine to fine and very silty to coarse to very coarse and pebbly $26-67$

No recovery, crunchy drilling through this interval suggests gravel $67-77$

\section{Cape Fear Formation?}

No recovery, very tough drilling, this interval swelled and jammed suggesting Cape Fear clay $.77-86$

Base of Shirley Formation: $\quad+22$ feet elevation

Base of Chowan River Formation: $\quad-39$ feet elevation

Bottomed in Cape Fear Formation? 
WL-03-2: 3.80 miles west of the east quadrangle border, 1.06 miles north of the south quadrangle border, south-central $1 / 9^{\text {th }}$ of map area (latitude $36.2653^{\circ} \mathrm{N}$, longitude $77.1944^{\circ} \mathrm{W}$ ). Surface elevation 64 feet.

\section{LITHOLOGY}

DEPTH IN FEET

\section{Charles City Formation}

Silt, clayey, very fine sandy, stiff, moderate brown (5YR 5/4) grading down to dark yellowish orange (10YR 6/6) $0-1$

Silt, clayey, very fine sandy, stiff, yellowish gray (5Y 7/2) mottled dark yellowish orange $(10 Y R 6 / 6)$, grades to $1-6$

Silt, clayey, very fine sandy, stiff, yellowish gray $(5 Y 7 / 2)$ mottled dark yellowish orange (10YR 6/6) and dark yellowish brown (10YR 4/6) $6-11$

Silt, clayey, very fine sandy, stiff, dark yellowish brown $(10 Y R 4 / 6)$

mottled dark yellowish orange $(10 Y R 6 / 6)$ and greenish gray $(5 G 6 / 1)$ $11-16$

Sand, fine grading down to fine to medium, silty, clayey, light olive brown $(5 Y 5 / 4)$ $16-18$

Sand, fine to coarse, poorly sorted, clean, thixotropic, very soft, medium olive (10Y 4/4) grading down at 24 feet to light greenish gray $(5 G Y 7 / 1)$ $18-37$

Sand, coarse to very coarse, contains abundant round quartz granules and pebbles up to $1 \mathrm{~cm}$ in diameter light greenish gray $(5 G Y 7 / 1) \ldots$ $.37-38$

\section{Cape Fear Formation}

Silt, clayey, very fine to medium sandy, dense, micaceous, medium greenish gray $(5 G Y 5 / 1)$ mottled moderate olive brown $(5 Y 4 / 4)$ grading down to moderate olive brown $(5 Y$ 4/4) mottled medium greenish gray $(5 G Y 5 / 1)$, breaks up into small lumps $38-46$

Base of Charles City Formation: +26 feet elevation

Bottomed in Cape Fear Formation 


\section{WOODVILLE QUADRANGLE}

WV-02-1: 4.03 miles west of the east quadrangle border, 1.09 miles north of the south quadrangle border, south-central $1 / 9^{\text {th }}$ of map area (latitude $36.0159^{\circ} \mathrm{N}$, longitude $77.1963^{\circ} \mathrm{W}$ ). Surface elevation 22 feet.

\section{LITHOLOGY}

DEPTH IN FEET

\section{Alluvium}

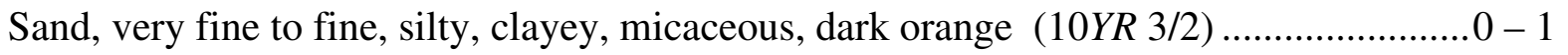

Sand, very fine to fine grading down to fine to medium, silty, thixotropic, contains abundant dark carbonaceous? specks, dark grayish orange

(10YR 6/4), grades to $1-6$

Sand, medium to coarse, contains abundant subround quartz pebbles up

to $1 \mathrm{~cm}$ in diameter, moderate yellowish brown $(10 Y R 5 / 4)$ $6-14$

\section{Yorktown Formation}

Sand, fine to medium, silty, clayey, micaceous, medium greenish gray $(5 G 5 / 1)$, grades to $14-20$

Sand, fine to medium, silty, clayey, micaceous, shelly (including pectenids, scaphopods, etc.), medium greenish gray $(5 G 5 / 1)$ $20-28$

\section{Tar Heel Formation}

Sand, very fine, silty, clayey, micaceous, moderate olive gray $(5 Y 5 / 1)$ $28-41$

Sand, fine to coarse, medium to coarse grains subround, silty, contains sparse round quartz pebbles up to $1 \mathrm{~cm}$ in diameter, moderate olive gray $(5 Y 5 / 1)$ $.41-53$

Sand, fine to coarse, medium to coarse grains subround, silty, clayey, contains abundant round quartz pebbles up to $2 \mathrm{~cm}$ in diameter, moderate olive gray $(5 Y 5 / 1)$ $.53-56$

\section{Cape Fear Formation}

Sand, fine to coarse, very clayey, very dense, tough drilling, dark reddish brown (10R 3/4) mottled medium olive gray $(5 Y 5 / 1)$. $.56-66$

Base of alluvium:

Yorktown Formation (Zone 2):

Base of Tar Heel Formation:
+8 feet elevation

-6 feet elevation

-34 feet elevation

Bottomed in Cape Fear Formation 
WV-02-2: 3.69 miles west of the east quadrangle border, 6.47 miles north of the south quadrangle border, north-central $1 / 9^{\text {th }}$ of map area (latitude $36.0936^{\circ} \mathrm{N}$, longitude $77.1904^{\circ} \mathrm{W}$ ). Surface elevation 47 feet.

\section{LITHOLOGY}

DEPTH IN FEET

\section{Chuckatuck Formation}

Sand, very fine, silty, clayey, micaceous, dusky yellowish brown

(10YR 2/2) grading down to light olive gray $(5 Y 5 / 2)$

$0-1$

Silt, very fine sandy, clayey, micaceous, light olive gray $(5 Y 5 / 2)$

mottled moderate orange $(10 Y R 3 / 6)$

$1-12$

Sand, fine to medium grading down to medium to coarse, yellowish

gray $(5 Y 7 / 2)$ grading through dark orange (10YR 2/6; 17-19 feet) back

to yellowish gray $(5 Y 7 / 2)$

Sand, fine, well sorted, contains about $1-2 \%$ very fine to fine dark heavy

mineral grains, silty, soft, dark yellowish orange (10YR 6/6) grading

around 37 feet to olive $(10 Y 5 / 2)$

$.21-40$

Sand, fine to medium grading down to medium to coarse, subangular,

medium brownish gray $(10 Y R$ 5/1) $40-50$

Sand, medium to coarse, contains round quartz and phosphate pebbles up to $2 \mathrm{~cm}$ in diameter and a pebble of slate belt rock $4 \mathrm{~cm}$ in diameter, medium brownish gray $(10 Y R$ 5/1). $.50-51$

\section{Cape Fear Formation}

Sand, very fine to fine, micaceous, silty, dense, tough drilling, medium greenish gray $(5 G 5 / 1)$ grading down to olive gray $(5 Y 4 / 1)$..... $.51-66$

Base of Chuckatuck Formation: -4 feet elevation

Bottomed in Cape Fear Formation 
WV-02-3: 3.68 miles west of the east quadrangle border, 7.64 miles north of the south quadrangle border, north-central $1 / 9^{\text {th }}$ of map area (latitude $36.1108^{\circ} \mathrm{N}$, longitude $77.1911^{\circ} \mathrm{W}$ ). Surface elevation 75 feet.

\section{LITHOLOGY}

DEPTH IN FEET

\section{Windsor Formation}

Sand, fine to medium, silty, clayey, stiff, dark yellowish orange

(10YR 6/6) grading down at 1 foot to dark yellowish orange

(10YR 6/6) mottled yellowish gray $(5 Y 7 / 2)$ and reddish orange

$(10 R 5 / 6)$

Sand, medium to coarse, silty, loose, yellowish orange $(10 Y R$ 5/6) .............................11 - 22

\section{Yorktown Formation (Zone 2)}

Sand, very fine, silty, clayey, interbedded with silt, very fine sandy and clayey, greenish gray $(5 G Y 5 / 1)$ $.22-46$

Base of Windsor Formation: +53 feet elevation

Bottomed in Yorktown Formation (Zone 2) 


\section{SUPPLEMENTARY BASEMENT DATA}

\begin{tabular}{|c|c|c|c|c|}
\hline $\begin{array}{l}\text { Basement elevation } \\
\text { (in feet) }\end{array}$ & Latitude & Longitude & Well Name & Data Source \\
\hline-182 & $36.3011 \mathrm{~N}$ & $77.4367 \mathrm{~W}$ & Well Number 341 & Trapp (1992), p. G57 \\
\hline-212 & $36.3362 \mathrm{~N}$ & $77.4319 \mathrm{~W}$ & NC-NOR-T-12 & $\begin{array}{c}\text { Brown and others (1972) } \\
\text { Plate } 29\end{array}$ \\
\hline-230 & $36.1000 \mathrm{~N}$ & $77.5125 \mathrm{~W}$ & HA-P-1-79 & $\begin{array}{c}\text { North Carolina Geological } \\
\text { Survey geophysical } \\
\text { database }^{1}\end{array}$ \\
\hline-244 & $36.1154 \mathrm{~N}$ & $77.3763 \mathrm{~W}$ & NC-HAL-T-2 & $\begin{array}{c}\text { Brown and others (1972) } \\
\text { Plate } 43\end{array}$ \\
\hline-245 & $36.1268 \mathrm{~N}$ & $77.4116 \mathrm{~W}$ & Well Number 345 & Trapp (1992), p. G57 \\
\hline-282 & $36.0581 \mathrm{~N}$ & $77.4206 \mathrm{~W}$ & HA-T-1-85 & $\begin{array}{c}\text { North Carolina Geological } \\
\text { Survey geophysical } \\
\text { database }\end{array}$ \\
\hline-306 & $36.0300 \mathrm{~N}$ & $77.3972 \mathrm{~W}$ & NC-HAL-T-16 & $\begin{array}{c}\text { Brown and others (1972) } \\
\text { Plate } 43\end{array}$ \\
\hline-415 & $36.4342 \mathrm{~N}$ & $77.2275 \mathrm{~W}$ & Well Number 335 & Trapp (1992), p. G57 \\
\hline-561 & $36.4374 \mathrm{~N}$ & $77.0944 \mathrm{~W}$ & NC-HE-P-12 & $\begin{array}{c}\text { Brown and others (1972) } \\
\text { Plate } 46\end{array}$ \\
\hline-592 & $36.0517 \mathrm{~N}$ & $77.1945 \mathrm{~W}$ & BT-T-1-82 & $\begin{array}{c}\text { North Carolina Geological } \\
\text { Survey geophysical } \\
\text { database }^{1}\end{array}$ \\
\hline$<-595$ & $36.2388 \mathrm{~N}$ & $77.1870 \mathrm{~W}$ & EHNR Roxobel & $\begin{array}{l}\text { NC DENR, Division of } \\
\text { Water Resources }\end{array}$ \\
\hline-978 & $36.0329 \mathrm{~N}$ & $77.0192 \mathrm{~W}$ & BE-110-2004 & USGS/NCGS core hole \\
\hline
\end{tabular}

${ }^{1}$ Website located at:

http://www.ncwater.org/Data_and_Modeling/Ground_Water_Databases/ 